\title{
MINERALS FROM MACEDONIA. XXX. COMPLEMENTARY USE OF VIBRATIONAL SPECTROSCOPY AND X-RAY POWDER DIFFRACTION FOR SPECTRA-STRUCTURAL STUDY OF SOME CYCLO-, PHYLLO- AND TECTOSILICATE MINERALS. A REVIEW
}

\author{
Gligor Jovanovski ${ }^{1,2^{*}}$, Petre Makreski ${ }^{2 *}$ \\ ${ }^{1}$ Research Center for Environment and Materials, Macedonian Academy of Sciences and Arts, \\ Krste Misirkov 2, 1000 Skopje, Republic of Macedonia \\ ${ }^{2}$ Institute of Chemistry, Faculty of Natural Sciences and Mathematics, Ss. Cyril and Methodius University, \\ Arhimedova 5, 1000 Skopje, Republic of Macedonia \\ gligor@pmf.ukim.mk; petremak@pmf.ukim.mk
}

A review of the results of the complementary use of vibrational spectroscopy (infrared and Raman) and X-ray powder diffraction in the process of identification and spectra-structure correlation of some cyclo-, phyllo- and tectosilicate minerals originating from the Republic of Macedonia is presented. The following minerals are studied: schorl, $\mathrm{Na}\left(\mathrm{Fe}^{2+}, \mathrm{Mg}\right)_{3} \mathrm{Al}_{6}\left(\mathrm{BO}_{3}\right)_{3} \mathrm{Si}_{6} \mathrm{O}_{18}(\mathrm{OH})_{4}$; beryl, $(\mathrm{Be}, \mathrm{Mg})_{3} \mathrm{Al}_{2} \mathrm{Si}_{6} \mathrm{O}_{18} ; \quad$ chrysotile, $\mathrm{Mg}_{3} \mathrm{Si}_{2} \mathrm{O}_{5}(\mathrm{OH})_{4} ; \quad$ antigorite, $\left(\mathrm{Mg}_{2} \mathrm{Fe}^{2+}\right)_{3} \mathrm{Si}_{2} \mathrm{O}_{5}(\mathrm{OH})_{4} ; \quad$ talc, $\left(\mathrm{Mg}, \mathrm{Fe}^{2+}\right)_{3} \mathrm{Si}_{4} \mathrm{O}_{10}(\mathrm{OH})_{2}$; clinochlore, $\left(\mathrm{Mg}, \mathrm{Fe}^{2+}\right)_{5} \mathrm{Si}_{3}(\mathrm{Al}, \mathrm{Cr})_{2} \mathrm{O}_{10}(\mathrm{OH})_{8}$; cymrite, $\mathrm{BaAl}_{2} \mathrm{Si}_{2} \mathrm{O}_{8} \cdot \mathrm{H}_{2} \mathrm{O}$; montmorillonite, $\quad(\mathrm{K}, \mathrm{Ca})_{0.3}\left(\mathrm{Al}, \mathrm{Mg}_{2} \mathrm{Si}_{4} \mathrm{O}_{10}(\mathrm{OH})_{2} \cdot \mathrm{nH}_{2} \mathrm{O} ; \quad\right.$ muscovite, $\mathrm{KAl}_{2}\left(\mathrm{Si}_{3} \mathrm{Al}\right) \mathrm{O}_{10}(\mathrm{OH}, \mathrm{F})_{2} ; \quad$ phlogopite, $\mathrm{KMg}_{3}\left(\mathrm{Si}_{3} \mathrm{Al}\right) \mathrm{O}_{10}(\mathrm{OH}, \mathrm{F})_{2}$; biotite, $\mathrm{K}\left(\mathrm{Mg}, \mathrm{Fe}^{2+}\right)_{3} \mathrm{AlSi}_{3} \mathrm{O}_{10}(\mathrm{OH}, \mathrm{F})_{2}$; sheridanite, $(\mathrm{Mg}, \mathrm{Al})_{6}(\mathrm{Si}, \mathrm{Al})_{4} \mathrm{O}_{10}(\mathrm{OH})_{8}$; albite, $\mathrm{NaAlSi}_{3} \mathrm{O}_{8}$; microcline, $\mathrm{KAlSi}_{3} \mathrm{O}_{8}$; sanidine, $(\mathrm{K}, \mathrm{Na})(\mathrm{Si}, \mathrm{Al})_{4} \mathrm{O}_{8}$ and stilbite, $\mathrm{Na}_{3} \mathrm{Ca}_{3} \mathrm{Al}_{8} \mathrm{Si}_{28} \mathrm{O}_{72} \cdot 30 \mathrm{H}_{2} \mathrm{O}$.

Keywords: vibrational spectroscopy; infrared; Raman; X-ray powder diffraction; identification; cyclosilicate; phyllosilicate; tectosilicate; minerals

\section{МИНЕРАЛИ ОД МАКЕДОНИЈА. ХХХ. КОМПЛЕМЕНТАРНО КОРИСТЕЊЕ НА ВИБРАЦИОНАТА СПЕКТРОСКОПИЈА И НА РЕНДГЕНСКАТА ДИФРАКЦИЈА ОД ПРАШОК ПРИ СПЕКТАР-СТРУКТУРНИ ИСТРАЖУВАЊА НА НЕКОИ ЦИКЛО-, ФИЛО- И ТЕКТОСИЛИКАТНИ МИНЕРАЛИ. ПРЕГЛЕДНА СТУДИЈА}

Даден е преглед на резултатите од комплементарното користење на вибрационата спектроскопија (инфрацрвена и раманска) и на рендгенската дифракција од прашок при идентификација и спектар-структурни корелации на некои цикло-, фило- и тектосиликатни минерали по потекло од Република Македонија. Изучувани се следните минерали: шерл, $\mathrm{Na}\left(\mathrm{Fe}^{2+}, \mathrm{Mg}_{3} \mathrm{Al}_{6}\left(\mathrm{BO}_{3}\right)_{3} \mathrm{Si}_{6} \mathrm{O}_{18}(\mathrm{OH})_{4}\right.$; берил, $\left(\mathrm{Be}, \mathrm{Mg}_{3} \mathrm{Al}_{2} \mathrm{Si}_{6} \mathrm{O}_{18}\right.$; хризотил, $\mathrm{Mg}_{3} \mathrm{Si}_{2} \mathrm{O}_{5}(\mathrm{OH})_{4}$; антигорит, $\left(\mathrm{Mg}, \mathrm{Fe}^{2+}\right)_{3} \mathrm{Si}_{2} \mathrm{O}_{5}(\mathrm{OH})_{4} ;$ талк, $\left(\mathrm{Mg}, \mathrm{Fe}^{2+}\right)_{3} \mathrm{Si}_{4} \mathrm{O}_{10}(\mathrm{OH})_{2} ; \quad$ клинохлор, $\left(\mathrm{Mg}, \mathrm{Fe}^{2+}\right)_{5} \mathrm{Si}_{3}\left(\mathrm{Al}, \mathrm{Cr}_{2} \mathrm{O}_{10}(\mathrm{OH})_{8} ;\right.$ цимрит, $\mathrm{BaAl}_{2} \mathrm{Si}_{2} \mathrm{O}_{8} \cdot \mathrm{H}_{2} \mathrm{O} ; \quad$ монтморилонит, $(\mathrm{K}, \mathrm{Ca})_{0.3}(\mathrm{Al}, \mathrm{Mg})_{2} \mathrm{Si}_{4} \mathrm{O}_{10}(\mathrm{OH})_{2} \cdot \mathrm{nH}_{2} \mathrm{O} ; \quad$ мусковит, $\mathrm{KAl}_{2}\left(\mathrm{Si}_{3} \mathrm{Al}\right) \mathrm{O}_{10}(\mathrm{OH}, \mathrm{F})_{2}$; флогопит, $\mathrm{KMg}_{3}\left(\mathrm{Si}_{3} \mathrm{Al}\right) \mathrm{O}_{10}(\mathrm{OH}, \mathrm{F})_{2} ;$ биотит, $\mathrm{K}\left(\mathrm{Mg}, \mathrm{Fe}^{2+}\right)_{3} \mathrm{AlSi}_{3} \mathrm{O}_{10}(\mathrm{OH}, \mathrm{F})_{2}$; шериданит, $(\mathrm{Mg}, \mathrm{Al})_{6}(\mathrm{Si}, \mathrm{Al})_{4} \mathrm{O}_{10}(\mathrm{OH})_{8} ; \quad$ албит, $\mathrm{NaAlSi}_{3} \mathrm{O}_{8} ; \quad$ микроклин, $\mathrm{KAlSi}_{3} \mathrm{O}_{8} ; \quad$ санидин, $(\mathrm{K}, \mathrm{Na})(\mathrm{Si}, \mathrm{Al})_{4} \mathrm{O}_{8}$ и стилбит, $\mathrm{Na}_{3} \mathrm{Ca}_{3} \mathrm{Al}_{8} \mathrm{Si}_{28} \mathrm{O}_{72} \cdot 30 \mathrm{H}_{2} \mathrm{O}$.

Клучни зборови: вибрациона спектроскопија; инфрацрвена; раманска; рендгенска дифракција од прашок; идентификација; циклосиликати; филосиликати; тектосиликати; минерали 


\section{INTRODUCTION}

Various types of native elements as well as oxide, hydroxide, sulfide, carbonate, sulfate, phosphate and silicate minerals are present in the vast ore deposits distributed all around the Republic of Macedonia, the silicate minerals being a considerable part of the complete mineral wealth of the country.

A plethora of instrumental techniques for mineral identification have been introduced during the last few decades, the most frequently used being X-ray diffraction [1, 2], infrared [3, 4] and Raman [5, 6] spectroscopy, optical diffuse reflectance [7] and thermal analysis [8,9] as well as the microscopy-based techniques (SEM-EDS [10, 11], TEM [12, 13], EMPA [14, 15]) which are extremely important in identifying amorphous and poorly crystalline mineral phases.

A systematic process of investigation of the minerals originating from the Republic of Macedonia in the course of the last 25 years has been undertaken [e. g. 16-20] (only a selection of our few review articles and one monograph is given). Minerals are mainly studied by Fourier transform infrared (FT IR) and micro-Raman spectroscopy as well as by X-ray powder diffraction (XRPD) [2124]. One of the reviews cited above [19] is related to the complementary use of vibrational spectroscopy (infrared and Raman) and XRPD in the process of detection and identification of some neso-, soro- and inosilicate minerals collected from various localities of R. Macedonia. In addition to this review [19], more details related to the classification of silicates, their deposits and occurrence as well as to the geological characteristics of R. Macedonia are presented in Refs. [16] and [20].

In this review, the results obtained by complementary use of vibrational spectroscopy (FT IR and Raman) and XRPD in the process of detection, identification and spectral and structural characterization of cyclo-, phyllo- and tectosilicate minerals collected from different localities in the Republic of Macedonia are summarized. The mineral identification is based on the comparison of our results with the corresponding literature data for the analogous mineral species originating from other world localities. The data comparison is not always straightforward, being accompanied by various difficulties among which the most important are related to: the quality of the instruments used and their resolution; the particle size and shape depending on the sample preparation conditions as well as the temperature at which the experiment was performed; the studied $2 \theta$ region of the collected Xray powder patterns as well as the studied vibrational spectral region; the purity of the specimen used in the experiment related to the locality where the specimen was collected from; the specimen quantity used in the experiment, etc.

\section{EXPERIMENTAL}

The distribution of the localities in the Republic of Macedonia from where the mineral samples were collected is given in Fig. 1. Crystals of the collected minerals were carefully picked up under an optical microscope and the sample was powdered prior to measurements.

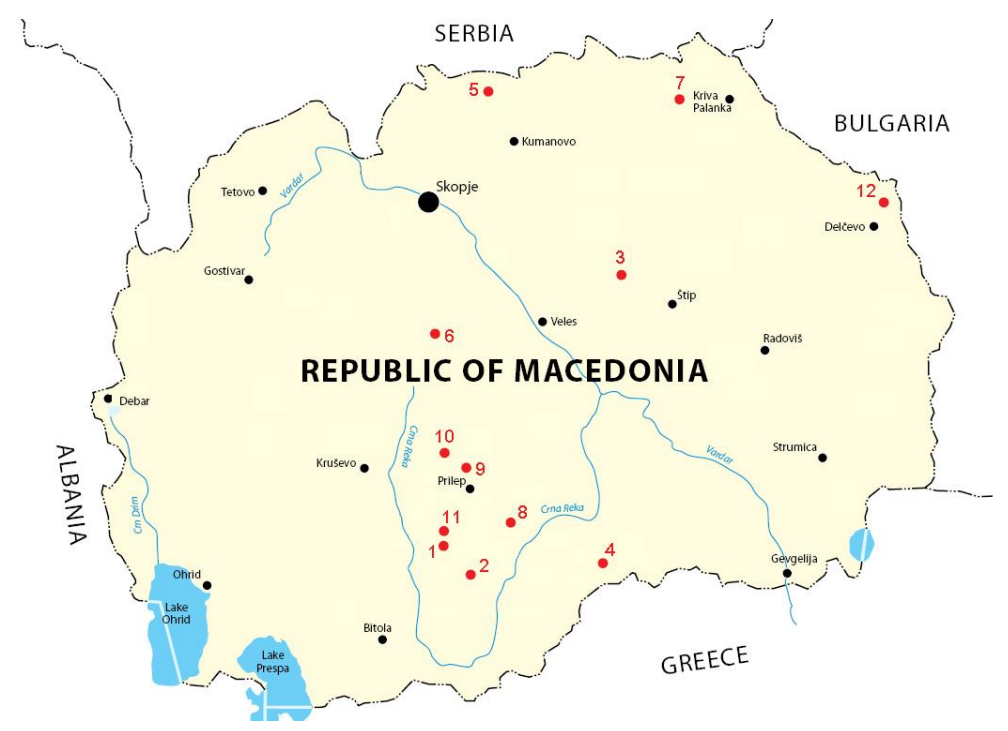

Fig. 1. Distribution of the localities in the Republic of Macedonia from where the studied silicate minerals were collected: 1) Bonče (schorl); 2) Čanište (beryl, biotite, microcline); 3) Bogoslovec (chrysotile); 4) Ržanovo (antigorite, talc); 5) Lojane (clinochlore); 6) Nežilovo (cymrite, muscovite); 7) Ginovci (montmorillonite); 8) Dunje (muscovite, stilbite); 9) Sivec (phlogopite, sheridanite); 10) Pelagon (biotite); 11) Alinci (albite); 12) Zvegor (sanidine) 
The FT IR spectra of the studied samples were recorded on a Perkin-Elmer FT IR system 2000 interferometer using the $\mathrm{KBr}$ pellet method.

The Raman spectra were recorded on three instruments: a micro-Raman multichannel spectrometer - Horiba Jobin Yvon Lab-Ram Infinity $(f \times 100)$ operating with a $532 \mathrm{~nm}$ laser line obtained from an Nd-YAG frequency-double laser; a Bruker FT Raman model 106/S connected to an Equinox 55 FT IR interferometer with a $1064 \mathrm{~nm}$ line of Nd-YAG frequency laser; and a Renishaw micro-Raman 1000 spectrometer equipped with a Peltier cooled CCD camera and Leica microscope $(f \times 50)$, the Raman effect being excited using the $514 \mathrm{~nm}$ line of an aircooled $\mathrm{Ar}^{+}$laser by Melles Griot. The measurements were carried at room temperature (RT) and the GRAMS/32 software [25] package was applied for the manipulations of the vibrational spectra.

A Philips Analytical PW 3710 X-ray diffractometer was used for XRPD (step $0.01^{\circ}$, time per step $2.5 \mathrm{~s}$ ). A generator with $50 \mathrm{kV}$ and current 30 $\mathrm{mA}$ was employed as a source for $\mathrm{Cu} K \alpha$ radiation. The unit cell parameters were calculated from their XRPD patterns using CRYSFIRE software [26]. The obtained values were refined using CHECKCELL [27] (a modified version of CELREF for analyzing the solutions given by CRYSFIRE).

The chemical composition of the individual minerals was determined by a JEOL-JSM 35-CF scanning electron microscope with a Tracor Northern TN-2000 X-ray microanalyzer, through an energy-dispersive system. Analyzed single crystals of the minerals were previously covered with a carbon layer with a thickness of $30 \mathrm{~nm}$ in a JEOL JEE-4X vacuum evaporator. The accelerating voltage was set to $25 \mathrm{keV}$, the probe current was adjusted to $2 \cdot 10^{-9} \mathrm{~A}$ and the counting time was set to $6 \mathrm{~s}$. Usually, three separate grains were analyzed from each sample (conventional centre and periphery). The analyses were carried out in a point (1 $\mu \mathrm{m})$ to avoid mechanical microinclusions. The analytical scope of EDS was from $\mathrm{Na}$ to $\mathrm{U}$. All the elements up to $\mathrm{Na}$ were determined as a difference up to $100 \mathrm{wt} \%$. Standards were used as follows: albite for $\mathrm{Na}$; corundum for $\mathrm{Al}$; barite for $\mathrm{Ba}$; diopside for $\mathrm{Mg}, \mathrm{Si}$ and $\mathrm{Ca}$; biotite for $\mathrm{K}$; chalcopyrite for $\mathrm{S}, \mathrm{Fe}$ and $\mathrm{Cu}$; pure substances for $\mathrm{Mo}, \mathrm{Mn}, \mathrm{Ti}$, $\mathrm{Cd}, \mathrm{Ag}, \mathrm{Cr}$ and $\mathrm{Zr}$; stibnite for $\mathrm{Sb}$.

\section{RESULTS AND DISCUSSION}

The minerals' composition was determined by conducting chemical analysis of each studied mineral (Table 1). In addition to the chemical formula derived from the chemical analysis, the ideal chemical formula and empirical formula of the corresponding mineral are presented in Table 1.

\subsection{Cyclosilicates (ring silicates)}

Schorl (from the tourmaline group) and ber$\mathrm{yl}$ are the only two cyclosilicate minerals evidenced to exist in R. Macedonia. Although the Fourier analysis of tourmaline's structure was published more than 65 years ago [29], in the last two decades, there have been several vibrational spectroscopy [30-33] and XRD studies [34, 35] focused on elucidation of the structural varieties within the chemical composition of the tourmaline mineral group. According to Hawthorne and Hendry [36], the general chemical formula of the most common boron-bearing mineral is $\mathrm{XY}_{3} \mathrm{Z}_{6} \mathrm{~T}_{6} \mathrm{O}_{18}\left(\mathrm{BO}_{3}\right)_{3}(\mathrm{O}, \mathrm{OH})_{3}(\mathrm{OH}, \mathrm{F}, \mathrm{O})$ [usually, $\mathrm{X}=$ $\mathrm{Na}, \mathrm{K}, \mathrm{Ca}, \mathrm{Mg}$, (vacancy); $\mathrm{Y}=\mathrm{Li}, \mathrm{Mg}, \mathrm{Fe}^{2+, 3+}, \mathrm{Al}$, $\left.\mathrm{Ti} ; \mathrm{Z}=\mathrm{Mg}, \mathrm{Fe}^{3+}, \mathrm{Al}\right]$. Tourmaline has a rhombohedral structure ( $R 3 m$ symmetry; $Z=3$ ) where cornersharing tetrahedra, principally occupied by $\mathrm{Si}$ atoms (sometimes $\mathrm{Al}$ can replace $\mathrm{Si}$ atoms) form hexagonal $\mathrm{Si}_{6} \mathrm{O}_{18}$ rings [37, 38]. The presence of a large number of substitutional atoms and vacancies involves additional complexity in the tourmaline structure [39, 40] resulting in a great number of endmember minerals, such as schorl $\left[\mathrm{NaFe}_{3} \mathrm{Al}_{6}\left(\mathrm{BO}_{3}\right)_{3} \mathrm{Si}_{6} \mathrm{O}_{18}(\mathrm{OH})_{4}\right]$, dravite $\left[\mathrm{NaMg}_{3} \mathrm{Al}_{6}\left(\mathrm{BO}_{3}\right)_{3} \mathrm{Si}_{6} \mathrm{O}_{18}(\mathrm{OH})_{4}\right]$, elbaite $\left[\mathrm{Na}\left(\mathrm{Li}, \mathrm{Al}_{3}\right)_{3} \mathrm{Al}_{6}\left(\mathrm{BO}_{3}\right)_{3} \mathrm{Si}_{6} \mathrm{O}_{18}(\mathrm{OH})_{4}\right]$ (whose red variety is known as rubellite), buergerite $\left[\mathrm{NaFe}^{3+}{ }_{3} \mathrm{Al}_{6}\left(\mathrm{BO}_{3}\right)_{3} \mathrm{Si}_{6} \mathrm{O}_{18}(\mathrm{O}, \mathrm{F})_{4}\right]$, uvite $\quad[(\mathrm{Ca}, \mathrm{Na})$ $\left.(\mathrm{Mg}, \mathrm{Fe})_{3} \mathrm{Al}_{5} \mathrm{Mg}\left(\mathrm{BO}_{3}\right)_{3} \mathrm{Si}_{6} \mathrm{O}_{18}(\mathrm{OH}, \mathrm{F})_{4}\right]$, hydroxyuvite, liddicoatite, olenite, chromdravite, vanadiumdravite, foitite, magnesiofoitite, feruvite, povondraite and rossmanite (the ideal chemical formulae of the most common ones are given). In the meantime, numerous papers related to the crystal structure study of various types of tourmaline have been published in the literature [41-47].

The present study pays attention to the possibility of undoubtedly identifying the only tourmaline (as the schorl variety) found in Macedonia according to the results obtained from the IR, micro-Raman and XRPD studies and X-ray microprobe analysis. In addition, although a systematized view on the vibrational spectra of natural tourmaline endmembers and their solid solution series was published in the literature [30-33, 48-50], it should be mentioned that, to the best of our knowledge, the Raman spectrum of the schorl type was not discussed until 2009. Here, an attempt to assign the bands in the Raman spectrum of schorl in line with the previously published Raman spectra of the tourmaline endmember series is presented. Recently, the Raman spectrum of schorl was discussed in detail [51]. 


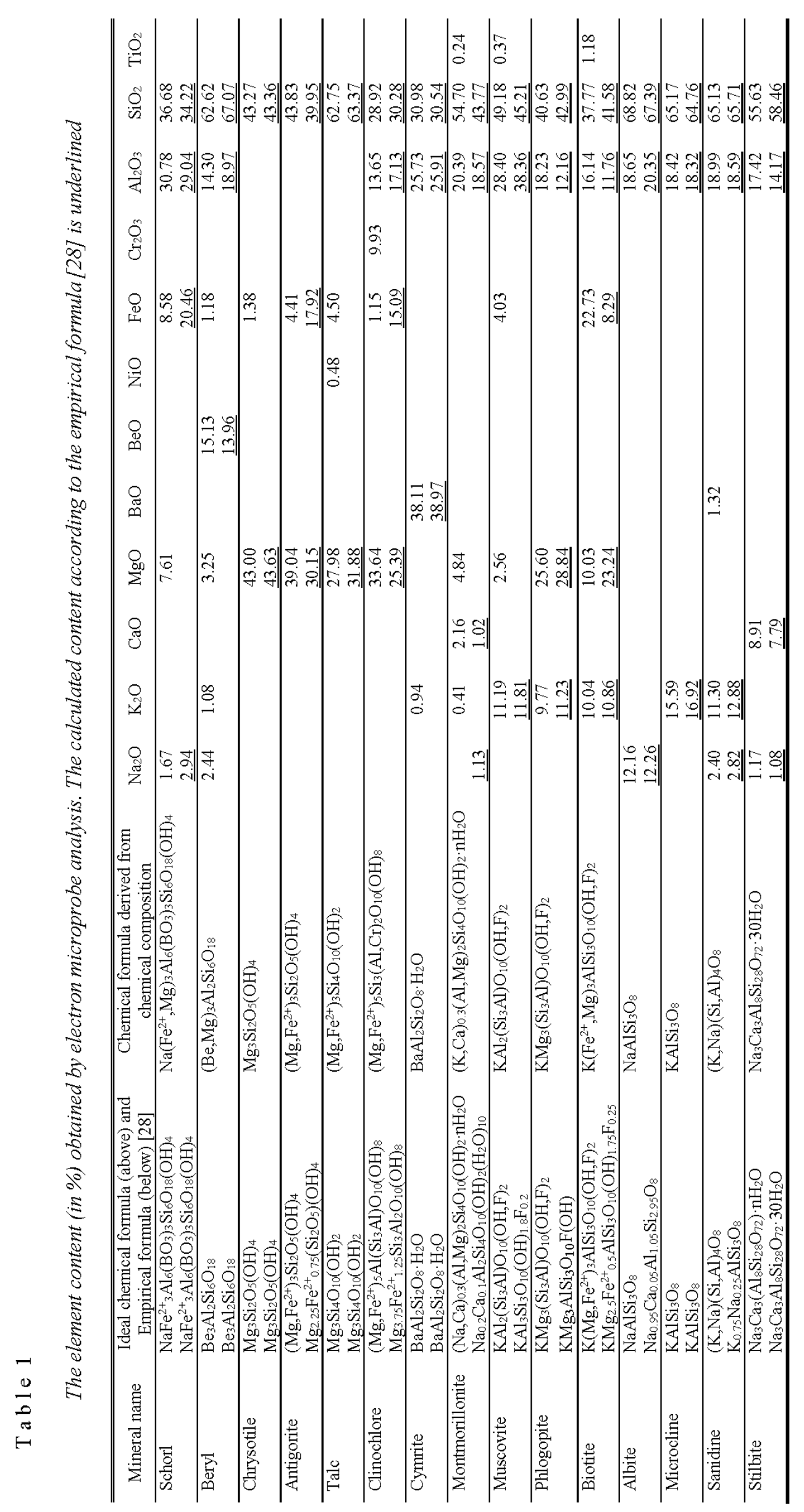


The structure of beryl $\left(\mathrm{Be}_{3} \mathrm{Al}_{2} \mathrm{Si}_{6} \mathrm{O}_{18}\right)$ consists of six-sided rings of $\mathrm{Si}_{6} \mathrm{O}_{18}{ }^{12-}$ that are bonded with $\mathrm{Be}^{2+}$ cations (in tetrahedral) and $\mathrm{Al}^{3+}$ cations (in octahedral coordination) forming channels along the $c$-axis $[52,53]$. These channels are approximately 2.8 to $5.1 \AA$ wide, allowing incorporation of numerous trace elements (mostly alkali and earth-alkali cations) as well as water and $\mathrm{CO}_{2}$ molecules [52-55]. This particular interest provided the vibrational studies explaining the existence of two structurally different types of $\mathrm{H}_{2} \mathrm{O}$ molecule (types I and II) in the channel $[54,55]$. The structural difference, expressed in regard to the orientation of the $C_{2}$ symmetry axis of the water molecule, was later demonstrated by the existence of another $\mathrm{H}_{2} \mathrm{O}$ form (type III) associated with the heavy alkali atoms [56]. Therefore, despite the numerous assignments of the IR [48, 57-60] and Raman bands [48, 57, 59-64] arising from the $\mathrm{Si}_{6} \mathrm{O}_{18}{ }^{12-}$ vibrations, it would be important to provide evidence whether vibrational spectroscopy could additionally unravel the number of different $\mathrm{H}_{2} \mathrm{O}$ molecules in the studied beryl specimen since this is the first evidence of its existence in the territory of R. Macedonia.

Details of the complementary use of vibrational spectroscopy and XRPD for identification of schorl (tourmaline) and beryl cyclosilicates from R. Macedonia are presented in Ref. [65]. Here, these results are summarized and presented together with the corresponding findings related to the study of phyllo- and tectosilicate minerals from R. Macedonia.

\subsubsection{Vibrational spectra}

Tourmaline (schorl), $\mathrm{Na}\left(\mathrm{Fe}^{2+}, \mathrm{Mg}\right)_{3} \mathrm{Al}_{6}\left(\mathrm{BO}_{3}\right)_{3} \mathrm{Si}_{6} \mathrm{O}_{18}(\mathrm{OH})_{4}$

The IR spectra recorded at RT and liquid nitrogen temperature (LNT) for the studied schorl (tourmaline) are presented in Fig. 2, whereas the band assignments in the stretching $\mathrm{OH}$ region as well as in the $\mathrm{Si}_{6} \mathrm{O}_{18}$ region of various types of tourmaline are given in Table 1 and Table 2 of Ref. [65].

According to the factor group analysis, elbaite, Fe-elbaite, dravite and schorl endmembers should show three $\mathrm{OH}$ stretching bands whereas the Li-bearing schorl shows four $\mathrm{OH}$ stretchings (related to the large differences in electronegativity as well as the difference in the ionic radii of the $\mathrm{Li}$ and $\mathrm{Fe}$ promoting the formation of a solid solution in which $\mathrm{Fe}^{2+}$ and $\mathrm{Li}^{+}$cations are not randomly distributed) [31]. However, Gonzales-Carreno et al. [38] observed four $\mathrm{OH}$ stretchings in Fe-elbaite, whereas Grice and Ercit registered only two bands in the elbaite mineral type (Table 1 in Ref. [65]). Since the fourth band arising from such a chemical composition (found at $3594 \mathrm{~cm}^{-1}$ by Castaneda et al. [31]) was not registered in our spectrum, whereas the observed wavenumbers of the stretching $\mathrm{OH} 3$ bands below $3600 \mathrm{~cm}^{-1}$ (3562 and 3492 $\mathrm{cm}^{-1}$ ) are in agreement with the corresponding ones found for the schorl species (Table 1 in Ref. [65]) it can be preliminarily presumed that the sample belongs to this mineral type.
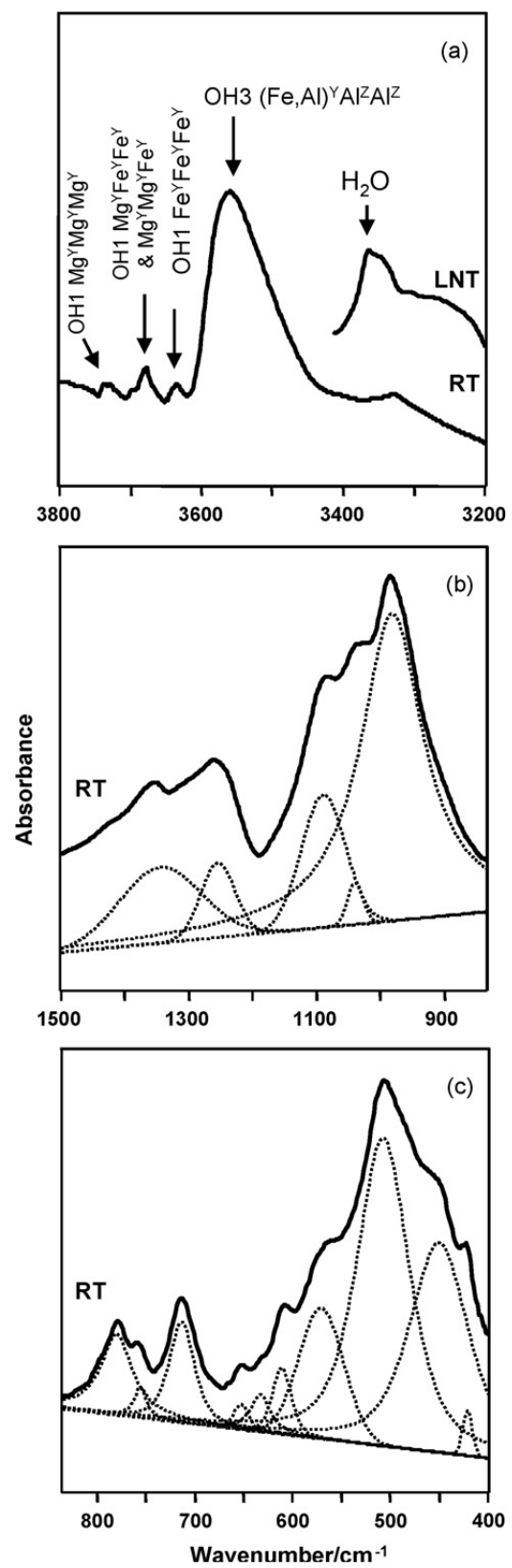

Fig. 2. IR spectrum of schorl in the stretching $\mathrm{OH}$ and $\mathrm{H}_{2} \mathrm{O}$ region (a) and in the $\mathrm{Si}_{6} \mathrm{O}_{18}$ region (b and c). The result of the curve fitting is presented by dotted lines (b and c). RT: room temperature spectrum; LNT: liquid nitrogen temperature spectrum. 
However, it should be pointed out that a slightly different IR spectral view in the 3800$3600 \mathrm{~cm}^{-1}$ region was observed in the corresponding literature data published by Castaneda et al. [31] and Gonzales-Carreno et al. [38]. Namely, the first group of authors registered only one band (at $3628 \mathrm{~cm}^{-1}$ ), whereas two bands (at 3738 and 3633 $\mathrm{cm}^{-1}$ ) were reported by Gonzales-Carreno et al. [38] (Table 1 in Ref. [65]). The higher-frequency band was attributed to the stretching vibration of the $\mathrm{OH} 1$ group coordinated by three $\mathrm{Mg}$ atoms in $\mathrm{Y}$ sites $\left(\mathrm{Mg}^{\mathrm{Y}} \mathrm{Mg}^{\mathrm{Y}} \mathrm{Mg}^{\mathrm{Y}}\right.$ combination) whereas the lower-frequency one was prescribed to the $\mathrm{OH} 1$ stretching involving $\mathrm{Fe}^{\mathrm{Y}} \mathrm{Fe}^{\mathrm{Y}} \mathrm{Fe}^{\mathrm{Y}}$ coordination. Similarly, the band observed by Gonzales-Carreno et al. [38] at $3628 \mathrm{~cm}^{-1}$ was assigned as $\mathrm{OH} 1$ stretching involving $\mathrm{Fe}^{\mathrm{Y}} \mathrm{Fe}^{\mathrm{Y}} \mathrm{R}^{\mathrm{Y}}$ coordination. Two bands with practically the same frequency (3735 and $3635 \mathrm{~cm}^{-1}$ ) were observed in our spectrum, by analogy with the literature data prescribed to $\mathrm{OH} 1$ stretching involving $\mathrm{Mg}^{\mathrm{Y}} \mathrm{Mg}^{\mathrm{Y}} \mathrm{Mg}^{\mathrm{Y}}$ and $\mathrm{Fe}^{\mathrm{Y}} \mathrm{Fe}^{\mathrm{Y}} \mathrm{Fe}^{\mathrm{Y}}$ coordination, respectively. Their similar intensity implies that both cation combinations are equally probable assuming that the content of $\mathrm{Mg}$ and $\mathrm{Fe}$ should be nearly the same. This indirect conclusion derived by IR spectroscopy was confirmed by Xray microprobe analysis (Table 1) [65].

Here, it is very important to point out that the additional band at $3679 \mathrm{~cm}^{-1}$ (not found in the literature, Table 1 in Ref. [65]) could be prescribed to the vibration where half of $\mathrm{Y}$ sites are occupied by $\mathrm{Mg}$ and the other half by $\mathrm{Fe}$ atoms coordinating the $\mathrm{OH} 1$ group $\left(\mathrm{Mg}^{\mathrm{Y}} \mathrm{Fe}^{\mathrm{Y}} \mathrm{Fe}^{\mathrm{Y}}\right.$ and $\mathrm{Mg}^{\mathrm{Y}} \mathrm{Mg}^{\mathrm{Y}} \mathrm{Fe}^{\mathrm{Y}}$ combinations). Since the probability of such a structural arrangement around the $\mathrm{OH} 1$ group is twice as high as the "single" probability of either $\mathrm{Fe}^{\mathrm{Y}} \mathrm{Fe}^{\mathrm{Y}} \mathrm{Fe}^{\mathrm{Y}}$ or $\mathrm{Mg}^{\mathrm{Y}} \mathrm{Mg}^{\mathrm{Y}} \mathrm{Mg}^{\mathrm{Y}}$ combinations, it has doubled intensity (Fig. 2a). Contrary to the literature data (Table 1 in Ref. [65]), no bands due to $\mathrm{H}_{2} \mathrm{O}$ stretching were observed in the RT IR spectrum, whereas the corresponding band appeared in the LNT IR spectrum (Fig. 2a) at $3370 \mathrm{~cm}^{-1}$.

Two well-resolved bands at 3675 and 3661 $\mathrm{cm}^{-1}$ and one weak band at $3646 \mathrm{~cm}^{-1}$ (Fig. 3a) were observed in the $\mathrm{OH}$ stretching Raman region. By correlation of the Raman results with the corresponding data obtained by IR measurements (Fig. 2a) (see also Table 1 in Ref. [65]), an assumption could be drawn that the Raman peaks at 3675 and $3646 \mathrm{~cm}^{-1}$ involve $\mathrm{OH} 1 \mathrm{Mg}^{\mathrm{Y}} \mathrm{Mg}^{\mathrm{Y}} \mathrm{Fe}^{\mathrm{Y}}$ and $\mathrm{OH} 1$ $\mathrm{Fe}^{\mathrm{Y}} \mathrm{Fe}^{\mathrm{Y}} \mathrm{Fe}^{\mathrm{Y}}$ cation combinations, respectively, whereas the band at $3661 \mathrm{~cm}^{-1}$ might comprise the combination of two $\mathrm{Mg}$ atoms and one $\mathrm{Fe}$ atom in the $\mathrm{Y}$ structural sites $\left(\mathrm{OH} 1 \mathrm{Mg}^{\mathrm{Y}} \mathrm{Fe}^{\mathrm{Y}} \mathrm{Fe}^{\mathrm{Y}}\right)$. The $\mathrm{OH}$ deformations give rise to a wide and complex band at $1600 \mathrm{~cm}^{-1}$ (Fig. 3a).
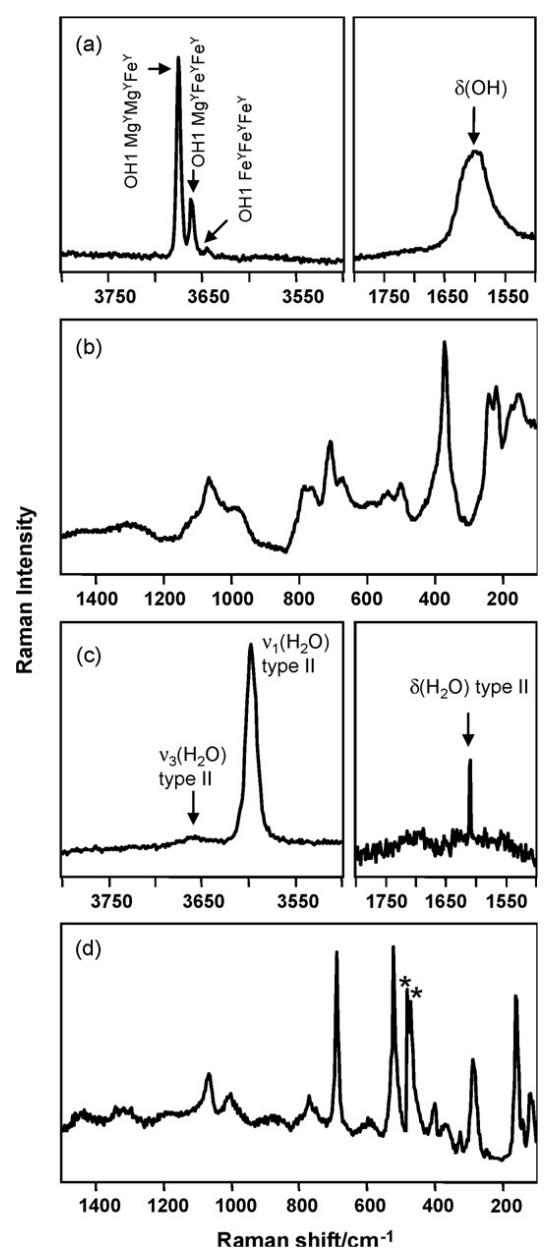

Fig. 3. Raman spectra of schorl and beryl in the $\mathrm{OH}$ and $\mathrm{H}_{2} \mathrm{O}$ regions (a and c, respectively) and in the $\mathrm{Si}_{6} \mathrm{O}_{18}$ region (b and $\mathrm{d}$, respectively). The bands marked with an asterisk arise from microcline impurity.

The IR spectrum of schorl in the region 1500 $400 \mathrm{~cm}^{-1}$ is presented in Figures $2 \mathrm{~b}$ and c. The assignment of the bands is given in Table 2 of Ref. [65], together with the IR spectra of various tourmalines studied by other authors (see citations $32-35$ in Ref. [65]). The higher-frequency region 1500-800 $\mathrm{cm}^{-1}$ (Fig. 2b) could not provide satisfactory discrimination between various tourmaline types (Table 2 in Ref. [65]) since the bands that appeared in this region were not sensitive to compositional changes. Both highest-frequency peaks (1353 and $1255 \mathrm{~cm}^{-1}$ ) are attributed to antisymmetric $\mathrm{BO}_{3}$ stretching, while the remaining bands at 1085, 1039 and $985 \mathrm{~cm}^{-1}$ are prescribed to $\mathrm{Si}-\mathrm{O}$ and $\mathrm{Si}-\mathrm{O}-\mathrm{Al}$ stretching. The proposed assignment is in line with the literature data (Table 2 in Ref. [65]). The exception is the peak around $1100 \mathrm{~cm}^{-1}$ attributed (without providing any explanation) to $\delta(\mathrm{MgOH})$ (citation 34 in Ref. [65]). However, the assignment as $v(\mathrm{Si}-\mathrm{O})$ mode of the band at $1140 \mathrm{~cm}^{-1}$ in a structurally similar $12-$ member ring mineral which does not contain $\mathrm{OH}$ 
groups (milarite $-\mathrm{K}_{2} \mathrm{Ca}_{4} \mathrm{Al}_{2} \mathrm{Be}_{4} \mathrm{Si}_{24} \mathrm{O}_{60} \cdot \mathrm{H}_{2} \mathrm{O}$ ) [48] as well as the study of the IR spectra of different phyllosilicate minerals containing $\mathrm{OH}$ groups [66] approves the $\mathrm{Si}-\mathrm{O}$ stretching character of the discussed band around $1100 \mathrm{~cm}^{-1}$.

The IR spectral view below $800 \mathrm{~cm}^{-1}$ (Fig. 2c) could, to some extent, satisfactorily discriminate between various types of tourmaline (Table 2 in Ref. [65]). Namely, it can be seen that some of the bands observed at 631 and $449 \mathrm{~cm}^{-1}$ (curve-fitted spectrum, Fig. 2c) appear as solely characteristic for the schorl variety (Table 2 in Ref. [65]), whereas the observed strongest band at $510 \mathrm{~cm}^{-1}$ was found only in the dravite spectrum shifted to $520 \mathrm{~cm}^{-1}$. On the other hand, the registered peak at $758 \mathrm{~cm}^{-1}$ assigned as $v\left(\mathrm{R}^{\mathrm{IV}}-\mathrm{O}\right)$ mode $[\mathrm{R}=\mathrm{Al}, \mathrm{Mg}, \mathrm{Fe}]$ was shifted to lower wavenumbers in the case of dravite ( 727 $\left.\mathrm{cm}^{-1}\right)$ and elbaite $\left(735 \mathrm{~cm}^{-1}\right)$ due to the difference in electronegativity between the $\mathrm{Fe}, \mathrm{Mg}$ and $\mathrm{Al}$ cations and the difference in $\mathrm{R}-\mathrm{O}$ force constants.

Although the factor group analysis for tourmaline predicts $28 A_{1}$ and $49 E$ active modes in the Raman spectra [49], there is no possibility of detecting all of them experimentally [33]. As a result of different optical parameters of the endmember tourmaline species, there are some differences between their Raman spectra (Table 3 in Ref. [65]). The corresponding Raman spectrum of the schorl sample is presented in Fig. 3b. The main characteristics are the strongest peaks observed at 1066, 369 and $239 \mathrm{~cm}^{-1}$ arising from $\mathrm{Si}-\mathrm{O}$ stretching, $\mathrm{Al}-\mathrm{O}$ stretching and $\mathrm{O}-$ $\mathrm{Al}-\mathrm{O}$ bending vibrations (Table 3 in Ref. [65]). They could, to some extent, differentiate between schorl and the other tourmaline endmembers. Additionally, the Raman spectrum of the schorl type was characterized by the doublet at 770 and $784 \mathrm{~cm}^{-1}$, whereas a singlet appeared in other tourmaline mineral types (Table 3 in Ref. [65]).

\section{Beryl, $(\mathrm{Be}, \mathrm{Mg})_{3} \mathrm{Al}_{2} \mathrm{Si}_{6} \mathrm{O}_{18}$}

Beryl is a nominally anhydrous mineral, but in spite of that, the RT IR spectra in the region of $\mathrm{H}_{2} \mathrm{O}$ (and $\mathrm{OH}$ ) stretching vibrations (Fig. 4a) demonstrated the existence of two well-resolved bands centered at $3592 \mathrm{~cm}^{-1}$ (B-notation) and 3660 $\mathrm{cm}^{-1}$ (C-notation) whereas in the corresponding LNT IR spectrum (Fig. 4a) an additional very weak band at $3697 \mathrm{~cm}^{-1}$ (A-notation) was defined. Such a spectral view is a strong indication about the dominant presence of one type of $\mathrm{H}_{2} \mathrm{O}$ molecule in the existing channels along the $c$-axis in the beryl structure $[56,59]$. Namely, type $\mathrm{I}_{2} \mathrm{O}$ molecules (arranged so that the symmetry axis of the molecule is perpendicular to the channel axis and typical for alkali-free beryls), represented by the bands in the 3690-3699 $\mathrm{cm}^{-1}$ and $3629-3650 \mathrm{~cm}^{-1}$ regions (Table 4 in Ref. [65]), were practically absent in our RT spectrum (except the very weak peak at $3697 \mathrm{~cm}^{-1}$ in the LNT spectrum). On the other hand, the bands from stretching of type II $\mathrm{H}_{2} \mathrm{O}$ molecules (connected with alkali-bearing beryls) appeared in the $3660-3674 \mathrm{~cm}^{-1}$ and 3590 $3596 \mathrm{~cm}^{-1}$ regions (Table 4 in Ref. [65]) being typical characteristics for the studied beryl specimen. Furthermore, the $\mathrm{H}_{2} \mathrm{O}$ bending vibration $\left(1623 \mathrm{~cm}^{-1}\right.$, Fig. 4 b) could serve as additional evidence for the presence of type $\mathrm{II}_{2} \mathrm{O}$ molecules since its wavenumber was about $20 \mathrm{~cm}^{-1}$ higher than the corresponding band of type $\mathrm{I}_{2} \mathrm{O}$ molecules (absent in the studied IR spectrum, Table 4 in Ref. [65]). The studied beryl neither contained a third $\mathrm{H}_{2} \mathrm{O}$ type that has the same direction of $C_{2}$ symmetry axis as type I water [56] nor $\mathrm{CO}_{2}$ molecules because the bands due to their IR active modes were not registered (Table 4 in Ref. [65]).

According to the chemical analysis obtained, the mineral belongs to the high alkali-bearing beryl type with a high content of sodium and potassium $\left[\omega\left(\mathrm{Na}_{2} \mathrm{O}\right)=2.44 \%, \omega\left(\mathrm{K}_{2} \mathrm{O}\right)=1.08 \%\right]$ (Table 1). In addition, the results from the chemical analysis were spectroscopically confirmed by the view of the diagnostic bands (A, B, and C) (Fig. 4a) whose intensity is arranged in the following sequence: $\mathrm{B}$ $>\mathrm{C} \gg \mathrm{A}$, significantly different from the results obtained by Lodzinski et al. [60] for low alkali (order $\mathrm{A}>\mathrm{B}>\mathrm{C}$ ) and medium alkali-bearing beryl samples $(\mathrm{B}>\mathrm{A}>\mathrm{C})$.

The view of the Raman spectrum of beryl in the $\mathrm{H}_{2} \mathrm{O}$ stretching region (Fig. $3 \mathrm{c}$ ) conforms to the expectations derived from the IR results. Namely, the strong band at $3596 \mathrm{~cm}^{-1}$ undoubtedly arises from the $v_{1}$ mode of type II water molecules whereas the very weak band at $3663 \mathrm{~cm}^{-1}$ is attributed to the corresponding $v_{3}$ type vibration. The band from $\mathrm{H}_{2} \mathrm{O}$ bending is weak and appeared at $1610 \mathrm{~cm}^{-1}$ (Fig. 3c). No bands from type I water molecules were registered in the stretching and bending regions, implicit confirmation for their absence in the structure of the studied beryl.

The beryl IR spectrum below $1500 \mathrm{~cm}^{-1}$ was characterized by three well-defined regions (Fig. 4b and c). The strongest bands that appeared at higher wavenumbers $\left(1200-850 \mathrm{~cm}^{-1}\right)$ are attributed to $\mathrm{Si}-\mathrm{O}$ stretching (Table 4 in Ref. [65]) except the shoulder at $1140 \mathrm{~cm}^{-1}$ (Fig. $4 \mathrm{~b}$ ) resulting from the longitudinal (LO) $A_{2 u}$ mode since it also appears as a shoulder in the single-crystal absorption spectrum of beryl at very close frequency $\left(1155 \mathrm{~cm}^{-1}\right)$ [58]. On the other hand, a subtle discrepancy in this region involves the weak band at $1085 \mathrm{~cm}^{-1}$ [60], absent in our and other 
IR beryl spectra [48, 58] (Table 4 in Ref. [65]). The very strong absorption observed at $1017 \mathrm{~cm}^{-1}$ was an unexpected spectroscopic outcome for beryl because the literature data $[58,60]$ point out the appearance of a weak band compared to the strongest peak found in the $950-970 \mathrm{~cm}^{-1}$ region. The increase of the 1017 $\mathrm{cm}^{-1}$ band intensity is explained by the presence of microcline impurity since the frequency of the most intense microcline IR peak [67] strongly coincided with the mentioned beryl band. Obviously, microcline, being very common in the Čanište locality, is associated with beryl crystals confirmed by chemical analysis as well (Table 1). The presence is even more indicative from the view of the beryl Raman spectrum (see forthcoming discussion).
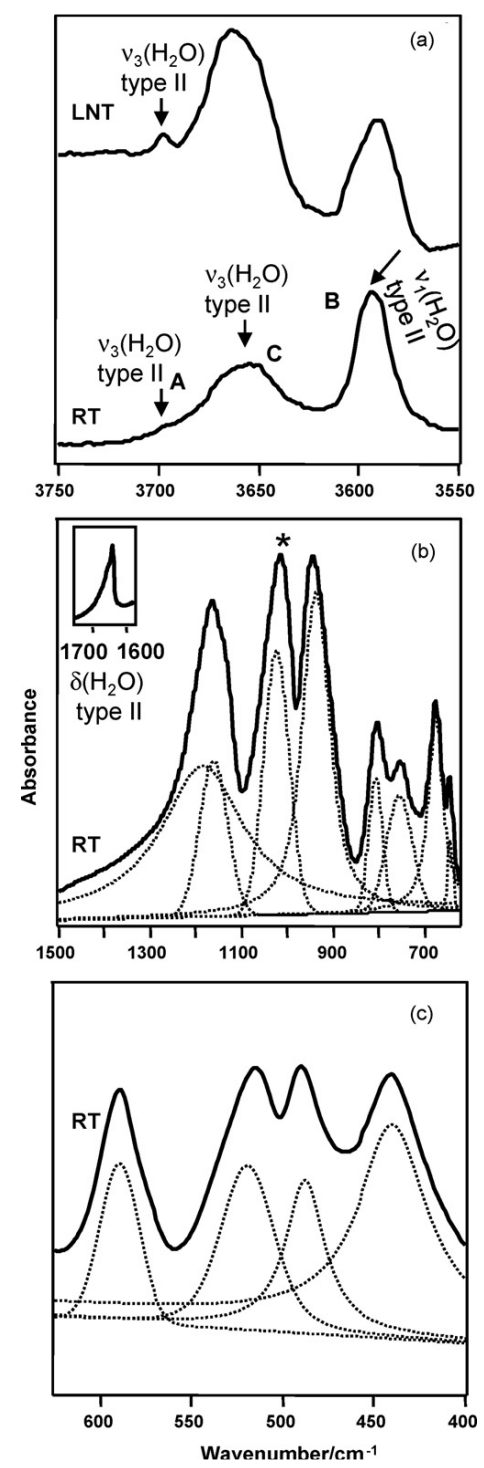

Fig. 4. IR spectrum of beryl in the stretching $\mathrm{H}_{2} \mathrm{O}$ region (a) and in the $\mathrm{Si}_{6} \mathrm{O}_{18}$ region (b and c). The result of the curve fitting is given below the spectra in (b) and (c). The band marked with an asterisk is mainly a result of the presence of microcline impurity. RT: room temperature spectrum; LNT: liquid-nitrogen temperature spectrum.
The bands ranging from 850 to $655 \mathrm{~cm}^{-1}$ are predominantly attributed to $\mathrm{Be}-\mathrm{O}$ stretching whereas the bands around 650 and $590 \mathrm{~cm}^{-1}$ are typical for beryl ring structure vibrations [60]. The lowestfrequency bands are due to $\mathrm{Al}-\mathrm{O}$ vibrations from $\mathrm{AlO}_{6}$ octahedra (488 and $\left.524 \mathrm{~cm}^{-1}\right)$ and from $\mathrm{O}-\mathrm{Si}-$ $\mathrm{O}$ deformations $\left(519 \mathrm{~cm}^{-1}\right)$ (Table 4 in Ref. [65]).

The Raman spectrum of beryl is presented in Figure 3d, whereas Table 4 in Ref. [65] reports the band assignments according to the group theory that predict Raman active modes: $7 A_{1 g}+13 E_{1 g}+16 E_{2 g}$ [33]. The Raman spectral behavior of beryl has been the subject of many studies (Table 4 in Ref. [65]) and is well established. Therefore, here, it should be pointed out that the existence of the bands at 473 and $480 \mathrm{~cm}^{-1}$ as well as the increase of the intensity of the bands at $516 \mathrm{~cm}^{-1}$ (not typical for beryl) is explained by the microcline impurity presence in the studied beryl sample (Fig. 4d and Table 4 in Ref. [65]) [68]. The majority of the other bands were found at frequencies very close to those reported in the literature (Table 4 in Ref. [65]).

\subsubsection{X-ray powder diffraction}

The XRPD patterns have also confirmed the studied minerals from Bonče and Čanište as schorl and beryl, respectively (Tables 2 and 3 ).

Table 2

The most intense maxima from the $X$-ray powder diagram of the studied schorl mineral used to calculate the unit cell parameters

\begin{tabular}{|c|c|c|c|c|c|}
\hline$h$ & $k$ & $l$ & $d_{\text {obs }}$ & $d_{\text {cal }}$ & $d_{\text {diff }}$ \\
\hline 0 & 1 & 2 & 6.395 & 6.3856 & 0.0094 \\
\hline 2 & 0 & 2 & 4.9887 & 4.9865 & 0.0022 \\
\hline 3 & 0 & 0 & 4.6114 & 4.6089 & 0.0025 \\
\hline 1 & 2 & 2 & 4.2317 & 4.2292 & 0.0025 \\
\hline 2 & 2 & 0 & 3.9944 & 3.9914 & 0.003 \\
\hline 1 & 0 & 4 & 3.4862 & 3.4835 & 0.0027 \\
\hline 2 & 1 & 4 & 2.9631 & 2.9645 & -0.0014 \\
\hline 5 & 0 & 2 & 2.5808 & 2.5815 & -0.0007 \\
\hline 3 & 2 & 4 & 2.3808 & 2.3799 & 0.0009 \\
\hline 1 & 5 & 2 & 2.3486 & 2.3476 & 0.001 \\
\hline 0 & 5 & 4 & 2.1944 & 2.1929 & 0.0015 \\
\hline 3 & 4 & 2 & 2.1665 & 2.1676 & -0.0011 \\
\hline \multicolumn{4}{|c|}{$\begin{array}{l}\text { Unit Cell Par. }{ }^{\text {obs }} \\
a=15.9535 \AA \\
c=14.3876 \AA \\
V=3171.25 \AA^{3}\end{array}$} & \multicolumn{2}{|c|}{$\begin{array}{l}\text { Unit Cell Par.[70] } \\
a=15.939 \AA \\
c=7.146 \AA \\
V=1570.4 \AA^{3} \\
Z=3 \\
\text { Trigonal }(R 3 m)\end{array}$} \\
\hline
\end{tabular}


Here, it should be mentioned that the calculated unit cell volume of the schorl mineral is nearly twice as large as that in the literature [69] (the same stands for $l$ values within the Miller indices) due to the twice as long calculated $c$-axis in its unit cell (Table 2).

\section{T a b le 3}

The most intense maxima from the $X$-ray powder diagram of the studied beryl mineral used to calculate the unit cell parameters

\begin{tabular}{|c|c|c|c|c|c|}
\hline$h$ & $k$ & $l$ & $d_{\text {obs }}$ & $d_{\text {cal }}$ & $d_{\text {diff }}$ \\
\hline 0 & 1 & 0 & 8.0332 & 7.989 & 0.0442 \\
\hline 0 & 0 & 2 & 4.6047 & 4.6039 & 0.0008 \\
\hline 0 & 2 & 0 & 3.9942 & 3.9945 & -0.0003 \\
\hline 1 & 1 & 2 & 3.2584 & 3.2585 & -0.0001 \\
\hline 0 & 0 & 4 & 2.3017 & 2.3019 & -0.0002 \\
\hline 0 & 1 & 4 & 2.2121 & 2.212 & 0.0001 \\
\hline \multicolumn{4}{|c|}{$\begin{array}{l}\text { Unit Cell Par. }{ }^{\text {obs }} \\
a=9.2179 \AA \\
c=9.2997 \AA \\
V=677.038 \AA^{3}\end{array}$} & \multicolumn{2}{|c|}{$\begin{array}{l}\text { Unit Cell Par.[71] } \\
a=9.22 \AA \\
c=9.196 \AA \\
V=677.03 \AA^{3} \\
Z=2 \\
\text { Hexagonal } \\
(P 6 / m m c)\end{array}$} \\
\hline
\end{tabular}

\subsection{Phyllosilicates (sheet silicates)}

Phyllosilicates (sheet silicates) are abundant and important minerals particularly in geological environments roughly $20 \mathrm{~km}$ below the Earth's surface. They are commonly found in intermediate and felsic igneous rocks, abundant in many metamorphic and sedimentary rocks and sediments [72]. Spectroscopic methods have become a vital investigative tool in determinative mineralogy [22, 23, 73-76]. Several studies have been undertaken to obtain the IR spectra of chrysotile [77-80], antigorite $[78,79,81,82]$, talc $[78,83-86]$, clinochlore [85, 87, 88], cymrite [89] and montmorillonite $[81,90]$. The Raman spectra of chrysotile [91, 92], antigorite [91], talc [93], clinochlore [87, 88, 94], cymrite [89] and montmorillonite [95] were used for the mineral characterization as well. Several studies have been undertaken so far to describe the vibrational spectra of muscovite $[78,81,96-$ 103] and phlogopite [81, 86, 90, 97, 98, 101, 103106]. On the other hand, the IR spectrum of biotite is only presented in the Mineral Atlas [97] and on the internet [98] whereas its Raman spectrum is found in internet databases [107, 108]. In addition, to the best of our knowledge, neither infrared nor Raman data have been found in the literature for the sheridanite mineral.
Details of the use of vibrational spectroscopy as an identification tool for phyllosilicates (chrysotile, antigorite, talc, clinochlore, cymrite, montmorillonite, muscovite, phlogopite, biotite and sheridanite) from R. Macedonia are presented in Refs. [66] and [109]. In this review the results related to the study of all ten phyllosilicates (sheet silicates) will be discussed together to summarize the results and bring clearer insight of the vibrational spectral characteristics of this geologically important mineral group.

In order to confirm and make full their identification and characterization, the results obtained by vibrational spectroscopy for the ten studied sheet silicate minerals were amended with XRPD analysis as well as chemical analysis.

\subsubsection{Vibrational spectra}

\section{Chrysotile, $\mathrm{Mg}_{3} \mathrm{Si}_{2} \mathrm{O}_{5}(\mathrm{OH})_{4}$}

As in the spectra of other studied minerals, chrysotile depicted three well-separated IR spectral regions (Figs. 5a and 6a). The first group of bands appeared in the $3800-3600 \mathrm{~cm}^{-1}$ region, the second at $1200-800 \mathrm{~cm}^{-1}$ and the third region included the bands below $800 \mathrm{~cm}^{-1}$. Two bands observed at 3688 (strong) and $3646 \mathrm{~cm}^{-1}$ (weak) appeared in the highest-frequency region (Fig. 5a) and according to Viti and Mellini [77] are assigned as inner and outer $\mathrm{OH}$ stretching vibrations (see Table 2 in Ref. [66]). These two bands could be attributed to the possible presence of two crystallographically different $\mathrm{OH}$ groups in the chrysotile structure.

The bands at 1078, 1022 and $961 \mathrm{~cm}^{-1}$ are prescribed to vibrations of the $\mathrm{SiO}_{4}$ tetrahedra (Table 2 in Ref. [66]). Precisely, the first band (1078 $\mathrm{cm}^{-1}$ ) is attributed to $\mathrm{Si}-\mathrm{O}-\mathrm{Si}$ stretching vibrations, perpendicular to the basal plane, whereas the shoulder at $1022 \mathrm{~cm}^{-1}$ and the most intense band at $961 \mathrm{~cm}^{-1}$ arise from $\mathrm{Si}-\mathrm{O}-\mathrm{Si}$ vibrations in the basal plane [77].

The assignments of the bands registered below $800 \mathrm{~cm}^{-1}$ in the vibrational (IR and Raman) spectra of chrysotile and the other studied minerals could not be delivered without detailed studies, for example, isotope substitution and the dilution technique. Furthermore, the bands from different vibrational modes (that also appeared in this region) were often overlapped and overlaid. Therefore, the band assignments in this region are only tentative. However, the origin of the bands at 611 and $438 \mathrm{~cm}^{-1}$ in the IR spectrum of chrysotile (observed also by all four groups of authors [77-80]), accompanied with several shoulders, could be somewhat clearer, being attributed to the bending vibrations of $\mathrm{OH}$ groups and $\mathrm{SiO}_{4}$ tetrahedra, respectively. 


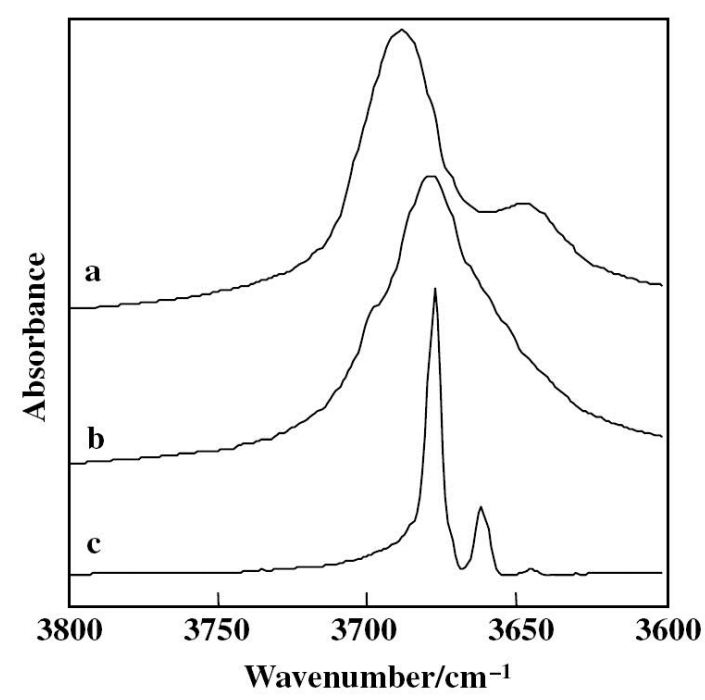

Fig. 5. IR spectra of chrysotile (a), antigorite (b) and talc (c) in the $\mathrm{OH}$ stretching region $\left(3800-3600 \mathrm{~cm}^{-1}\right)$

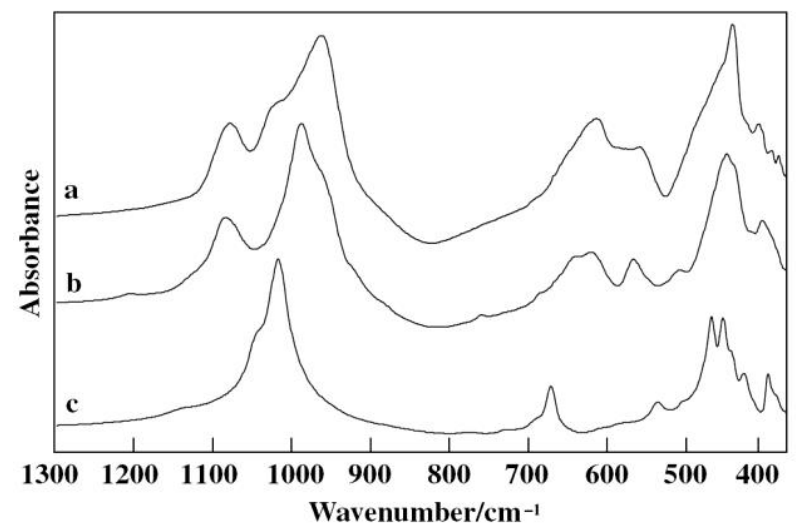

Fig. 6. IR spectra of chrysotile (a), antigorite (b) and talc (c) in the $\mathrm{SiO}_{4}$ region $\left(1300-370 \mathrm{~cm}^{-1}\right)$

Two different excitation lines (514 and 1064 $\mathrm{nm})$ were used to record the Raman spectra of chrysotile (Fig. 7a and b), in order to confirm the identification of chrysotile as well as to check the reproducibility of its Raman spectrum. In general, the spectra were similar (except in the regions around $950 \mathrm{~cm}^{-1}$ and below $150 \mathrm{~cm}^{-1}$ ) (see Table 3 in Ref. [66]) and in agreement with the corresponding literature data [91, 92].

The band in the $\mathrm{SiO}_{4}$ region observed at 1106 $\mathrm{cm}^{-1}$ arises from the antisymmetric stretching vibrations of $\mathrm{Si}-\mathrm{O}_{\mathrm{nb}}-\mathrm{Si}$ groups ( $\mathrm{nb}$ - non-bridging oxygen) [91]. As mentioned before, the Raman spectrum excited with $514 \mathrm{~nm}$ (Fig. 7a) exhibited a strong band at $944 \mathrm{~cm}^{-1}$, which was not registered in the Raman spectrum excited with $1064 \mathrm{~nm}$ (Fig. 7b) or in the spectra studied by Rinaudo et al. [91] and Kloprogge et al. [92]. Its origin is still not elucidated.

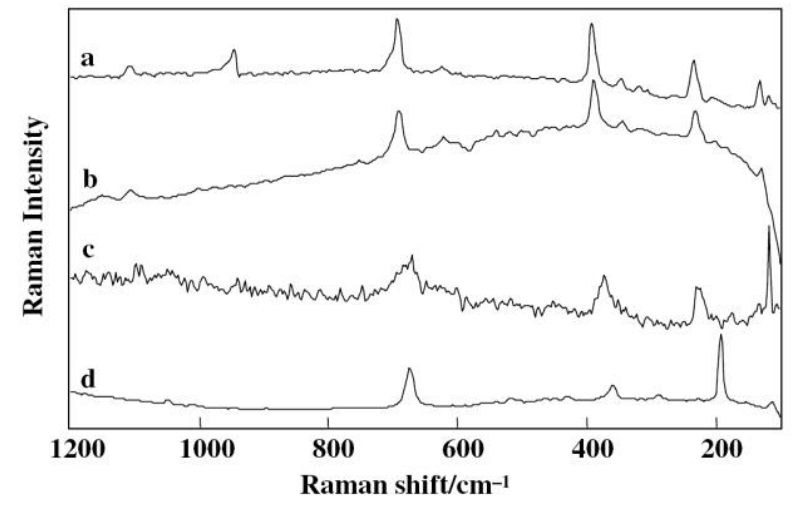

Fig. 7. Raman spectra of chrysotile (a, b) excited with 514 and $1064 \mathrm{~nm}$ lines, respectively. Raman spectra of antigorite (c) and talc (d) excited with 514 and $1064 \mathrm{~nm}$ lines, respectively $\left(1200-100 \mathrm{~cm}^{-1}\right)$

In both Raman spectra of chrysotile, two bands were observed around 625 and $692 \mathrm{~cm}^{-1}$ (Fig. 7a and b). As already mentioned in the literature [92], the band around $625 \mathrm{~cm}^{-1}$ appears from the stretching $\mathrm{Mg}-\mathrm{OH}$ mode, whereas the strong band at $692 \mathrm{~cm}^{-1}$ probably originates from the symmetric stretching mode of $\mathrm{Si}-\mathrm{O}-\mathrm{Si}$ groups. The bands below $400 \mathrm{~cm}^{-1}$ (around 390, 350, 320, 305, 235,205 and $130 \mathrm{~cm}^{-1}$ ) are, in general, in agreement with the literature data [91, 92]. The first four arise from bending $\mathrm{Si}-\mathrm{O}-\mathrm{Si}$ vibrations, whereas the band at $235 \mathrm{~cm}^{-1}$ is due to the vibrations of $\mathrm{O}_{\mathrm{nb}} \cdots \mathrm{H}-\mathrm{O}$ groups [91]. The peak at $206 \mathrm{~cm}^{-1}$ arises from the stretching $\mathrm{Mg}-\mathrm{O}$ mode (with $\mathrm{A}_{1 g}$ symmetry) of the distorted $\mathrm{MgO}_{6}$ octahedra [92].

$$
\text { Antigorite, }\left(\mathrm{Mg}_{\mathrm{Fe}} \mathrm{e}^{2+}\right)_{3} \mathrm{Si}_{2} \mathrm{O}_{5}(\mathrm{OH})_{4}
$$

The antigorite IR spectrum (Figs. 5b and 6b) showed expressed similarity with the spectrum of isomorphous chrysotile (antigorite contains a certain amount of $\mathrm{Fe}^{2+}$, see Table 1). The strong band at $3678 \mathrm{~cm}^{-1}$ and the shoulder at $3699 \mathrm{~cm}^{-1}$ are in accordance with the bands registered by Farmer [79] and Mellini et al. [82], but not in complete agreement with those observed by Taylor et al. [78] and Stubičan and Roy [81]. These bands are attributed to the stretching vibrations of $\mathrm{OH}$ groups bonded to $\mathrm{Mg}$ in octahedral coordination [82] (Table 4 in Ref. [66]). Similarly to the case of chrysotile, these highest energy bands, which were not well resolved, could arise from the presence of two crystallographically different $\mathrm{OH}$ groups in the structure of antigorite. 
Two strong bands observed at 1083 and 987 $\mathrm{cm}^{-1}$ and the shoulder at $958 \mathrm{~cm}^{-1}$ are in agreement with the literature data (Table 4 in Ref. [66]). The highest energy band arises from $\mathrm{Si}-\mathrm{O}_{\mathrm{nb}}-\mathrm{Si}$ stretching vibration, whereas the band at $987 \mathrm{~cm}^{-1}$ is due to $\mathrm{Si}-\mathrm{O}_{\mathrm{b}}-\mathrm{Si}$ stretching vibration [82]. The shoulder at $958 \mathrm{~cm}^{-1}$ probably implies a slightly different structural $\mathrm{Si}-\mathrm{O}-\mathrm{Si}$ bridging configuration in this mineral [82].

Several bands with medium and strong intensity were registered in the lower spectral region (see Table 4 in Ref. [66]). The band at $618 \mathrm{~cm}^{-1}$ and the shoulder at $639 \mathrm{~cm}^{-1}$ arise from deformations of $\mathrm{R}^{2+} \mathrm{O}-\mathrm{H}$ bonds $\left(\mathrm{R}^{2+}\right.$ mainly $\mathrm{Mg}$ ), the first from inner and the second from external $\mathrm{O}-\mathrm{H}$ bonds. The band with medium intensity at 564 $\mathrm{cm}^{-1}$ could be ascribed to bending $\mathrm{SiO}_{4}$ vibrations [82], whereas the strong band at $445 \mathrm{~cm}^{-1}$, according to Farmer [79], originates from bending $\mathrm{SiO}_{4}$ vibration associated with an $\mathrm{OH}$ translational vibration (Table 4 in Ref. [66]).

The Raman spectrum of antigorite excited with a $514 \mathrm{~nm}$ laser is presented in Fig. 7c (the antigorite spectrum with a $1064 \mathrm{~nm}$ line was of unsatisfactory quality). Similar to the IR spectra, the intensity and frequencies of the antigorite Raman bands were generally similar to those observed in the Raman spectrum of chrysotile. The bands due to antisymmetric stretching $\mathrm{Si}-\mathrm{O}-\mathrm{Si}$ modes characterize the $1200-1000 \mathrm{~cm}^{-1}$ Raman spectral region. Namely, three weak bands were registered at 1099, 1090 and $1048 \mathrm{~cm}^{-1}$, whereas only the latter one was found in the studied antigorite spectrum by Rinaudo et al. [91] (Table 5 in Ref. [66]).

The bands registered in the lower wavenumber region $\left(700-230 \mathrm{~cm}^{-1}\right)$ are in accordance with the literature data [91]. The symmetric stretching vibrations of $\mathrm{Si}-\mathrm{O}-\mathrm{Si}$ groups give rise to the band at $682 \mathrm{~cm}^{-1}$, whereas $\mathrm{v}(\mathrm{Mg}-\mathrm{OH})$ modes are manifested by the weak band at $628 \mathrm{~cm}^{-1}$. The slight shift of the latter band compared to the same band in the Raman spectrum of chrysotile (626 $\mathrm{cm}^{-1}$ ) could be due to higher content of $\mathrm{Fe}$ or $\mathrm{Al}$ in the octahedral sheets [91]. The band at $372 \mathrm{~cm}^{-1}$ is more likely assigned as a bending $\mathrm{Si}-\mathrm{O}-\mathrm{Si}$ vibration. Similarly, as in case with chrysotile, the band at $230 \mathrm{~cm}^{-1}$ could be prescribed to the vibrations of $\mathrm{O}_{\mathrm{nb}} \cdots \mathrm{H}-\mathrm{O}$ groups (Table 5 in Ref. [66]). Two additional peaks at 224 (medium) and $116 \mathrm{~cm}^{-1}$ (strong) registered in our Raman spectrum (Fig. 7c) were not observed in the Raman spectrum studied by Rinaudo et al. [91]. The bands are probably due to lattice modes.

\section{Talc, $\left(\mathrm{Mg} \mathrm{Fe}^{2+}\right)_{3} \mathrm{Si}_{4} \mathrm{O}_{10}(\mathrm{OH})_{2}$}

In Figures $5 c$ and $6 c$ is presented the IR spectrum of the sample contemplated as talc, whereas band assignments are given in Table 6 of Ref. [66]. The main characteristic is the presence of sharp bands (Figs. 5c and 6c), a result of the high crystallinity of its structure. Namely, three sharp bands with different intensity were registered at 3677,3661 and $3644 \mathrm{~cm}^{-1}$ in accordance with the data published by Vedder [86], but not in complete agreement with Taylor et al. [78] and Nicodom [83] (one band observed) and Smolander et al. [85] (two bands). In an ideal talc composition, $\mathrm{Mg}_{3} \mathrm{Si}_{4} \mathrm{O}_{10}(\mathrm{OH})_{2}$, one sharp $\mathrm{OH}$ stretching band should be expected due to the complete occupancy of the octahedral layer by $\mathrm{Mg}$ cations. The presence of three bands in the $\mathrm{OH}$ stretching region of talc could be explained similarly as was done in our previous IR study on amphiboles [23] where, depending on the presence of $\mathrm{Fe}^{2+}$ and $\mathrm{Mg}^{2+}$ cations in Y structural sites, the number of bands in the $\mathrm{OH}$ stretching region could vary from one (if only $\mathrm{Fe}^{2+}$ is present) to four (if an almost equal content of $\mathrm{Mg}^{2+}$ and $\mathrm{Fe}^{2+}$ is present). The three bands mentioned in the spectrum of talc (Fig. 5c) are attributed to stretching $\mathrm{OH}$ vibrations where the closest octahedral sites are occupied by $3 \mathrm{Mg}^{2+}$, $2 \mathrm{Mg}^{2+}+\mathrm{Fe}^{2+}$ and $\mathrm{Mg}^{2+}+2 \mathrm{Fe}^{2+}$ cation combinations: $\left[\mathrm{Mg}^{2+}, \mathrm{Mg}^{2+}, \mathrm{Mg}^{2+}\right]-\mathrm{OH},\left[\mathrm{Mg}^{2+}, \mathrm{Mg}^{2+}\right.$, $\left.\mathrm{Fe}^{2+}\right]-\mathrm{OH}$ and $\left[\mathrm{Mg}^{2+}, \mathrm{Fe}^{2+}, \mathrm{Fe}^{2+}\right]-\mathrm{OH}$, respectively. It is in agreement with the possibility of replacing $\mathrm{Mg}^{2+}$ by $\mathrm{Fe}^{2+}$ in the octahedral layer [86].

The strong band at $1018 \mathrm{~cm}^{-1}$ and the shoulder at $1047 \mathrm{~cm}^{-1}$ were assigned as $v_{1}(\mathrm{Si}-\mathrm{O}-\mathrm{Si})$ and $v_{3}(\mathrm{Si}-\mathrm{O}-\mathrm{Si})$ modes, respectively [84]. Additionally, the very weak bands at 774 and $728 \mathrm{~cm}^{-1}$ were also found in the studied spectrum by Smolander $e t$ al. [85], but are not registered by other authors [78, 83, 84]. Their origin is still unknown. According to Russell et al. [84] the strong band at $669 \mathrm{~cm}^{-1}$ arises from $\mathrm{OH}$ librations.

In the $600-400 \mathrm{~cm}^{-1}$ region three bands were registered at 533, 465 and $450 \mathrm{~cm}^{-1}$ and are in agreement with the literature data [78, 83-85] (Table 6 in Ref. [66]). The highest-frequency one probably originates from the $v(\mathrm{M}-\mathrm{OH})$ vibration that involves the octahedral cations and hydroxyl groups, whereas the second and the third bands at 465 and $450 \mathrm{~cm}^{-1}$ more likely appear from the translational vibrations of $\mathrm{OH}$ groups and $\mathrm{Si}-\mathrm{O}-\mathrm{Si}$ bending, respectively [84].

The interpretation of its Raman spectrum recorded using a $1064 \mathrm{~nm}$ excitation line (Fig. 7d) was the next step in the identification of the talc 
sample from Ržanovo. The weak band at 1048 $\mathrm{cm}^{-1}$ was assigned as stretching vibrations of $\mathrm{Si}-$ $\mathrm{O}_{\mathrm{nb}}-\mathrm{Si}$ groups [93] (Table 7 in Ref. [66]). The characteristic feature in the $680-450 \mathrm{~cm}^{-1}$ region is the strong band at $675 \mathrm{~cm}^{-1}$ prescribed to the symmetric Si-O-Si stretching mode [93]. The lowerfrequency peaks in the Raman spectrum of talc were characterized with weak to medium intensity and could be prescribed to stretching $\mathrm{Mg}-\mathrm{O}$ vibrations (430, 289 and $228 \mathrm{~cm}^{-1}$ ) and deformation modes of the silicate network $\left(517\right.$ and $\left.361 \mathrm{~cm}^{-1}\right)$. The bands at 193 and $114 \mathrm{~cm}^{-1}$ are most likely from lattice modes [93] (Table 7 in Ref. [66]).

\section{Clinochlore, $\left(\mathrm{Mg}, \mathrm{Fe}^{2+}\right)_{5} \mathrm{Si}_{3}(\mathrm{Al}, \mathrm{Cr})_{2} \mathrm{O}_{10}(\mathrm{OH})_{8}$}

The clinochlore mineral belongs to the group of trioctahedral chlorites and presents an endmember of the series of chlorite-chamosite solid solutions. Namely, if the octahedral sites in the structure are mainly occupied with $\mathrm{Mg}^{2+}$ cations, the mineral is known as Mg-rich chlorite (clinochlore), whereas if the $\mathrm{Mg}^{2+}$ ions are substituted by $\mathrm{Fe}^{2+}$ cations, the mineral is recognized as chamosite (the other endmember of the series) [110].

In Figures 8a and 9a is presented the infrared spectrum of clinochlore and the band assignments are given in Table 8 of Ref. [66]. The appearance of three bands due to $v(\mathrm{OH})$ stretching vibrations (Fig. 8a) corresponds to the same number of crystallographically different $\mathrm{OH}$ groups present in its structure. The highest-frequency band (with weak intensity) found at $3675 \mathrm{~cm}^{-1}$ arises from the vibrations of $\mathrm{OH}$ groups not involved in hydrogen bonds ( $\mathrm{OH}$ groups from 2:1 layer). The remaining two bands, which were more intense (at 3583 and $3428 \mathrm{~cm}^{-1}$ ) were ascribed to hydroxyl groups involved in hydrogen bonds, $(\mathrm{SiSi}) \mathrm{O} \cdots \mathrm{HO}$ and $(\mathrm{SiAl}) \mathrm{O} \cdots \mathrm{HO}$, respectively [88].

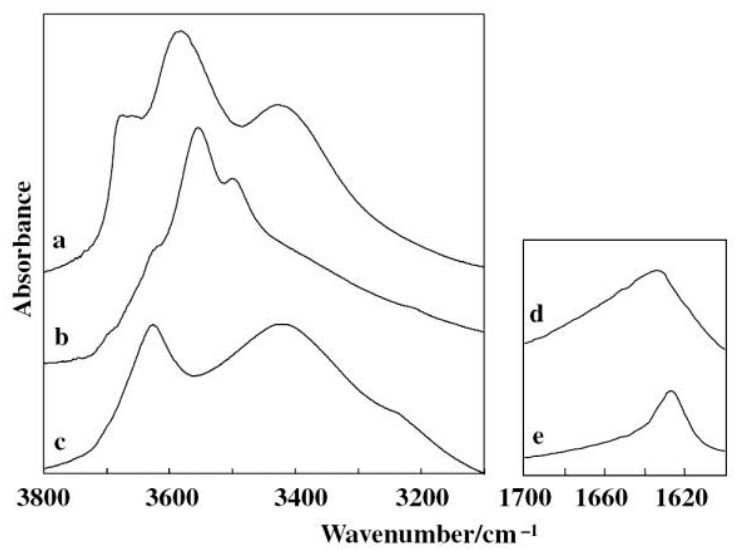

Fig. 8. IR spectra of clinochlore (a), cymrite (b) and montmorillonite (c) in the $v(\mathrm{OH})$ and $v\left(\mathrm{H}_{2} \mathrm{O}\right)$ regions. The $\delta\left(\mathrm{H}_{2} \mathrm{O}\right)$ bands in cymrite (d) and montmorillonite (e).

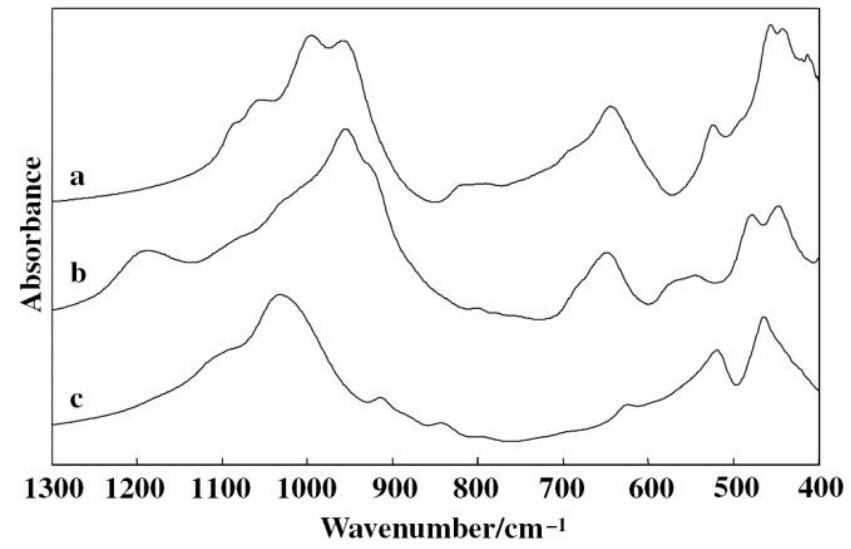

Fig. 9. IR spectra of clinochlore (a), cymrite (b) and montmorillonite (c) in the $\mathrm{SiO}_{4}$ region $\left(1300-370 \mathrm{~cm}^{-1}\right)$

Two very strong bands (996 and $958 \mathrm{~cm}^{-1}$ ) and two shoulders (1086 and $1059 \mathrm{~cm}^{-1}$ ) were registered in the $1100-900 \mathrm{~cm}^{-1}$ spectral region (found also by all three groups of authors $[85,87$, 88]) and are assigned as stretching vibrations of $\mathrm{SiO}_{4}$ tetrahedra (Fig. 9a and Table 8 in Ref. [66]). The weak bands at 818 and $791 \mathrm{~cm}^{-1}$ could be associated with tetrahedral $\mathrm{Al}-\mathrm{O}$ stretching and according to Farmer [79] their intensity increases with increasing $\mathrm{Al}$ for $\mathrm{Si}$ substitution. Here, it is most likely that this substitution in the studied clinochlore specimen was probably low because of the very weak intensity of the mentioned bands. Metal-hydroxyl libration and translation give rise to the bands at 644 and $457 \mathrm{~cm}^{-1}$, respectively, whereas the very strong band at $442 \mathrm{~cm}^{-1}$, registered only in the spectrum studied by Gopal et al. [87], is due to $\mathrm{Si}-\mathrm{O}-\mathrm{Si}$ bending vibration (Table 8 in Ref. [66]).

The Raman spectrum in the $1200-100 \mathrm{~cm}^{-1}$ region was characterized by the presence of welldefined peaks (Fig. 10a and Table 9 in Ref. [66]). The highest-frequency peaks at 1089 and 1059 $\mathrm{cm}^{-1}$, observed also by Prieto et al. [88] but not registered by Kleppe et al. [94], are attributed to antisymmetric $\mathrm{Si}-\mathrm{O}-\mathrm{Si}$ stretching modes. The symmetric $\mathrm{Si}-\mathrm{O}-\mathrm{Si}$ stretching appears as strong bands at 679 and $540 \mathrm{~cm}^{-1}$ registered by all three groups of authors $[87,88,94]$. The doublet at 459 and $440 \mathrm{~cm}^{-1}$ (not registered by Gopal et al. [87] and Kleppe et al. [94]) and the strong band at 354 $\mathrm{cm}^{-1}$ probably arise from librational $\mathrm{OH}$ (the first one) and bending $\mathrm{Si}-\mathrm{O}-\mathrm{Si}$ modes. According to Prieto et al. [88], the intensity of the latter band $\left(354 \mathrm{~cm}^{-1}\right)$ decreases with $\mathrm{Al}$ substituting $\mathrm{Si}$.

The bands that appeared in the lowest wavenumber region are generally in accordance with the literature data $[87,88,94]$ (Table 9 in Ref. [66]). The band at $285 \mathrm{~cm}^{-1}$ was prescribed to tet- 
rahedral movements with the symmetry species $\mathrm{E}_{1}^{3}$, whereas the sharp peak at $199 \mathrm{~cm}^{-1}$ was ascribed as $v(\mathrm{M}-\mathrm{O})$ vibration of the $\mathrm{MO}_{6}$ octahedra $(\mathrm{M}=\mathrm{Mg}$ and $\mathrm{Fe})$ [88]. The latter two bands (118 and $106 \mathrm{~cm}^{-1}$ ) observed in the Raman spectrum (Fig. 10a) could be prescribed to translational $\mathrm{Si}-$ O-Si modes [87].

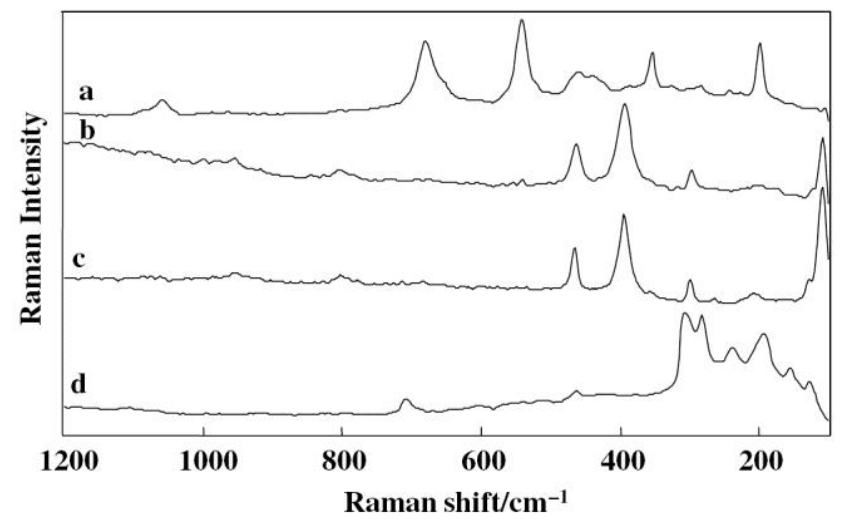

Fig. 10. Raman spectra of clinochlore (a) excited with a 1064 $\mathrm{nm}$ line, cymrite (b and c) excited with 1064 and $514 \mathrm{~nm}$ lines, respectively, and montmorillonite (d) excited with $1064 \mathrm{~nm}$ line $\left(1200-100 \mathrm{~cm}^{-1}\right)$

\section{Cymrite, $\mathrm{BaAl}_{2} \mathrm{Si}_{2} \mathrm{O}_{8} \cdot \mathrm{H}_{2} \mathrm{O}$}

Comparison of the IR and Raman spectra of the studied sample of cymrite from Nežilovo with the corresponding literature data has shown that it represents the Ba-cymrite type. An attempt to interpret its IR spectrum (Figs. 8b and d and 9b) was made since, to our knowledge, no IR band assignment has been found in the literature (except for the $\mathrm{OH}$ stretching region). Thus, the peaks at 3620 , 3555 and $3498 \mathrm{~cm}^{-1}$ are prescribed to $\mathrm{H}_{2} \mathrm{O}$ stretching vibrations (Fig. 8b), whereas the sharp band with medium intensity at $1627 \mathrm{~cm}^{-1}$ originates from $\delta\left(\mathrm{H}_{2} \mathrm{O}\right)$ vibrations (Fig. 8d), suggesting that one type of crystallographically different water molecule is present in the structure of cymrite.

The Si-O-Si stretching vibrations were represented by four bands (1188, 1031, 955 and 921 $\mathrm{cm}^{-1}$ ). Their wavenumbers and intensities (except for the shoulder at $1031 \mathrm{~cm}^{-1}$ ) are in good agreement with the corresponding bands in the published, but not discussed, IR spectrum of cymrite [89]. Tentative assignment of the bands in the lower IR spectral region could be derived by analogy with the bands appearing in the IR spectra of the other studied sheet silicates (related to their common structural features) as well as by the spectral differences which appeared as a result of the presence of water molecules in the cymrite structure. Taking into account the previous assignment of the
$644 \mathrm{~cm}^{-1}$ band to $\mathrm{M}-\mathrm{OH}$ librations in the clinochlore IR spectrum (Fig. 9a, Table 8 in Ref. [66]), the band at $648 \mathrm{~cm}^{-1}$ in the corresponding cymrite spectrum could be attributed to $\mathrm{Ba}-\mathrm{OH}$ librations (Fig. 9b). Furthermore, the band at $478 \mathrm{~cm}^{-1}$ and the shoulder at $568 \mathrm{~cm}^{-1}$ presumably originate from librational $\mathrm{H}_{2} \mathrm{O}$ modes (Table 10 in Ref. [66]). The bands at 544 and $447 \mathrm{~cm}^{-1}$ appear from $\mathrm{Si}-\mathrm{O}-\mathrm{Si}$ deformations.

Two different excitation lasers (Figs. 10b and c) were used to record the Raman spectrum of cymrite. All peaks were found at almost identical frequencies and similar intensities in both Raman spectra (1064 and $514 \mathrm{~nm}$ ) (Table 10 in Ref. [66]). To our knowledge, assignments of the Raman bands for cymrite have not yet been suggested. Thus, assignment of the bands in our cymrite spectrum was based on comparison with the IR spectrum of cymrite as well as the Raman spectra of other studied minerals. Namely, the $\mathrm{SiO}_{4}$ stretching region is characterized by the presence of weak bands at 955 and $802 \mathrm{~cm}^{-1}$ due to $v_{3}(\mathrm{Si}-\mathrm{O}-\mathrm{Si})$ and $v_{1}(\mathrm{Si}-\mathrm{O}-\mathrm{Si})$ modes, respectively. The strong peaks at 464 and $394 \mathrm{~cm}^{-1}$, also registered but not discussed in the published spectrum by Graham et al. [89], probably arise from $\mathrm{H}_{2} \mathrm{O}$ librations and $\delta(\mathrm{Si}-$ O-Si) modes, respectively. The bands at 298, 125 and $108 \mathrm{~cm}^{-1}$ can be tentatively prescribed to $v(\mathrm{Ba}-\mathrm{O})$ vibrations (the first one) and external lattice modes (Table 10 in Ref. [66]).

\section{Montmorillonite \\ $(\mathrm{K}, \mathrm{Ca})_{0.3}(\mathrm{Al}, \mathrm{Mg})_{2} \mathrm{Si}_{4} \mathrm{O}_{1 \mathrm{O}}(\mathrm{OH})_{2} \cdot \mathrm{nH}_{2} \mathrm{O}$}

The montmorillonite IR spectrum is presented in Figures 8c, 8e and 9c, whereas tentative assignment of the bands is given in Table 11 of Ref. [66]. Going from the $\mathrm{OH}$ and $\mathrm{H}_{2} \mathrm{O}$ stretching region, two complex and broad bands at 3626 and $3421 \mathrm{~cm}^{-1}$ appeared, additionally associated with one shoulder at the lower-frequency side 3233 $\mathrm{cm}^{-1}$ (Fig. 8c, Table 11 in Ref. [66]). The broadening of the bands in this region is presumably due to the presence of hydrogen bonding in the montmorillonite structure. According to Farmer and Russell [90], the band at $3626 \mathrm{~cm}^{-1}$ arises from hydroxyl stretching vibrations. The more complex and intensive band at $3421 \mathrm{~cm}^{-1}$ is apparently due to water stretching. The shoulder at $3233 \mathrm{~cm}^{-1}$ could be prescribed to an overtone of the $\delta\left(\mathrm{H}_{2} \mathrm{O}\right)$ vibration found at $1630 \mathrm{~cm}^{-1}$ (Fig. $8 \mathrm{c}$ and e).

The shoulder at $1104 \mathrm{~cm}^{-1}$ (from $\mathrm{Si}-\mathrm{O}-\mathrm{Si}$ stretching vibration perpendicular to the plane of the layer) and the strong broad band at $1031 \mathrm{~cm}^{-1}$ (from in-plane $\mathrm{Si}-\mathrm{O}-\mathrm{Si}$ stretching vibration) are in 
agreement with the literature data [81, 90] (Table 11 in Ref. [66]). The $\mathrm{OH}$ librations appear as weak bands positioned at 913 and $843 \mathrm{~cm}^{-1}$, the former ascribed as the libration of $\mathrm{OH}$ coordinated to $\mathrm{AlAl}$ pairs, the latter as libration of $\mathrm{OH}$ coordinated to AlMg pairs [84]. The very weak band at $625 \mathrm{~cm}^{-1}$ could not be accurately assigned, but one probability is that it originates from the translational modes of hydroxyl groups [90]. In the $550-400 \mathrm{~cm}^{-1}$ spectral region strong absorption bands at 519 and $464 \mathrm{~cm}^{-1}$ were observed close to the wavenumbers of the bands registered by Farmer and Russell [90] and Stubičan and Roy [81]. These bands presumably appear as result of bending $\mathrm{Si}-\mathrm{O}-\mathrm{Si}$ vibrations and translational modes of the octahedral ions and their adjacent oxygen layers.

The Raman spectrum of montmorillonite (recorded with a $1064 \mathrm{~nm}$ excitation line) is presented in Fig. 10d and band assignments are listed in Table 11 of Ref. [66]. The bands that appear in the lower energy region $\left(350-100 \mathrm{~cm}^{-1}\right.$ ) were characterized by medium or strong intensity (Fig. 10d). In sharp contrast, the higher wavenumber region (1110-700 $\mathrm{cm}^{-1}$ ) was represented by four weak bands prescribed to the $v_{3}(\mathrm{Si}-\mathrm{O}-\mathrm{Si})$ mode $\left(1105 \mathrm{~cm}^{-1}\right)$, wagging vibrations of $\mathrm{OH}$ groups attached to $\mathrm{Al}\left(911\right.$ and $\left.799 \mathrm{~cm}^{-1}\right)$ and $v_{1}(\mathrm{Si}-\mathrm{O}-\mathrm{Si})$ mode $\left(708 \mathrm{~cm}^{-1}\right)$ [95].

The bands registered at 463 and $432 \mathrm{~cm}^{-1}$ (registered also by Frost and Rintoul [95]) are likely to appear from bending $\mathrm{Si}-\mathrm{O}-\mathrm{Si}$ modes and librational $\mathrm{OH}$ modes, respectively. In the 300-200 $\mathrm{cm}^{-1}$ Raman spectral region three bands were registered at 307,282 and $239 \mathrm{~cm}^{-1}$, the first and third ones not observed by Frost and Rintoul [95] (Table 11 in Ref. [66]). The second and the third bands were assigned as $v_{1}\left(A_{1}\right)$ and $v_{3}\left(B_{2}\right)$ vibrational modes of the $\mathrm{O}-\mathrm{H} \cdots \mathrm{O}$ triangle, respectively. These vibrations would be expected when an interaction between the inner hydroxyl groups of dioctahedral montmorillonite and adjacent oxygens occurs. On the other hand, bands below $200 \mathrm{~cm}^{-1}$, generally, appear from vibrations of the distorted $\mathrm{AlO}_{6}$ octahedron and from $\mathrm{Si}_{2} \mathrm{O}_{5}$ ring breathing mode (Table 11 in Ref. [66]).

\section{Muscovite, $\mathrm{KAl}_{2}\left(\mathrm{Si}_{3} \mathrm{Al}\right) \mathrm{O}_{10}(\mathrm{OH}, \mathrm{F})_{2}$}

The IR absorption spectra in the region from 4000 to $400 \mathrm{~cm}^{-1}$ (Fig. 11a and b) as well as the Raman spectra in the $1200-110 \mathrm{~cm}^{-1}$ region (Fig. $12 \mathrm{a}-\mathrm{d})$ of the powdered muscovite and the mineral initially designated as paragonite (according to the morphological features) were studied together in order to demonstrate their resemblance. However, the absence of $\mathrm{Na}$ according to the chemical analysis of the sample from Nežilovo (wt $\%, \mathrm{~K}_{2} \mathrm{O}-$ 10.13; $\mathrm{Na}_{2} \mathrm{O}<0.01 ; \mathrm{MgO}-1.02 ; \mathrm{CaO}<0.01 ; \mathrm{FeO}$ - 4.76; $\mathrm{SiO}_{2}-48.12 ; \mathrm{TiO}_{2}-0.38 ; \mathrm{MnO}-0.40$; $\mathrm{Al}_{2} \mathrm{O}_{3}$ - 23.72) confirmed that the studied sample was muscovite (not paragonite). Furthermore, the results from the X-ray microprobe analysis were found to be similar to those obtained for the muscovite sample from Dunje (see Table 1, wt $\%, \mathrm{~K}_{2} \mathrm{O}$ - 11.19; $\mathrm{Na}_{2} \mathrm{O}<0.01 ; \mathrm{MgO}-2.56 ; \mathrm{CaO}<0.01$; $\mathrm{FeO}-4.03 ; \mathrm{SiO}_{2}-49.18 ; \mathrm{TiO}_{2}-0.37 ; \mathrm{MnO}<$ $\left.0.01 ; \mathrm{Al}_{2} \mathrm{O}_{3}-28.40\right)$.

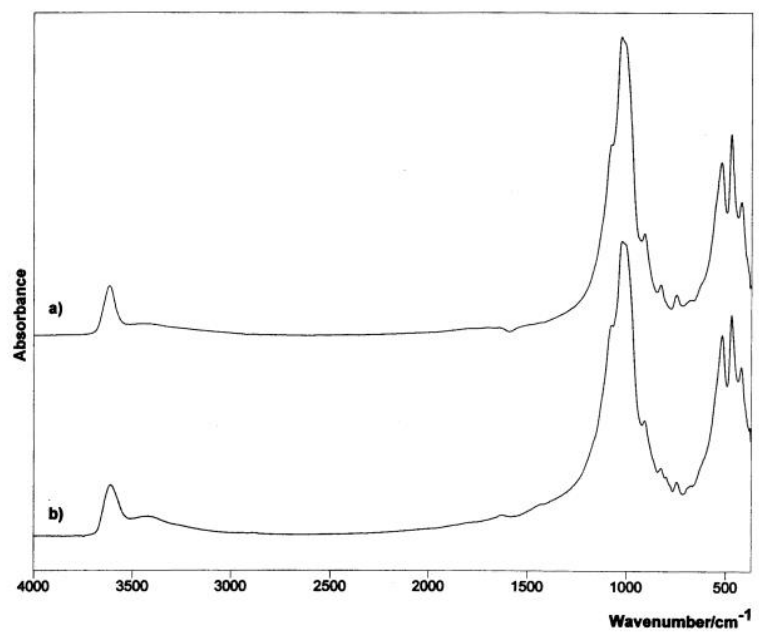

Fig. 11. FT IR spectra of muscovite from Dunje (a) and Nežilovo (b) obtained using $\mathrm{KBr}$ pellets

The IR spectra of the studied samples were practically identical and characterized by bands that appeared in two well-defined spectral regions originating from $\mathrm{OH}$ and $\mathrm{SiO}_{4}$ (including $\mathrm{MO}_{6}$ modes) vibrations, respectively (Fig. 11a and b). In the $\mathrm{OH}$ stretching region, a band with medium intensity was registered around $3610 \mathrm{~cm}^{-1}$ and attributed to the stretching vibrations of $\mathrm{OH}$ groups. In addition, a weak and broad band found around $3425 \mathrm{~cm}^{-1}$ originates from $\mathrm{H}_{2} \mathrm{O}$ stretching vibrations from adsorbed water. The presence of adsorbed water in both samples is also evident from the weak band around $1630 \mathrm{~cm}^{-1}$, ascribed to $\delta\left(\mathrm{H}_{2} \mathrm{O}\right)$ vibrations. The assignments of the IR bands as well as their comparison with the literature data are given in Table 2 of Ref. [109].

The band assignment in the vibrational region below $1150 \mathrm{~cm}^{-1}$ (for all studied minerals) is, to some extent, tentative because the investigations could not be carried out in detail without further experiments (for example, the use of isotope substitution and the dilution technique). However, the bands in the $1150-950 \mathrm{~cm}^{-1}$ are attributed to 
stretching $\mathrm{Si}-\mathrm{O}-\mathrm{Si}$ or $\mathrm{Si}-\mathrm{O}-\mathrm{Al}$ modes [102] (although $\mathrm{Al}$ may replace $\mathrm{Si}$ in the tetrahedral sites, normally two consecutive tetrahedra are not, for geometrical considerations, occupied both by $\mathrm{Al}$, and the bonds are $\mathrm{Si}-\mathrm{O}-\mathrm{Si}$ or $\mathrm{Al}-\mathrm{O}-\mathrm{Si}$ ) whereas the bands in the $900-740 \mathrm{~cm}^{-1}$ region arise due to octahedral $\mathrm{Al}-\mathrm{O}$ and $\mathrm{Al}-\mathrm{O}-\mathrm{Al}$ stretching modes [103] (Table 2 in Ref. [109]). Shifting of the shoulder (1080-1065 $\left.\mathrm{cm}^{-1}\right)$ positioned on the higher-frequency side of the strongest IR band is explained by the compositional change of the mica going from muscovite to celadonite [103] (Table 2 in Ref. [109]). Taking into account this consideration and the appearance of the shoulder at $978 \mathrm{~cm}^{-1}$ could tentatively imply that the studied mineral composition is very close to muscovite. In addition, a noticeable wavenumber decrease (from 538-519 $\mathrm{cm}^{-1}$ ) of the bending $\mathrm{O}-\mathrm{Si}-\mathrm{O}$ vibration occurs as the composition becomes tetrasilicic [103]. The remaining two IR bands around 910 and $415 \mathrm{~cm}^{-1}$ appear from $\mathrm{Al}-\mathrm{OH}$ librational modes.

The Raman dispersive $(532 \mathrm{~nm})$ and FTRaman spectra (1064 nm excitation) of muscovite are presented in Fig. 12. The obtained results closely resemble the literature data [99-101] (Table 3 in Ref. [109]). Although the FT Raman spectrum (Fig. 12d) expressed a higher noise-to-signal ratio, it was similar to its dispersive counterpart (Fig. 12c).

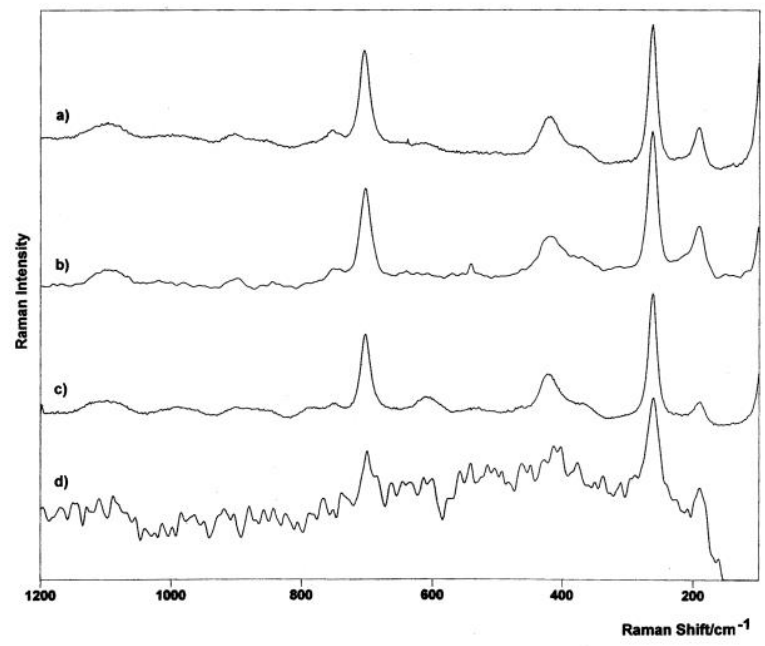

Fig. 12. Raman spectra of muscovite from Dunje ( $a$ and $b$ ) and Nežilovo (c and d) obtained using 532 and $1064 \mathrm{~nm}$ excitation lasers, respectively

The broad and complex band around 1100 $\mathrm{cm}^{-1}$ and the band around $900 \mathrm{~cm}^{-1}$ are assigned as stretching $\mathrm{Si}-\mathrm{O}-\mathrm{Si}(\mathrm{Al})$ vibrations (Table 3 in Ref. [109]). The very weak bands around 750 and 700 $\mathrm{cm}^{-1}$ probably arise from $\delta(\mathrm{O}-\mathrm{Al}-\mathrm{O})$ vibrations. The band at $541 \mathrm{~cm}^{-1}$ registered only in the FT-
Raman spectrum of muscovite from Dunje (Fig. 12d) according to McKeown et al. [100] has $\mathrm{Al}-$ $\mathrm{O}-\mathrm{Al}$ bending character. The lower-frequency bands around 420 and $260 \mathrm{~cm}^{-1}$ could not be solely prescribed to one vibrational type and had a mixed character mainly associated to $\mathrm{O}-\mathrm{Al}-\mathrm{O}$ and $\mathrm{O}-\mathrm{Si}-$ $\mathrm{O}$ translations. The Raman peak at $190 \mathrm{~cm}^{-1}$ could be attributed to $\mathrm{Al}-\mathrm{OH}$ translations.

\section{Phlogopite, $\mathrm{KMg}_{3}\left(\mathrm{Si}_{3} \mathrm{Al}\right) \mathrm{O}_{10}(\mathrm{~F}, \mathrm{OH})_{2}$}

The IR spectrum of phlogopite in the 4000 $400 \mathrm{~cm}^{-1}$ region is presented in Figure 13a and band assignment is given in Table 4 of Ref. [109]. The observed very weak intensity of the $v(\mathrm{OH})$ band at $3705 \mathrm{~cm}^{-1}$ (Fig. 13a and b) compared to the corresponding band in the muscovite IR spectrum (Fig. 11a) is probably due to the difference in the molar $\mathrm{OH}$ absorption coefficients ( factor 3 ) between both minerals. Furthermore, a medium band registered at $1456 \mathrm{~cm}^{-1}$ (Fig. 13a) was neither expected nor observed in the corresponding literature data $[81,86,90,97,98,106,111]$ (Table 4 in Ref. [109]). It is explained by the presence of carbonate impurities in the sample supported by the fact that the band wavenumber strongly coincided with the maxima in the dolomite IR spectrum [112] shown in Figure 13e. After treatment of the phlogopite sample by $3 \mathrm{M} \mathrm{HCl}$, the carbonate phase was totally removed (Fig. 13b).

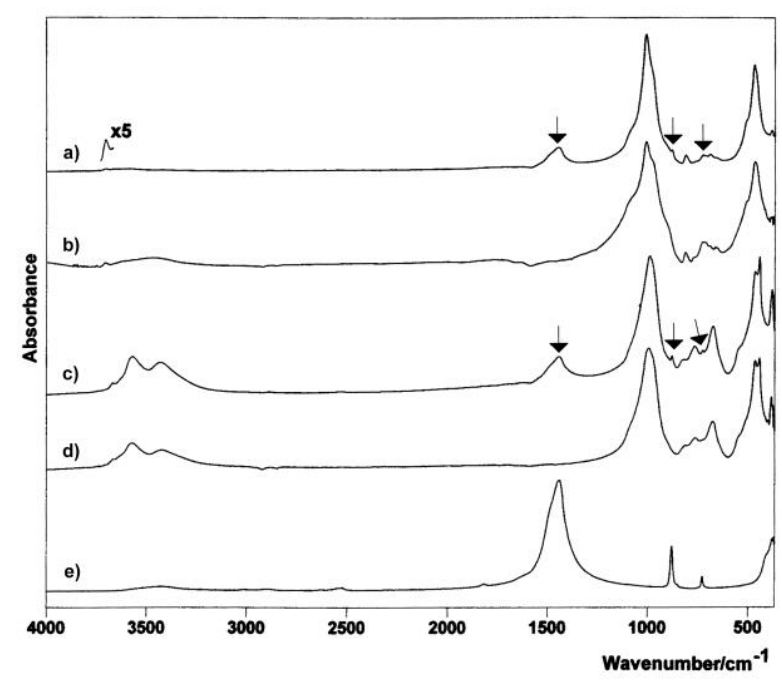

Fig. 13. FT IR spectra of phlogopite (a) and sheridanite (c) obtained using $\mathrm{KBr}$ pellets. The IR spectra of the samples after elimination of carbonate impurities (treatment by diluted $\mathrm{HCl}$ ) are given under (b) and (d), respectively. IR bands that appear from dolomite (e) impurity are marked with arrows.

The $\mathrm{Si}-\mathrm{O}-\mathrm{Si}$ stretching spectral region of phlogopite was characterized by two bands (1011 and $977 \mathrm{~cm}^{-1}$, Fig. 13a). In fact, the observed ab- 
sorption at $977 \mathrm{~cm}^{-1}$ represented a shoulder (overlapped with the band at higher frequency) whereas the literature reported a strong band [81, 86, 97, 98, 104] (Table 4 in Ref. [109]).

The observed weak bands in the lowerfrequency region (at 882, 813, 727 and $692 \mathrm{~cm}^{-1}$ ) were also registered (except for the first one) by other authors $[81,86,90,97,98,106]$ (Table 4 in Ref. [109]). The $882 \mathrm{~cm}^{-1}$ band appears from the $v_{2}\left(\mathrm{CO}_{3}{ }^{2-}\right)$ mode from the previously mentioned carbonate impurities (Fig. 13a), whereas the band at $813 \mathrm{~cm}^{-1}$ is probably associated with $\mathrm{Al}-\mathrm{O}$ vibrations of $\mathrm{AlO}_{4}$ tetrahedra [111]. On the other hand, the band at $727 \mathrm{~cm}^{-1}$ (overlapped with the $v_{4}\left(\mathrm{CO}_{3}{ }^{2-}\right.$ ) mode from the carbonate impurities) arises from $\mathrm{Al}-\mathrm{O}-\mathrm{Si}$ stretching vibrations [111] (Fig. 13c). The overlap was additionally confirmed by treating samples with diluted $\mathrm{HCl}$ solution (Fig. 13b). Namely, despite complete elimination of the bands originating from the carbonate phase (Fig. 13a vs. Fig. 13b), the absorbance near $730 \mathrm{~cm}^{-1}$ remained (Fig. 13b). The band at $692 \mathrm{~cm}^{-1}$ is attributed to symmetric $\mathrm{Si}-\mathrm{O}-\mathrm{Si}$ stretching vibration [81].

The absence of bands near $600 \mathrm{~cm}^{-1}$ from the $\mathrm{OH}$ librations (Fig. 13a) according to Farmer [111] is typical for fluorophlogopite although it might serve as an indication of the low $\mathrm{OH}$ molar absorption coefficient of phlogopite. The shoulder at $511 \mathrm{~cm}^{-1}$ and the band with very strong intensity at $470 \mathrm{~cm}^{-1}$ (Table 4 in Ref. [109]) are assigned as bending Si-O-Si modes [81, 86, 90, 97, 98, 106].

Three excitation lines $(514,532$ and 1064 $\mathrm{nm})$ were used to record the Raman spectrum of the phlogopite sample (Fig. 14a-c). The peaks in the studied region $\left(1200-100 \mathrm{~cm}^{-1}\right)$ were found at almost identical frequencies in all three spectra (Table 5 in Ref. [109]). The highest-wavenumber doublet (around 1100 and $1085 \mathrm{~cm}^{-1}$ ) appears from the strongest $v_{1}\left(\mathrm{CO}_{3}{ }^{2-}\right)$ mode of the carbonate impurities: calcite $\left(1086 \mathrm{~cm}^{-1}\right)$ and dolomite $(1095$ $\mathrm{cm}^{-1}$ ) (Fig. 14e and f).

It is evident that, compared to the broader IR bands, the narrow Raman bands make it possible to discriminate between calcite and dolomite carbonate impurities in the studied phlogopite sample. In this context, Raman spectroscopy enables differentiation between isomorphous minerals. The band at 1032 $\mathrm{cm}^{-1}$ (also observed by McKeown et al. [105] and Wopenka et al. [101]) is attributed to stretching $\mathrm{Si}-$ $\mathrm{O}-\mathrm{Si}$ vibrations. The most prominent feature in the $700-300 \mathrm{~cm}^{-1}$ region is the strong band around 680 $\mathrm{cm}^{-1}$. The broadening of its lower-frequency side (as compared with the corresponding band in the muscovite spectrum), could be taken as evidence for greater tetrahedral $\mathrm{Si} / \mathrm{Al}$ disorder in the phlogopite structure. This band probably arises from tetrahedral $\mathrm{O}-\mathrm{Si}(\mathrm{Al})-\mathrm{O}$ bending vibration (the tetrahedral sites are $75 \%$ occupied by $\mathrm{Si}$ while the remaining $25 \%$ contain $\mathrm{Al})$ [105].

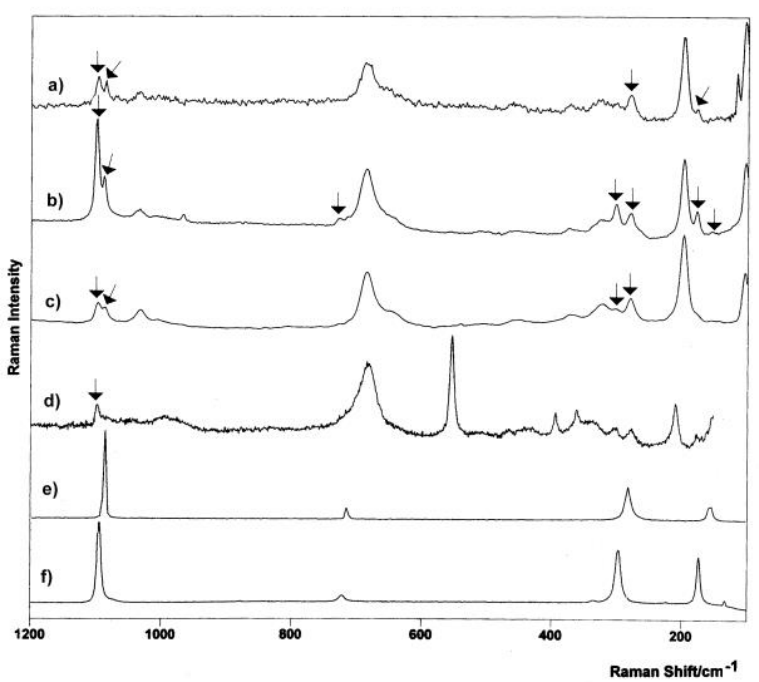

Fig. 14. Raman spectra of phlogopite $(a-c)$ obtained using 514, 532 and $1064 \mathrm{~nm}$ excitation lines, respectively, and sheridanite using a $514 \mathrm{~nm}$ line (d). The Raman bands that appear from the calcite (e) and dolomite (f) impurities are marked with arrows

The other weak bands found around 460, 370 and $320 \mathrm{~cm}^{-1}$ can not be unequivocally assigned because the bands originating from $\mathrm{M}-\mathrm{O}$ translations (the octahedral sites occupied by $\mathrm{Mg}$ cations) were mixed with tetrahedron deformation motions. The exceptions are the peaks around 300, 280 and $170 \mathrm{~cm}^{-1}$ which obviously arise from carbonate (calcite and dolomite) impurities (see Fig. $14 \mathrm{e}$ and $\mathrm{f}$ ). The remaining bands at 116 and 104 $\mathrm{cm}^{-1}$ are tentatively attributed to $\mathrm{K}-\mathrm{O}$ vibrations (Table 5 in Ref. [109]).

\section{Biotite, $\mathrm{K}\left(\mathrm{Fe}^{2+}, \mathrm{Mg}\right)_{3} \mathrm{AlSi}_{3} \mathrm{O}_{10}(\mathrm{OH}, \mathrm{F})_{2}$}

Figure $15 \mathrm{a}$ and $\mathrm{b}$ depicts the infrared spectra of two collected biotite samples. Here, it should be pointed out that the sample found in Čanište locality was initially designated as vermiculite $\left[\left(\mathrm{Mg}, \mathrm{Fe}^{2+}, \mathrm{Al}\right)_{3}(\mathrm{Al}, \mathrm{Si})_{4} \mathrm{O}_{10}(\mathrm{OH})_{2} \cdot 4 \mathrm{H}_{2} \mathrm{O}\right]$ because of the marked morphological similarities with this mineral. The results obtained from the chemical analysis were found to be very close and served as a preliminary indication that the samples were biotite: wt $\%, \mathrm{~K}_{2} \mathrm{O}-10.04 ; \mathrm{Na}_{2} \mathrm{O}<0.01 ; \mathrm{MgO}-$ 10.03; $\mathrm{CaO}<0.01 ; \mathrm{FeO}-22.73 ; \mathrm{SiO}_{2}-37.77$; $\mathrm{TiO}_{2}-1.18 ; \mathrm{Al}_{2} \mathrm{O}_{3}-16.14$ (Pelagon sample, Table 1) and $\mathrm{wt} \%, \mathrm{~K}_{2} \mathrm{O}-8.99 ; \mathrm{Na}_{2} \mathrm{O}<0.01 ; \mathrm{MgO}-$ 10.49; $\mathrm{CaO}<0.01 ; \mathrm{FeO}-19.89 ; \mathrm{SiO}_{2}-36.23$; 
$\mathrm{TiO}_{2}-1.35 ; \mathrm{Al}_{2} \mathrm{O}_{3}-13.45$ (Čanište sample). Moreover, the obtained IR spectrum using Nujol suspension mull (Fig. 15c) clearly demonstrated the presence of very weak bands from surfaceadsorbed water around $3400 \mathrm{~cm}^{-1}$ (also registered in the IR spectra recorded using $\mathrm{KBr}$ pellets). The band assignments and comparison with literature IR data are listed in Table 6 of Ref. [109]. The bands registered at $3556 \mathrm{~cm}^{-1}$ in the spectrum of the sample from Čanište and two bands in the spectrum of the sample from Pelagon $(3675,3555$ $\mathrm{cm}^{-1}$ ) are evidence for the presence of $\mathrm{OH}$ groups (Table 6 in Ref. [109]).

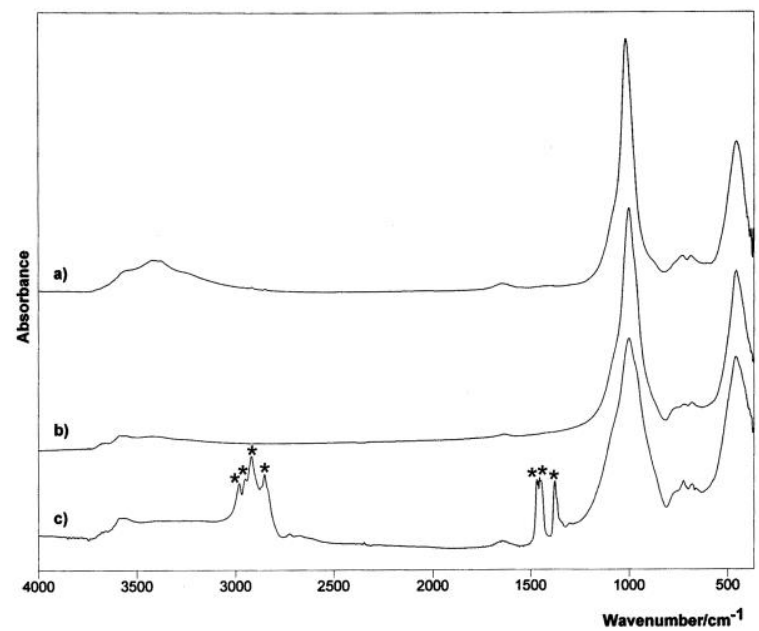

Fig. 15. FT IR spectra of biotite from Čanište (a) and Pelagon (b) obtained using KBr pellets. FT IR spectrum of biotite from Čanište (c) recorded in Nujol mulls. The Nujol bands are denoted by asterisks

The most intense band in the spectra of biotite was observed around $1010 \mathrm{~cm}^{-1}$, in very good agreement with the corresponding literature band [97, 98] (Table 6 in Ref. [109]). Although it has not been previously assigned, its appearance could undoubtedly be related to $v(\mathrm{Si}-\mathrm{O}-\mathrm{Si})$ vibrations. In general, the bands around 720, 680 and $460 \mathrm{~cm}^{-1}$ were observed at frequencies close to those found in the literature $[97,98]$. Due to the lack of band assignments in the literature, interpretation of the biotite (Table 6 in Ref. [109]) spectra was based on the discussion concerning previously studied sheet silicate minerals.

The identification of both biotite samples was continued by studying their Raman spectra obtained with $532 \mathrm{~nm}$ excitation (Fig. 16) since the spectra excited by 514.5 and $1064 \mathrm{~nm}$ lasers were of very poor quality. Here, it should be pointed out that the Raman spectrum of biotite was compared with the corresponding very low quality spectra found in internet databases [107, 108] (not found in the literature). Assignment of the Raman bands was undertaken in line with the discussion for the Raman spectra of the mica minerals. The highestfrequency peak around $1100 \mathrm{~cm}^{-1}$ present in both biotite spectra as well as in the internet spectrum [107], appears as a result of $v(\mathrm{Si}-\mathrm{O}-\mathrm{Si})$ mode. The most intense bands in the $700-550 \mathrm{~cm}^{-1}$ spectral region are attributed to $\mathrm{Si}-\mathrm{O}-\mathrm{Si}$ bending, whereas the bands originating from translational $\mathrm{M}-\mathrm{O}(\mathrm{M}=$ $\mathrm{Mg}, \mathrm{Fe}$ ) modes probably give rise to the maxima between 360 and $150 \mathrm{~cm}^{-1}$ (Table 7 in Ref. [109]). The remaining peaks most likely arise from $\mathrm{K}-\mathrm{O}$ translations.

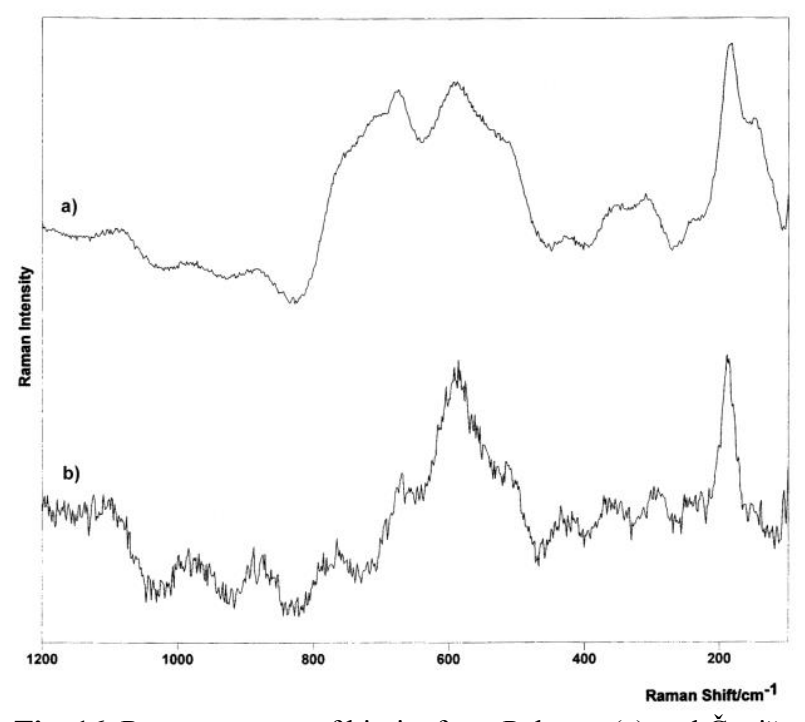

Fig. 16. Raman spectra of biotite from Pelagon (a) and Čanište (b) obtained using $532 \mathrm{~nm}$ excitation

It is worth mentioning that the IR spectra of phlogopite and biotite were very similar to each other. The exception is the appearance of the weak band at $813 \mathrm{~cm}^{-1}$ in the spectrum of phlogopite which was absent in the biotite spectrum.

\section{Sheridanite, $(\mathrm{Mg}, \mathrm{Al})_{6}(\mathrm{Si}, \mathrm{Al})_{4} \mathrm{O}_{10}(\mathrm{OH})_{8}$}

Similarly to the wrong preliminary contemplation of biotite as vermiculite, this mineral sample was initially morphologically characterized as kossmatite, $\mathrm{Ca}_{3} \mathrm{MgAl}_{2} \mathrm{AlSi}_{3} \mathrm{O}_{10}(\mathrm{OH}, \mathrm{F})_{9}$. However, the results of the $\mathrm{X}$-ray microprobe analysis of the sample from Sivec (wt\%, $\mathrm{CaO}-0.25 ; \mathrm{MgO}-$ 34.58; $\mathrm{SiO}_{2}-28.38 ; \mathrm{TiO}_{2}-0.02 ; \mathrm{Al}_{2} \mathrm{O}_{3}-23.31$; $\left.\mathrm{Na}_{2} \mathrm{O}-0.51 ; \mathrm{K}_{2} \mathrm{O}-0.04\right)$ compared to the chemical composition of kossmatite published by Erdmannsdöffer [113] $\left(\mathrm{SiO}_{2}-28.47 ; \mathrm{A}_{2} \mathrm{O}_{3}-22.84\right.$; $\mathrm{Fe}_{2} \mathrm{O}_{3}-0.26 ; \mathrm{MgO}-8.16 ; \mathrm{CaO}-27.10 ; \mathrm{Na}_{2} \mathrm{O}-$ $0.51 ; \mathrm{K}_{2} \mathrm{O}-0.07 ; \mathrm{F}-1.14 ; \mathrm{H}_{2} \mathrm{O}^{+}-11.69 ; \mathrm{H}_{2} \mathrm{O}^{-}-$ 0.82 ) showed a discrepancy with kossmatite. The 
finding resembles the result of Baric [114], who pointed out that kossmatite (found in dolomite marble from Sivec, Macedonia) did not represent a valid new mineral species and most likely was mistaken for margarite. Furthermore, the obtained data for the chemical composition of the studied sample were very close to those found for chlorite [114] (wt \%, $\mathrm{SiO}_{2}-28.21 ; \mathrm{Al}_{2} \mathrm{O}_{3}-24.64 ; \mathrm{FeO}-$ $0.16 ; \mathrm{MgO}-33.13 ; \mathrm{Na}_{2} \mathrm{O}-0.14 ; \mathrm{K}_{2} \mathrm{O}-0.19$; $\left.\mathrm{H}_{2} \mathrm{O}^{+}-12.97 ; \mathrm{H}_{2} \mathrm{O}^{-}-0.82\right)$. According to the Strunz classification system [115] several mineral species belong to the chlorite group and the studied sample, based on the chemical analysis mentioned before, is recognized as the sheridanite variety of $\mathrm{Mg}$-rich chlorite (clinochlore). Its infrared spectrum is presented in Figure 13c, whereas the band assignments (Table 8 in Ref. [109]) were based on the previously studied IR spectrum of clinochlore [66] (IR data for sheridanite are not found in the literature).

The infrared spectrum $\left(4000-400 \mathrm{~cm}^{-1}\right)$ was characterized by well-defined sharp bands, probably due to the high degree of structural order in this mineral. The appearance of three bands (at 3670, 3567 and $3431 \mathrm{~cm}^{-1}$ ) from $v(\mathrm{OH})$ stretching vibrations (Fig. 13c) is in agreement with the presence of three crystallographically different $\mathrm{OH}$ groups in the clinochlore structure. According to Prieto et al. [88] the first one (at $3670 \mathrm{~cm}^{-1}$ ) originates from $\mathrm{OH}$ groups not involved in hydrogen bonding, whereas the remaining two (at 3567 and 3431 $\mathrm{cm}^{-1}$ ) arise from $\mathrm{OH}$ groups participating in the formation of hydrogen bonds.

The band with medium intensity observed at $1449 \mathrm{~cm}^{-1}$ (Fig. 13c and e) undoubtedly originates from the presence of carbonate impurities since the chlorites in Sivec are associated with marbles [112]. The carbonate phase is also associated with the bands at 881 and $728 \mathrm{~cm}^{-1}$ due to the $v_{2}\left(\mathrm{CO}_{3}{ }^{2-}\right)$ and $v_{4}\left(\mathrm{CO}_{3}{ }^{2-}\right)$ modes, respectively. After treatment of the sample in $3 \mathrm{M} \mathrm{HCl}$, the carbonate phase was totally eliminated (Fig. 13d).

The band registered at $993 \mathrm{~cm}^{-1}$ is the most characteristic one in the IR spectrum of sheridanite and arises from $\mathrm{Si}-\mathrm{O}-\mathrm{Si}$ stretching vibrations (Table 8 in Ref. [109]). The bands found at 820 and $765 \mathrm{~cm}^{-1}$ most likely appear as a result of $v(\mathrm{Al}-\mathrm{O})$ vibrations, whereas the band at $677 \mathrm{~cm}^{-1}$ could be attributed to either symmetric $\mathrm{Si}-\mathrm{O}-\mathrm{Si}$ stretching mode or metal-hydroxyl libration. The bending $\mathrm{Si}-$ $\mathrm{O}-\mathrm{Si}$ modes give rise to the strong band at 444 $\mathrm{cm}^{-1}$ accompanied by the shoulder at $543 \mathrm{~cm}^{-1}$. The remaining strong bands observed at 465 and $382 \mathrm{~cm}^{-1}$ originate from $\mathrm{Mg}-\mathrm{OH}$ librations and carbonate contamination, respectively.
Figure 14d shows the Raman spectrum of sheridanite recorded with the $514 \mathrm{~nm}$ laser line. Similarly to the IR spectrum, the Raman data for sheridanite have not been reported in the literature. The highest-frequency peaks found at 1098 and 994 $\mathrm{cm}^{-1}$ are attributed to the $v_{1}\left(\mathrm{CO}_{3}\right)$ mode from the carbonate impurities (Fig. 14f) and antisymmetric $\mathrm{Si}-\mathrm{O}-\mathrm{Si}$ stretching modes, respectively (Table 8 in Ref. [109]). The symmetric $\mathrm{Si}-\mathrm{O}-\mathrm{Si}$ stretching mode is represented by the very strong peak at 683 $\mathrm{cm}^{-1}$, whereas the $\delta(\mathrm{Si}-\mathrm{O}-\mathrm{Si})$ mode gives rise to the maxima at 553, 436, 393 and $361 \mathrm{~cm}^{-1}$ (Fig. 14d). Four peaks were noticed in the $300-150 \mathrm{~cm}^{-1}$ spectral region (at 300, 276, 209 and $176 \mathrm{~cm}^{-1}$ ) and except for the first and fourth ones (carbonate impurities) (Fig. 14f), they could be assigned to metaloxygen translations (Table 8 in Ref. [109]).

\subsubsection{X-ray powder diffraction}

XRPD of the minerals was performed for identification purposes. Diagrams of the studied sheet silicates (chrysotile, antigorite, talc, clinochlore, cymrite, muscovite, phlogopite and biotite) are presented in Tables 4-11, respectively, where the most intense maxima and unit cell parameters derived from each mineral are compared with the crystallographic parameters taken from the literature data.

It should be pointed out that the calculated unit cell parameters $a$ and $c$ for muscovite, phlogopite and biotite (Tables 9-11) are arranged in the opposite order to corresponding parameters taken from the literature.

Table 4

The most intense maxima from the $X$-ray powder diagram of the studied chrysotile mineral used to calculate the unit cell parameters

\begin{tabular}{|c|c|c|c|c|c|}
\hline$h$ & $k$ & $l$ & $d_{\text {obs }}$ & $d_{\text {cal }}$ & $\boldsymbol{d}_{\text {diff }}$ \\
\hline 0 & 1 & 0 & 8.0332 & 7.989 & 0.0442 \\
\hline 0 & 0 & 2 & 4.6047 & 4.6039 & 0.0008 \\
\hline 0 & 2 & 0 & 3.9942 & 3.9945 & -0.0003 \\
\hline 1 & 1 & 2 & 3.2584 & 3.2585 & -0.0001 \\
\hline 0 & 0 & 4 & 2.3017 & 2.3019 & -0.0002 \\
\hline 0 & 1 & 4 & 2.2121 & 2.212 & 0.0001 \\
\hline \multicolumn{4}{|c|}{$\begin{array}{l}\text { Unit Cell Par.obs } \\
a=11.2835 \AA \\
b=3.5196 \AA \\
c=9.0387 \AA \\
\beta=93.82^{\circ} \\
V=358.164 \AA^{3}\end{array}$} & \multicolumn{2}{|c|}{$\begin{array}{l}\text { Unit Cell Par. [116] } \\
a=5.3 \AA \\
b=9.19 \AA \\
c=14.63 \AA \\
\beta=93^{\circ} \\
V=708.15 \AA^{3} \\
Z=4 \\
\text { Monoclinic }(A 2 / m)\end{array}$} \\
\hline
\end{tabular}


Table 5

The most intense maxima from the X-ray powder diagram of the studied antigorite mineral used to calculate the unit cell parameters

\begin{tabular}{|c|c|c|c|c|c|}
\hline$h$ & $k$ & $l$ & $d_{\text {obs }}$ & $d_{\text {cal }}$ & $d_{\text {diff }}$ \\
\hline 0 & 0 & 1 & 7.2663 & 7.2685 & -0.0022 \\
\hline 6 & 0 & 0 & 7.2132 & 7.2479 & -0.0347 \\
\hline-2 & 0 & 1 & 6.9754 & 6.9806 & -0.0052 \\
\hline 2 & 0 & 1 & 6.8098 & 6.8096 & 0.0002 \\
\hline-5 & 1 & 0 & 6.3300 & 6.3179 & 0.0121 \\
\hline-7 & 1 & 0 & 5.1582 & 5.1473 & 0.0109 \\
\hline 5 & 1 & 1 & 4.6878 & 4.6991 & -0.0113 \\
\hline 0 & 2 & 0 & 4.6059 & 4.5964 & 0.0095 \\
\hline-9 & 1 & 0 & 4.2867 & 4.2771 & 0.0096 \\
\hline 7 & 1 & 1 & 4.1405 & 4.1345 & 0.0060 \\
\hline 0 & 2 & 1 & 3.8900 & 3.8848 & 0.0052 \\
\hline-6 & 2 & 0 & 3.8817 & 3.8817 & 0.0000 \\
\hline-6 & 2 & 0 & 3.8783 & 3.8817 & -0.0034 \\
\hline-6 & 2 & 0 & 3.8667 & 3.8817 & -0.0150 \\
\hline 0 & 0 & 2 & 3.6347 & 3.6342 & 0.0005 \\
\hline \multicolumn{4}{|c|}{$\begin{array}{l}\text { Unit Cell Par. }{ }^{\text {obs }} \\
a=43.4910 \AA \\
b=9.1858 \AA \\
c=7.2691 \AA \\
\beta=92.36^{\circ} \\
V=2901.531 \AA^{3}\end{array}$} & \multicolumn{2}{|c|}{$\begin{array}{l}\text { Unit Cell Par. [117] } \\
a=43.53 \AA \\
b=9.259 \AA \\
c=7.263 \AA \\
\beta=91.633^{\circ} \\
V=2926.12 \AA^{3} \\
\underline{Z}=16 \\
\text { Monoclinic }(\mathrm{Cm})\end{array}$} \\
\hline
\end{tabular}

Table 6

The most intense maxima from the X-ray powder diagram of the studied talc mineral used to calculate the unit cell parameters

\begin{tabular}{|c|c|c|c|c|c|}
\hline$h$ & $k$ & $l$ & $d_{\text {obs }}$ & $\boldsymbol{d}_{\mathrm{cal}}$ & $\boldsymbol{d}_{\text {diff }}$ \\
\hline 0 & 2 & 0 & 9.3585 & 9.3613 & -0.0028 \\
\hline 0 & 4 & 0 & 4.6780 & 4.6806 & -0.0026 \\
\hline 2 & 0 & 0 & 4.4394 & 4.4382 & 0.0012 \\
\hline 1 & 1 & 1 & 4.0934 & 4.0937 & -0.0003 \\
\hline-2 & 2 & 0 & 4.0113 & 4.0103 & 0.0010 \\
\hline 1 & 3 & 1 & 3.4822 & 3.4817 & 0.0005 \\
\hline-2 & 2 & 1 & 3.4796 & 3.4796 & 0.0000 \\
\hline-2 & 4 & 0 & 3.2203 & 3.2206 & -0.0003 \\
\hline 0 & 6 & 0 & 3.1242 & 3.1204 & 0.0038 \\
\hline 0 & 6 & 0 & 3.1189 & 3.1204 & -0.0015 \\
\hline 1 & 5 & 1 & 2.7934 & 2.7936 & -0.0002 \\
\hline-2 & 6 & 0 & 2.5516 & 2.5527 & -0.0011 \\
\hline \multicolumn{4}{|c|}{$\begin{array}{l}\text { Unit Cell Par. }^{\text {obs }} \\
a=9.0242 \AA \\
b=18.7083 \AA \\
c=5.3417 \AA \\
\beta=100.62^{\circ} \\
V=886.373 \AA^{3}\end{array}$} & \multicolumn{2}{|c|}{$\begin{array}{l}\text { Unit Cell Par. [118] } \\
a=5.27 \AA \\
b=9.12 \AA \\
c=18.85 \AA \\
\beta=100.016^{\circ} \\
V=892.17 \AA^{3} \\
Z=4 \\
\text { Monoclinic }(C 2 / c)\end{array}$} \\
\hline
\end{tabular}

Table 7

The most intense maxima from the X-ray powder diagram of the studied clinochlore mineral used to calculate the unit cell parameters

\begin{tabular}{|c|c|c|c|c|c|}
\hline $\boldsymbol{h}$ & $k$ & $l$ & $d_{\text {obs }}$ & $d_{\text {cal }}$ & $d_{\text {diff }}$ \\
\hline 2 & 0 & 0 & 7.1179 & 7.1246 & -0.0067 \\
\hline 0 & 2 & 0 & 4.5952 & 4.5792 & 0.0160 \\
\hline 0 & 2 & 0 & 4.5671 & 4.5792 & -0.0121 \\
\hline-1 & 1 & 1 & 4.5006 & 4.4933 & 0.0073 \\
\hline-3 & 1 & 0 & 4.2113 & 4.2164 & -0.0051 \\
\hline-2 & 2 & 0 & 3.8592 & 3.8521 & 0.0071 \\
\hline 4 & 0 & 0 & 3.5568 & 3.5623 & -0.0055 \\
\hline-3 & 1 & 1 & 3.4963 & 3.4944 & 0.0019 \\
\hline 3 & 1 & 1 & 3.1162 & 3.1159 & 0.0003 \\
\hline-1 & 3 & 0 & 2.9761 & 2.9850 & -0.0091 \\
\hline-2 & 0 & 2 & 2.5818 & 2.5783 & 0.0035 \\
\hline-3 & 3 & 0 & 2.5725 & 2.5681 & 0.0044 \\
\hline-1 & 1 & 2 & 2.5366 & 2.5432 & -0.0066 \\
\hline 1 & 1 & 2 & 2.4419 & 2.4348 & 0.0071 \\
\hline 4 & 2 & 1 & 2.3796 & 2.3785 & 0.0011 \\
\hline \multicolumn{4}{|c|}{$\begin{array}{l}\text { Unit Cell Par.obs } \\
a=14.3636 \AA \\
b=9.1513 \AA \\
c=5.2981 \AA \\
\beta=97.57^{\circ} \\
V=690.338 \AA^{3}\end{array}$} & \multicolumn{2}{|c|}{$\begin{array}{l}\text { Unit Cell Par. [119] } \\
\begin{array}{l}a=5.305 \AA \\
b=9.180 \AA \\
c=14.339 \AA \\
\beta=97.57^{\circ} \\
V=692.2 \AA^{3} \\
Z=2 \\
\text { Monoclinic }(C 2 / m)\end{array}\end{array}$} \\
\hline
\end{tabular}

Table 8

The most intense maxima from the $X$-ray powder diagram of the studied cymrite mineral used to calculate the unit cell parameters

\begin{tabular}{|c|c|c|c|c|c|}
\hline$h$ & $k$ & $l$ & $d_{\text {obs }}$ & $d_{\text {cal }}$ & $\boldsymbol{d}_{\text {diff }}$ \\
\hline-4 & 0 & 1 & 4.6273 & 4.6275 & -0.0002 \\
\hline 4 & 1 & 1 & 3.9613 & 3.9622 & -0.0009 \\
\hline 0 & 2 & 0 & 3.8442 & 3.8451 & -0.0009 \\
\hline-9 & 1 & 1 & 2.9570 & 2.9568 & 0.0002 \\
\hline 7 & 2 & 1 & 2.6702 & 2.6701 & 0.0001 \\
\hline 8 & 2 & 1 & 2.5647 & 2.5649 & -0.0002 \\
\hline 5 & 0 & 2 & 2.5266 & 2.5271 & -0.0005 \\
\hline 8 & 0 & 2 & 2.3117 & 2.3116 & 0.0001 \\
\hline-4 & 3 & 1 & 2.2426 & 2.2423 & 0.0003 \\
\hline 8 & 1 & 2 & 2.2142 & 2.2137 & 0.0005 \\
\hline 2 & 2 & 2 & 2.1941 & 2.1940 & 0.0001 \\
\hline-8 & 2 & 2 & 1.9819 & 1.9825 & -0.0006 \\
\hline-18 & 1 & 0 & 1.9240 & 1.9236 & 0.0004 \\
\hline 2 & 3 & 2 & 1.8497 & 1.8497 & 0.0000 \\
\hline 19 & 0 & 1 & 1.7767 & 1.7769 & -0.0002 \\
\hline-5 & 1 & 3 & 1.7042 & 1.7040 & 0.0002 \\
\hline \multicolumn{4}{|c|}{$\begin{array}{l}\text { Unit Cell Par.obs } \\
a=35.7351 \AA \\
b=7.6842 \AA \\
c=5.4006 \AA \\
\beta=90.06^{\circ} \\
V=1482.980 \AA^{3}\end{array}$} & \multicolumn{2}{|c|}{$\begin{array}{l}\text { Unit Cell Par. [120] } \\
a=5.33 \AA \\
b=36.6 \AA \\
c=7.67 \AA \\
\beta=90^{\circ} \\
V=1496.25 \AA^{3} \\
Z=8 \\
\text { Monoclinic }(P 21)\end{array}$} \\
\hline
\end{tabular}


Table 9

The most intense maxima from the X-ray powder diagram of the studied muscovite mineral used to calculate the unit cell parameters

\begin{tabular}{|c|c|c|c|c|c|}
\hline$h$ & $k$ & $l$ & $d_{\text {obs }}$ & $d_{\text {cal }}$ & $d_{\text {diff }}$ \\
\hline 2 & 0 & 0 & 9.9457 & 9.9436 & 0.0021 \\
\hline 4 & 0 & 0 & 4.9729 & 4.9718 & 0.0011 \\
\hline 0 & 2 & 0 & 4.5268 & 4.5340 & -0.0072 \\
\hline-1 & 1 & 1 & 4.5040 & 4.4857 & 0.0183 \\
\hline-1 & 1 & 1 & 4.4815 & 4.4857 & -0.0042 \\
\hline 2 & 0 & 1 & 4.4197 & 4.4270 & -0.0073 \\
\hline 1 & 1 & 1 & 4.3156 & 4.3180 & -0.0024 \\
\hline-2 & 2 & 0 & 4.1216 & 4.1254 & -0.0038 \\
\hline-3 & 1 & 1 & 3.8900 & 3.8927 & -0.0027 \\
\hline 3 & 1 & 1 & 3.5843 & 3.5853 & -0.0010 \\
\hline 6 & 0 & 0 & 3.3161 & 3.3145 & 0.0016 \\
\hline-5 & 1 & 1 & 3.1210 & 3.1233 & -0.0023 \\
\hline-1 & 3 & 0 & 2.9902 & 2.9883 & 0.0019 \\
\hline 5 & 1 & 1 & 2.8621 & 2.8608 & 0.0013 \\
\hline-1 & 3 & 1 & 2.6091 & 2.6083 & 0.0008 \\
\hline \multicolumn{4}{|c|}{$\begin{array}{l}\text { Unit Cell Par. }{ }^{\text {obs }} \\
a=19.9756 \AA \\
b=9.0611 \AA \\
c=5.2235 \AA \\
\beta=95.84^{\circ} \\
V=940.555 \AA^{3}\end{array}$} & \multicolumn{2}{|c|}{$\begin{array}{l}\text { Unit Cell Par. [121] } \\
a=5.201 \AA \\
b=9.022 \AA \\
c=20.043 \AA \\
\beta=95.78^{\circ} \\
V=935.8 \AA^{3} \\
Z=4 \\
\text { Monoclinic }(C 2 / c)\end{array}$} \\
\hline
\end{tabular}

Table 10

The most intense maxima from the X-ray powder diagram of the studied phlogopite mineral used to calculate the unit cell parameters

\begin{tabular}{|c|c|c|c|c|c|}
\hline$h$ & $k$ & $l$ & $d_{\text {obs }}$ & $d_{\text {cal }}$ & $d_{\text {diff }}$ \\
\hline 2 & 0 & 0 & 9.9916 & 9.9796 & 0.0120 \\
\hline 4 & 0 & 0 & 4.9995 & 4.9898 & 0.0097 \\
\hline-1 & 1 & 1 & 4.5847 & 4.5822 & 0.0025 \\
\hline 0 & 2 & 0 & 4.5382 & 4.5313 & 0.0069 \\
\hline 1 & 1 & 1 & 4.2867 & 4.2890 & -0.0023 \\
\hline-5 & 1 & 0 & 3.6464 & 3.6532 & -0.0068 \\
\hline 3 & 1 & 1 & 3.5119 & 3.5098 & 0.0021 \\
\hline 4 & 0 & 1 & 3.3362 & 3.3345 & 0.0017 \\
\hline-5 & 1 & 1 & 3.2549 & 3.2546 & 0.0003 \\
\hline 2 & 2 & 1 & 3.1307 & 3.1344 & -0.0037 \\
\hline \multicolumn{4}{|c|}{$\begin{array}{l}\text { Unit Cell Par.obs } \\
a=20.2614 \AA \\
b=9.0557 \AA \\
c=5.3275 \AA \\
\beta=100.16^{\circ} \\
V=962.183 \AA^{3}\end{array}$} & \multicolumn{2}{|c|}{$\begin{array}{l}\text { Unit Cell Par. [122] } \\
a=5.33 \AA \\
b=9.24 \AA \\
c=20.07 \AA \\
\beta=95.125^{\circ} \\
V=984.48 \AA^{3} \\
Z=4 \\
\text { Monoclinic }(C 2 / m)\end{array}$} \\
\hline
\end{tabular}

Table 11

The most intense maxima from the X-ray powder diagram of the studied biotite mineral used to calculate the unit cell parameters

\begin{tabular}{|c|c|c|c|c|c|}
\hline $\bar{h}$ & k & $l$ & $d_{\text {obs }}$ & $d_{\text {cal }}$ & $\overline{d_{\text {diff }}}$ \\
\hline 2 & 0 & 0 & 5.0353 & 5.0356 & -0.0003 \\
\hline 0 & 2 & 0 & 4.6328 & 4.6314 & 0.0014 \\
\hline-1 & 1 & 1 & 4.4326 & 4.4357 & -0.0031 \\
\hline 1 & 1 & 1 & 3.9421 & 3.9472 & -0.0051 \\
\hline-2 & 2 & 0 & 3.4093 & 3.4088 & 0.0005 \\
\hline 2 & 0 & 1 & 3.3583 & 3.3561 & 0.0022 \\
\hline-3 & 1 & 0 & 3.1518 & 3.1562 & -0.0044 \\
\hline-3 & 1 & 1 & 2.9327 & 2.9318 & 0.0009 \\
\hline 2 & 2 & 1 & 2.7191 & 2.7176 & 0.0015 \\
\hline-1 & 3 & 1 & 2.6344 & 2.6346 & -0.0002 \\
\hline-2 & 0 & 2 & 2.5266 & 2.5264 & 0.0002 \\
\hline 4 & 0 & 0 & 2.5183 & 2.5178 & 0.0005 \\
\hline-4 & 0 & 1 & 2.4474 & 2.4469 & 0.0005 \\
\hline \multicolumn{4}{|c|}{$\begin{array}{l}\text { Unit Cell Par. }{ }^{\text {obs }} \\
a=10.2255 \AA \\
b=9.2558 \AA \\
c=5.3520 \AA \\
\beta=100.21^{\circ} \\
V=498.510 \AA^{3}\end{array}$} & \multicolumn{2}{|c|}{$\begin{array}{l}\text { Unit Cell Par. [123] } \\
a=5.343 \AA \\
b=9.258 \AA \\
c=10.227 \AA \\
\beta=100.26^{\circ} \\
V=497.79 \AA^{3} \\
Z=2 \\
\text { Monoclinic }(C 2 / m)\end{array}$} \\
\hline
\end{tabular}

\subsection{Tectosilicates (frame silicates)}

Continuing our previous work concerning the spectral and structural study of silicate minerals originating from Macedonia [19, 22, 23, 66, 76, $109,124-126]$, the vibrational spectra of four tectosilicates were studied (albite, microcline, sanidine and stilbite). Although the feldspar samples exhibited marked similarities in their spectra, an attempt was made to correlate their spectral and structural characteristics.

Several studies have been undertaken to describe the infrared spectra of albite [127-130], microcline [127-131] and sanidine [129, 130, 124132]. On the other hand, the IR spectrum of the zeolite member stilbite is not discussed in detail [133-135] and the bands are not well resolved, probably due to instrument limitations. In addition, there is no detailed description of the stilbite Raman spectrum although some general assignments are given for the bands below $500 \mathrm{~cm}^{-1}[136,137]$. On the other hand, attention has been focused on the Raman spectral analysis of feldspars: albite [138-145], microcline [144, 146] and sanidine $[143,146]$. However, the results from this work give clearer insight into the vibrational spectral characteristics of this geologically important min- 
eral group particularly at lower wavenumbers. Furthermore, the difficulties connected with their identification and characterization and especially those related to the possibility of their contamination with other minerals are also discussed.

The study of these minerals has been undertaken for at least two reasons: (i) to undertake a systematic study of the tectosilicate minerals collected from Macedonia by vibrational spectroscopy and to correlate them with their structural data and (ii) since all minerals show structural similarities, it is important to find out whether vibrational spectroscopy and XRPD could be used to discriminate between the studied alkali feldspar minerals. Therefore, the aim of this work was to compile our vibrational data with the literature data and to present a summed analysis of the infrared and Raman spectra mainly based on their structural characteristics as well as to confirm their identity by XRPD. The details of the use of vibrational spectroscopy for identification of albite, microcline, sanidine and stilbite tectosilicate minerals from R. Macedonia are presented in Ref. [147].

\subsubsection{Vibrational spectra of alkali feldspars: albite, $\mathrm{NaAlSi}_{3} \mathrm{O}_{8}$, microcline, $\mathrm{KAlSi}_{3} \mathrm{O}_{8}$, and sanidine, $(\mathrm{K}, \mathrm{Na})(\mathrm{Si}, \mathrm{Al})_{4} \mathrm{O}_{8}$}

The infrared vibrational spectra of the alkali feldspars (albite, microcline and sanidine) (Fig. $17 \mathrm{a}-\mathrm{c})$ were, to some extent, similar. Their main characteristic is the existence of bands in four regions. The highest-frequency region, adopting the bands in the $1200-850 \mathrm{~cm}^{-1}$ region followed by the bands between 800 and $700 \mathrm{~cm}^{-1}$, could be used to discriminate between these minerals. On the other hand, the bands in the third region $\left(700-350 \mathrm{~cm}^{-1}\right)$ indicate that the samples are crystalline since they are not present in the corresponding glasses [130]. Spectral variations in terms of the number of bands, as well as variations in band intensities, were observed at the lowest wavenumbers (far-IR spectra, below $350 \mathrm{~cm}^{-1}$ ).

An increase of the $\mathrm{Al} / \mathrm{Si}$ disorder degree in alkali feldspars is manifested by a decrease of IR band intensities, frequency band shifting and an increase of their widths [148, 149]. Thus, the largest number of bands in the albite IR spectrum serves as an indication of the existence of the highest $\mathrm{Si} / \mathrm{Al}$ order in the structural tetrahedra sites compared to microcline and sanidine (Fig. 17a-c and Table 3 in Ref. [147]). Therefore, the strong absorption in microcline and sanidine spectra (single band) and in the albite spectrum (doublet) around $1150 \mathrm{~cm}^{-1}$ is predominantly associated to $\mathrm{Si}-\mathrm{O}-\mathrm{Si}$ bridging stretching vibrations [150].

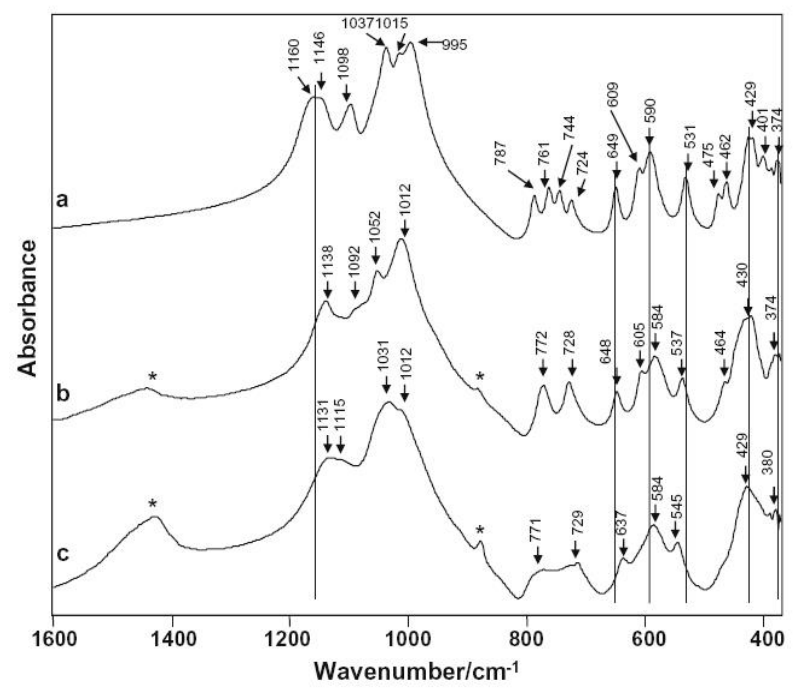

Fig. 17. IR spectra of alkali feldspars: (a) albite, (b) microcline and (c) sanidine. The bands marked with asterisks originate from calcite impurity. The wavenumber of the bands and the vertical lines are given to easily follow the discussion.

Despite shifting to lower wavenumbers going from ordered (albite, $1160 \mathrm{~cm}^{-1}$ ) to disordered mineral structure (sanidine, $1131 \mathrm{~cm}^{-1}$ ), its intensity and sharpness significantly decreased (Fig. 17ac). Similar shifting behavior was evident for the albite $1098 \mathrm{~cm}^{-1}$ medium band which appeared as a shoulder at $1092 \mathrm{~cm}^{-1}$ in microcline and was practically absent in the sanidine IR spectrum. The spectral differences continue in the $1060-995 \mathrm{~cm}^{-1}$ region as well, where the bands at $1037 \mathrm{~cm}^{-1}$ (albite), $1052 \mathrm{~cm}^{-1}$ (microcline) and $1031 \mathrm{~cm}^{-1}$ (sanidine) arise mainly from the second type of bridging, i.e. from $\mathrm{Si}-\mathrm{O}-\mathrm{Al}$ stretching [150]. It seems that the other bands in this region could not be closely related to the structural behavior of the minerals except for the fact that they are best resolved in the albite IR spectrum. According to Iiishi et al. [151] the bands in the highest IR region are attributed to tetrahedrally coordinated ion-oxygen stretching vibrations (Table 3 in Ref. [147]).

Four bands were registered in the IR spectrum of albite in the $800-700 \mathrm{~cm}^{-1}$ region, whereas only two bands were observed in the spectra of potassium feldspars (Table 3 in Ref. [147]). The increase of the structural order (going from sanidine to albite) involves much better sharpness and narrows the bands that originate from tetrahedraltetrahedral ion vibrations and from a combination of $\mathrm{Si}(\mathrm{Al})-\mathrm{Al}-\mathrm{O}$ and $\mathrm{Si}-\mathrm{O}-\mathrm{Si}$ vibrational modes [151]. However, according to Handke and Mozgawa [150] these bands are complex with contributions from high-frequency silica framework (pseudo-lattice) vibrations. Thus, the bands around 770 $\mathrm{cm}^{-1}$ are due to $\mathrm{Si}_{2} \mathrm{O}$ unit bending vibrations because these minerals (whose structure network 
consists of linked $\mathrm{AlO}_{4}$ and $\mathrm{SiO}_{4}$ tetrahedra with a $1: 3$ ratio) contain $\mathrm{Si}-\mathrm{O}-\mathrm{Si}$ bridges.

Although the bands in the $700-500 \mathrm{~cm}^{-1}$ IR region were assigned as $\mathrm{O}-\mathrm{Si}-\mathrm{O}$ and $\mathrm{O}-\mathrm{Al}-\mathrm{O}$ bending vibrations [151, 152], later it was shown that the bands in this region could be attributed to pseudo-lattice or tetrahedral (network) ring vibrations (responsible for the $\mathrm{Al} / \mathrm{Si}$ disorder) [150]. Although mentioned that the band around $650 \mathrm{~cm}^{-1}$ did not exhibit significant changes in peak position with the chemical composition [153], according to the studied spectra it was shifted to lower wavenumbers with increasing $\mathrm{Al} / \mathrm{Si}$ disorder (Fig. 17a-c and Table 3 in Ref. [147]). The frequency of the band near $540 \mathrm{~cm}^{-1}$, despite being affected by the composition [153], showed the opposite trend, being positioned at a higher wavenumber in the spectrum of the studied mineral with the most expressed structural disorder (Fig. 17 and Table 3 in Ref. [147]). Taking into account that this band is compositionally dependent, it might be coupled with $\mathrm{M}-\mathrm{O}(\mathrm{M}=\mathrm{K}$ and $\mathrm{Na})$ stretching having mixed character. On the other hand, although according to Zhang et al. [153] the band around 590 $\mathrm{cm}^{-1}$ is only slightly affected by the composition, its remarkable shift to lower frequencies going from the albite to sanidine spectra could be correlated with structural disorder. Another important spectral feature is the observed decrease of intensity of the mentioned bands going from albite to sanidine (Fig. 17a-c and Table 3 in Ref. [147]). In addition, bending $\mathrm{O}-\mathrm{Si}-\mathrm{O}$ and $\mathrm{O}-\mathrm{Al}-\mathrm{O}$ motions that involve bridging oxygens occurred in the 500 $330 \mathrm{~cm}^{-1}$ region which accords with assignment of the strongest peak around $430 \mathrm{~cm}^{-1}$ whose wavenumber and intensity were practically constant in all alkali feldspar IR spectra.

In the IR spectral region below $350 \mathrm{~cm}^{-1}$ (Fig. 18 a, c and e), the effect of the chemical composition on the band profiles can be seen. Very good correlation could be drawn taking into account the $\mathrm{M}-\mathrm{O}$ vibrations $(\mathrm{M}=\mathrm{Na}$ and/or $\mathrm{K})$ (Table 3 in Ref. [147]). Namely, the band at $184 \mathrm{~cm}^{-1}$ as well as its lower- and higher-frequency neighbors (199 and $\left.164 \mathrm{~cm}^{-1}\right)$ solely appeared in the albite $\left(\mathrm{NaAlSi}_{3} \mathrm{O}_{8}\right)$ spectrum and is attributed to $v(\mathrm{Na}-\mathrm{O})$ vibrations (Fig. 18a). On the other hand, microcline, $\mathrm{KAlSi}_{3} \mathrm{O}_{8}$, and sanidine, $(\mathrm{K}, \mathrm{Na})(\mathrm{Al}, \mathrm{Si})_{4} \mathrm{O}_{8}$, in which the presence of $\mathrm{K}(11.30 \mathrm{wt} \%)$ is considerably higher compared to $\mathrm{Na}(2.40 \mathrm{wt} \%)$ (Table 1), exhibited bands from $v(\mathrm{~K}-\mathrm{O})$ vibrations in their spectra. Their positioning at lower wavenumbers (115 and $107 \mathrm{~cm}^{-1}$, Table 3 in Ref. [147]) is in accordance with the heavier $\mathrm{K}$ atom (compared to $\mathrm{Na}$ ). On the other hand, the common band around $220 \mathrm{~cm}^{-1}$ as well as the $160-130 \mathrm{~cm}^{-1}$ bands could be tentatively attributed to lattice vibrations.

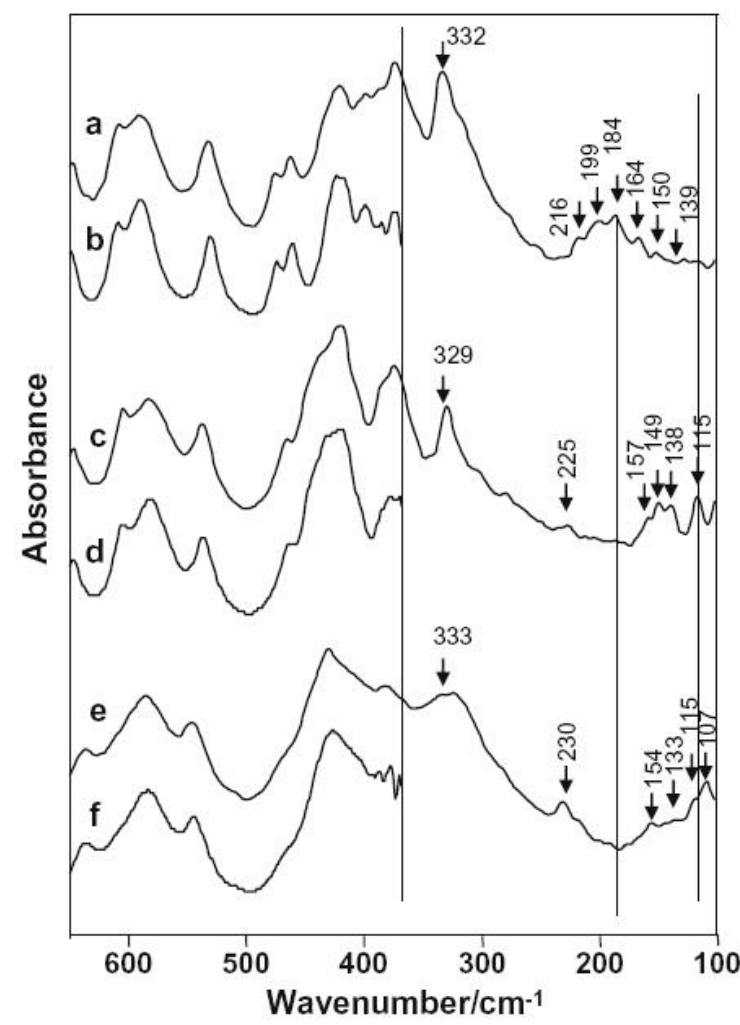

Fig. 18. Far-IR spectra of alkali feldspars $\left(650-100 \mathrm{~cm}^{-1}\right)$ : (a) albite, (c) microcline and (e) sanidine. The $650-370 \mathrm{~cm}^{-1}$ region of the mid-IR spectra: (b) albite, (d) microcline and

(f) sanidine are given to confirm the reproducibility. The wavenumber of the bands below $370 \mathrm{~cm}^{-1}$ as well as the vertical lines are given to easily follow the discussion.

Obviously, the IR bands at 1432 and 876 $\mathrm{cm}^{-1}$ are due to calcite impurities present in the microcline and sanidine samples and do not appear from fundamental vibrations. The weakest band from the $v_{4}\left(\mathrm{CO}_{3}\right)$ mode [154] is also evident in the sanidine spectrum $\left(713 \mathrm{~cm}^{-1}\right.$, Fig. $\left.17 \mathrm{c}\right)$, being an indicator for the higher content of calcite impurity in the sanidine sample.

In Figure 19a-c are presented the Raman spectra of the studied alkali feldspars. Two striking differences are evident in comparison with the IR spectral view - the bands do not fit into wellseparated regions and the most intense peaks appeared below $600 \mathrm{~cm}^{-1}$. Another general characteristic is that the spectra of the more ordered feldspars (albite and microcline) were richer in bands (Table 4 in Ref. [147]). Apparently, in the $\mathrm{Si}-$ $\mathrm{O}(\mathrm{Si})$ and $\mathrm{Si}-\mathrm{O}(\mathrm{Al})$ stretching region (1150-975 $\mathrm{cm}^{-1}$ ) where the band around $1100 \mathrm{~cm}^{-1}$ (albite and microcline), related to vibration involving nonbridging oxygen, is missing in sanidine. The bands around 815 and $760 \mathrm{~cm}^{-1}$ according to Sharma et al. [155] are prescribed to inter-tetrahedral modes (or $\mathrm{Si}_{2} \mathrm{O}$ unit bending vibrations [150]) (Table 4 in Ref. [147] and Fig. 19a-c). 


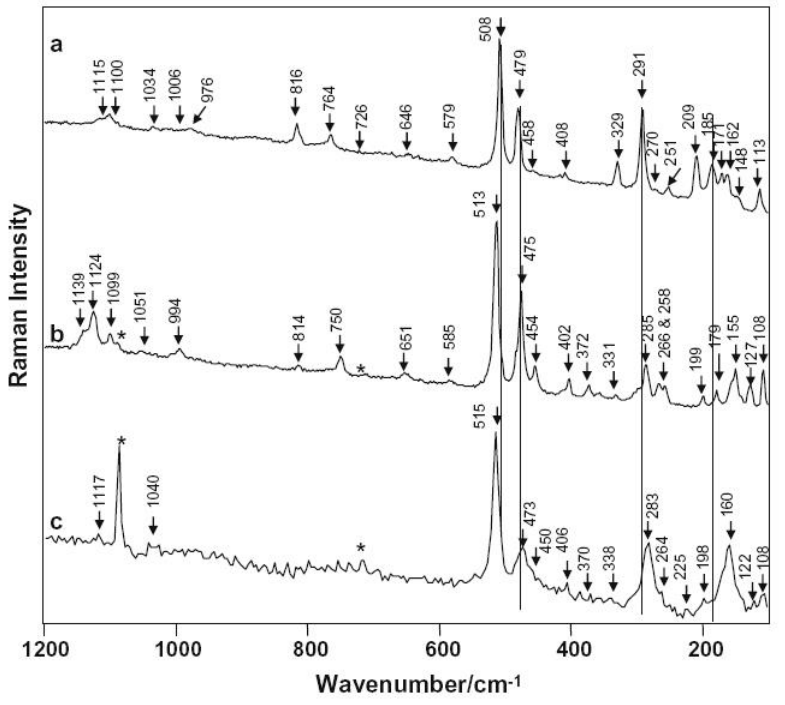

Fig. 19. Micro-Raman spectra of alkali feldspars: (a) albite, (b) microcline and (c) sanidine. The bands marked with asterisks originate from calcite impurity. The wavenumber of the bands as well as the vertical lines are given to easily follow the discussion.

The Raman spectral range between 700 and $500 \mathrm{~cm}^{-1}$ is characterized by the appearance of bands from tetrahedral ring vibrations [150] that are responsible for $\mathrm{Al} / \mathrm{Si}$ order/disorder effects. The very weak band at $580 \mathrm{~cm}^{-1}$ is the discriminating feature between the glasses and crystals, having strong intensity in amorphous materials [145]. The best indicators for $\mathrm{Al} / \mathrm{Si}$ disorder effects are also the bending $\mathrm{O}-\mathrm{Si}(\mathrm{Al})-\mathrm{O}$ vibrations that produced the bands between 540 and $300 \mathrm{~cm}^{-1}$. Namely, the frequency of the band around $510 \mathrm{~cm}^{-1}$ increased whereas the intensity of the peak at $480 \mathrm{~cm}^{-1}$ decreased with the increase of structural disorder (Table 4 in Ref. [147] and Fig. 19a-c). The intensity diminishing the band around $330 \mathrm{~cm}^{-1}$ as well as the broadening of the band near $290 \mathrm{~cm}^{-1}$ (lattice vibration [156]), going from albite to sanidine (Fig. 19ac), fits into these considerations. In addition, the smaller number of bands in sanidine compared to microcline and albite is additional evidence for its poorly ordered structure (Table 4 in Ref. [147]).

At the lowest frequencies, lattice modes, sometimes affected by the presence of larger cations and corresponding $\mathrm{M}-\mathrm{O}$ translational modes $(\mathrm{M}=\mathrm{Na}, \mathrm{K})$, are expected. Thus, the bands at 209, 185 and $162 \mathrm{~cm}^{-1}$ in the albite spectrum could be related to $v(\mathrm{Na}-\mathrm{O})$ modes, whereas (similarly to the IR consideration) the band around $125 \mathrm{~cm}^{-1}$ in the spectra of microcline and sanidine arises from $v(\mathrm{~K}-\mathrm{O})$ vibrations. The remaining common bands for the alkali feldspars are connected to lattice modes (Table 4 in Ref. [147]).
Both strongest bands from the calcite arising as an impurity in the microcline were observed at 1086 and $714 \mathrm{~cm}^{-1}$, whereas their higher intensity in the sanidine spectrum serves as an indicator for much greater carbonate contamination of this specimen.

\subsubsection{Vibrational spectra of a zeolite-type mineral - stilbite, $\mathrm{Na}_{3} \mathrm{Ca}_{3} \mathrm{Al}_{8} \mathrm{Si}_{28} \mathrm{O}_{72} \cdot 30 \mathrm{H}_{2} \mathrm{O}$}

Compared to the alkali feldspars, IR bands in the zeolite-type mineral stilbite were very wide, not well resolved and less informative. Strong absorption with maxima or shoulders around 3610 , 3420 and $3255 \mathrm{~cm}^{-1}$ were registered in the $\mathrm{H}_{2} \mathrm{O}$ stretching region $\left(3700-3100 \mathrm{~cm}^{-1}\right)$, whereas the corresponding bending mode was observed at 1649 $\mathrm{cm}^{-1}$ (Fig. 20a and Table 5 in Ref. [147]).

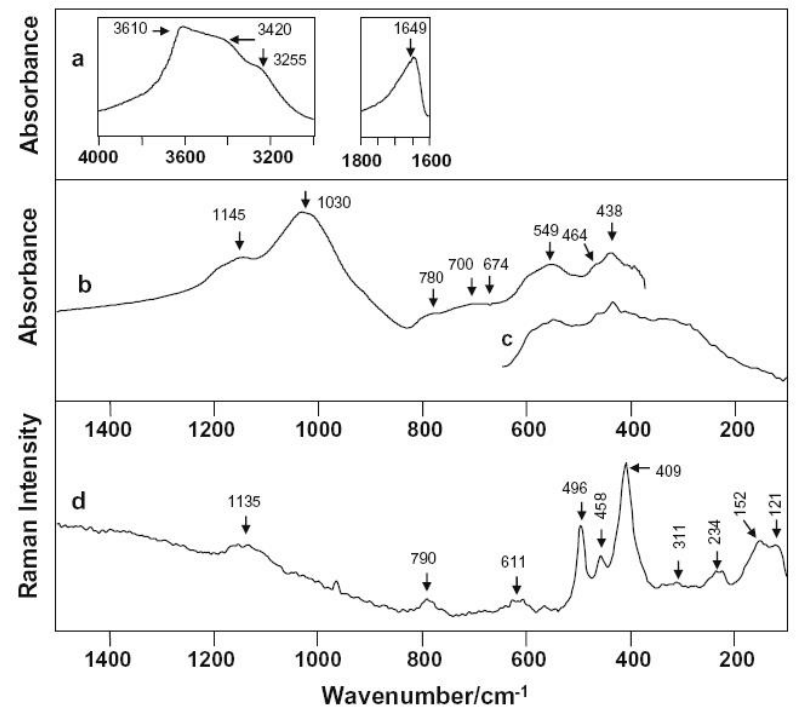

Fig. 20. IR spectrum of stilbite typical for the appearance of bands due to stretching and bending water vibrations (a). The region of fundamental $\mathrm{Si}(\mathrm{Al}) \mathrm{O}_{4}$ vibrations (b). The far-IR spectrum is also given (c). The FT-Raman spectrum is given for comparison (d). The wavenumbers for the bands are given to easily follow the discussion.

The $\mathrm{Si}-\mathrm{O}$ and $\mathrm{Al}-\mathrm{O}$ antisymmetric stretching modes of internal $\mathrm{MO}_{4}$ tetrahedra and $\mathrm{MO}_{4-}^{-}$ built external linkages give rise to the intense complex and wide bands around 1030 and $1145 \mathrm{~cm}^{-1}$, respectively (Fig. 20b and Table 5 in Ref. [147]). In addition, the weak bands (shoulders) from the mentioned symmetric stretching obviously appeared around 780 and $700 \mathrm{~cm}^{-1}$ in agreement with the assignment proposed for the heulandite mineral [157] that structurally fits in the same zeolite subgroup. Similarly, in the work of Kasture et al. [134] both peaks are assigned as $\mathrm{TO}_{4}$ bending vibrations $(\mathrm{T}=\mathrm{Si}$ or $\mathrm{Al})$ from the external linkages and internal tetrahedra. 
According to Prasad et al. [135], the bands at 546 and $442 \mathrm{~cm}^{-1}$ (549 and $438 \mathrm{~cm}^{-1}$ in our spectrum) are prescribed to symmetric $\mathrm{TO}_{4}$ stretching and bending, respectively. However, the band frequency around $550 \mathrm{~cm}^{-1}$ is very low for the symmetric $\mathrm{TO}_{4}$ stretching mode (half the wavenumber of the corresponding antisymmetric band). Moreover, taking into account assignment of the bands in the corresponding Raman spectrum they should appear from four-membered and fivemembered ring vibrations, respectively [137]. According to this author, the band around $670 \mathrm{~cm}^{-1}$ arises from the higher-membered ring vibrations (eight- and ten-membered rings) (Table 5 in Ref. [147] and Fig. 20b).

The spectrum of stilbite in the far-IR region (Fig. 20c) is rather complicated, especially below $350 \mathrm{~cm}^{-1}$ where precise band assignment is practically impossible to carry out. Additional difficulty involves determination of the band positions since the great complexity of the spectral view is probably introduced by the large number of $\mathrm{H}_{2} \mathrm{O}$ molecules in the mineral structure. However, there is no doubt that lattice and $\mathrm{M}-\mathrm{O}$ modes are expected to evolve in this region.

The Raman active antisymmetric $\mathrm{MO}_{4}$ vibrations from the internal tetrahedra appeared as a broad and weak band around $1135 \mathrm{~cm}^{-1}$ whereas the symmetric $(\mathrm{Si}(\mathrm{Al})-\mathrm{O})$ vibration from the external linkages evolved around $790 \mathrm{~cm}^{-1}$ (Table 5 in Ref. [147] and Fig. 20d). Mozgawa [137] presented the first tentative assignment for some of the bands in the Raman spectrum of stilbite, assigning the peaks in the $500-480 \mathrm{~cm}^{-1}$ region to the "breathing" vibrations of the four-membered rings and the bands in the $415-390 \mathrm{~cm}^{-1}$ region to the five-membered ring vibrations (496 and $409 \mathrm{~cm}^{-1}$ in our spectrum, Fig. 20d). On the other hand, Lodzinski et al. [136] assigned the stilbite Raman band at $458 \mathrm{~cm}^{-1}$ to translations and rotations. The proposed assignment by Lodzinski et al. [136] is rather questionable because according to the IR consideration presented above as well as the Raman assignments by Mozgawa [137], the band should arise from the breathing vibrations of the four-membered $\mathrm{TO}_{4}$ tetrahedra rings (Table 5 in Ref. [147]). As mentioned, the band at $496 \mathrm{~cm}^{-1}$ is related to the same type of breathing vibration (also known as ring pore opening).

Compared to the infrared pattern, the Raman spectral view below $350 \mathrm{~cm}^{-1}$ was better resolved. In line with the discussion of the $\mathrm{M}-\mathrm{O}$ vibrations in the alkali feldspars one might prescribe the band at $152 \mathrm{~cm}^{-1}$ to $v(\mathrm{Na}-\mathrm{O})$ vibrations whereas the remaining bands $\left(311,234\right.$ and $\left.121 \mathrm{~cm}^{-1}\right)$ could be related to lattice modes.

\subsubsection{X-ray powder diffraction}

Since the chemical composition of the studied minerals can vary substantially, it can be reflected in the view of their vibrational spectra. Therefore, the chemical composition of the samples was determined using an electron microprobe analyzer (Table 1). Furthermore, the X-ray powder diagrams of the minerals were recorded for identification purposes and the calculated unit cell parameters for each studied tectosilicate mineral are given in Tables 12-15.

Table 12

The most intense maxima from the X-ray powder diagram of the studied albite mineral used to calculate the unit cell parameters

\begin{tabular}{|c|c|c|c|c|c|}
\hline$h$ & $k$ & $l$ & $d_{\mathrm{obs}}$ & $d_{\text {cal }}$ & $d_{\text {diff }}$ \\
\hline-1 & 0 & 1 & 6.3891 & 6.3885 & 0.0006 \\
\hline 0 & -2 & 0 & 6.3754 & 6.3734 & 0.0020 \\
\hline-1 & 1 & 0 & 6.3391 & 6.3385 & 0.0006 \\
\hline-1 & -1 & 0 & 6.2987 & 6.2979 & 0.0008 \\
\hline 0 & -1 & 1 & 5.9099 & 5.9093 & 0.0006 \\
\hline 0 & 1 & 1 & 5.5842 & 5.5843 & -0.0001 \\
\hline 1 & 0 & 1 & 4.0257 & 4.0263 & -0.0006 \\
\hline-2 & -1 & 1 & 3.8534 & 3.8530 & 0.0004 \\
\hline-2 & 1 & 1 & 3.7760 & 3.7757 & 0.0003 \\
\hline 1 & -3 & 0 & 3.6806 & 3.6809 & -0.0003 \\
\hline 0 & -3 & 1 & 3.6656 & 3.6651 & 0.0005 \\
\hline-1 & -3 & 0 & 3.6567 & 3.6571 & -0.0004 \\
\hline-1 & -1 & 2 & 3.5051 & 3.5053 & -0.0002 \\
\hline 1 & -2 & 1 & 3.4809 & 3.4805 & 0.0004 \\
\hline-1 & 1 & 2 & 3.3721 & 3.3724 & -0.0003 \\
\hline 1 & 2 & 1 & 3.3325 & 3.3323 & 0.0002 \\
\hline 0 & 0 & 2 & 3.2147 & 3.2143 & 0.0004 \\
\hline-2 & 0 & 2 & 3.1944 & 3.1943 & 0.0001 \\
\hline 0 & -4 & 0 & 3.1865 & 3.1867 & -0.0002 \\
\hline 2 & -2 & 0 & 3.1688 & 3.1693 & -0.0005 \\
\hline-2 & -2 & 0 & 3.1491 & 3.1490 & 0.0001 \\
\hline-2 & -3 & 1 & 2.9640 & 2.9642 & -0.0002 \\
\hline 0 & -2 & 2 & 2.9544 & 2.9547 & -0.0003 \\
\hline-2 & -2 & 2 & 2.9308 & 2.9310 & -0.0002 \\
\hline 1 & -4 & 0 & 2.9270 & 2.9270 & 0.0000 \\
\hline $\begin{array}{l}\text { Un } \\
a= \\
b= \\
c= \\
\alpha= \\
\beta= \\
\gamma= \\
V=\end{array}$ & $\begin{array}{l}\text { Cell } \\
.074 \\
2.77 \\
.152 \\
4.27 \\
15.8 \\
8.53 \\
662.2\end{array}$ & $\begin{array}{l}\operatorname{ar}^{\text {.obs }} \\
\AA \\
8 \AA \\
\AA \\
0^{\circ} \\
1 \AA^{3}\end{array}$ & & \multicolumn{2}{|c|}{$\begin{array}{l}\text { Unit Cell Par.[158] } \\
a=8.135 \AA \\
b=12.784 \AA \\
c=7.1594 \AA \\
\alpha=94.271^{\circ} \\
\beta=116.594^{\circ} \\
\gamma=87.717^{\circ} \\
V=663.98 \AA^{3} \\
Z=4 \\
\text { Triclinic }(C \overline{1})\end{array}$} \\
\hline
\end{tabular}


As seen, the results are in good agreement with the corresponding literature data [158-161]. The most intense maxima and the unit cell parameters derived from the X-ray powder diagrams of the studied tectosilicates (albite, microcline, sanidine and stilbite) are presented in Tables $12-15$, respectively.

Table 13

The most intense maxima from the $X$-ray powder diagram of the studied microcline mineral used to calculate the unit cell parameters

\begin{tabular}{|c|c|c|c|c|c|}
\hline$h$ & $k$ & $l$ & $d_{\text {obs }}$ & $d_{\text {cal }}$ & $d_{\text {diff }}$ \\
\hline-1 & 1 & 0 & 6.7375 & 6.7372 & 0.0003 \\
\hline-1 & 0 & 1 & 6.4917 & 6.4924 & -0.0007 \\
\hline 0 & -2 & 0 & 6.4728 & 6.4766 & -0.0038 \\
\hline 0 & -1 & 1 & 5.9336 & 5.9342 & -0.0006 \\
\hline 0 & 1 & 1 & 5.8022 & 5.8012 & 0.0010 \\
\hline-1 & 2 & 1 & 4.5988 & 4.5975 & 0.0013 \\
\hline 1 & 0 & 1 & 4.2203 & 4.2190 & 0.0013 \\
\hline-2 & 1 & 1 & 3.9794 & 3.9805 & -0.0011 \\
\hline-2 & -1 & 1 & 3.9256 & 3.9242 & 0.0016 \\
\hline-2 & 0 & 0 & 3.8502 & 3.8511 & -0.0009 \\
\hline-1 & 3 & 0 & 3.8322 & 3.8309 & 0.0013 \\
\hline-1 & -3 & 0 & 3.7047 & 3.7049 & -0.0002 \\
\hline 0 & -3 & 1 & 3.6582 & 3.6573 & 0.0009 \\
\hline 1 & -2 & 1 & 3.6000 & 3.6006 & -0.0006 \\
\hline 0 & 3 & 1 & 3.5631 & 3.5644 & -0.0013 \\
\hline-1 & -1 & 2 & 3.4862 & 3.4876 & -0.0014 \\
\hline 1 & 2 & 1 & 3.4729 & 3.4730 & -0.0001 \\
\hline-1 & 1 & 2 & 3.4662 & 3.4653 & 0.0009 \\
\hline 2 & -2 & 0 & 3.3684 & 3.3686 & -0.0002 \\
\hline 0 & 0 & 2 & 3.2903 & 3.2901 & 0.0002 \\
\hline-2 & -2 & 0 & 3.2549 & 3.2546 & 0.0003 \\
\hline \multicolumn{4}{|c|}{ Unit Cell Par. ${ }^{\text {obs }}$} & \multicolumn{2}{|c|}{ Unit Cell Par.[159] } \\
\hline \multicolumn{4}{|c|}{$a=8.4472 \AA$} & \multicolumn{2}{|c|}{$a=8.5714 \AA$} \\
\hline \multicolumn{4}{|c|}{$b=12.9542 \AA$} & \multicolumn{2}{|c|}{$b=12.9645 \AA$} \\
\hline \multicolumn{4}{|c|}{$c=7.2139 \AA$} & \multicolumn{2}{|c|}{$c=7.2203 \AA$} \\
\hline \multicolumn{4}{|c|}{$\alpha=90.75^{\circ}$} & \multicolumn{2}{|c|}{$\alpha=90.74^{\circ}$} \\
\hline \multicolumn{4}{|c|}{$\beta=114.24^{\circ}$} & \multicolumn{2}{|c|}{$\beta=115.944^{\circ}$} \\
\hline \multicolumn{4}{|c|}{$\gamma=91.74^{\circ}$} & \multicolumn{2}{|c|}{$\gamma=87.783^{\circ}$} \\
\hline \multicolumn{4}{|c|}{$V=719.158 \AA^{3}$} & \multicolumn{2}{|c|}{$V=720.88 \AA^{3}$} \\
\hline & & & & \multicolumn{2}{|c|}{$Z=4$} \\
\hline
\end{tabular}

Table 14

The most intense maxima from the $X$-ray powder diagram of the studied sanidine mineral used to calculate the unit cell parameters

\begin{tabular}{|c|c|c|c|c|c|}
\hline $\boldsymbol{h}$ & $\boldsymbol{k}$ & $l$ & $d_{\text {obs }}$ & $d_{\text {cal }}$ & $d_{\text {diff }}$ \\
\hline-2 & 0 & 1 & 4.1756 & 4.1867 & -0.0111 \\
\hline 1 & 1 & 1 & 3.9274 & 3.9284 & -0.0010 \\
\hline-1 & 3 & 0 & 3.7736 & 3.7720 & 0.0016 \\
\hline-1 & 3 & 1 & 3.6157 & 3.6151 & 0.0006 \\
\hline-2 & 2 & 1 & 3.5256 & 3.5209 & 0.0047 \\
\hline-1 & 1 & 2 & 3.4612 & 3.4606 & 0.0006 \\
\hline-2 & 2 & 0 & 3.2947 & 3.2935 & 0.0012 \\
\hline 0 & 0 & 2 & 3.2226 & 3.2280 & -0.0054 \\
\hline 1 & 3 & 1 & 2.9868 & 2.9876 & -0.0008 \\
\hline-1 & 3 & 2 & 2.7664 & 2.7657 & 0.0007 \\
\hline 1 & 1 & 2 & 2.5460 & 2.5439 & 0.0021 \\
\hline-1 & 5 & 1 & 2.4148 & 2.4183 & -0.0035 \\
\hline-2 & 0 & 3 & 2.3727 & 2.3705 & 0.0022 \\
\hline-1 & 1 & 3 & 2.3196 & 2.3205 & -0.0009 \\
\hline 0 & 6 & 0 & 2.1703 & 2.1690 & 0.0013 \\
\hline 2 & 4 & 1 & 2.1199 & 2.1197 & 0.0002 \\
\hline \multicolumn{4}{|c|}{$\begin{array}{l}\text { Unit Cell Par. }^{\text {obs }} \\
a=8.4884 \AA \\
b=13.0038 \AA \\
c=7.1753 \AA \\
\beta=115.96^{\circ} \\
V=712.084 \AA^{3}\end{array}$} & \multicolumn{2}{|c|}{$\begin{array}{l}\text { Unit Cell Par.[160] } \\
a=8.562 \AA \\
b=12.996 \AA \\
c=7.193 \AA \\
\beta=116.016^{\circ} \\
V=719.28 \AA^{3} \\
Z=4 \\
\text { Monoclinic }(C 2 / m)\end{array}$} \\
\hline
\end{tabular}

Table 15

The most intense maxima from the X-ray powder diagram of the studied stilbite mineral used to calculate the unit cell parameters

\begin{tabular}{cccccc}
\hline \hline $\boldsymbol{h}$ & $\boldsymbol{k}$ & $\boldsymbol{l}$ & $\boldsymbol{d}_{\text {obs }}$ & \multicolumn{1}{c}{$\boldsymbol{d}_{\text {cal }}$} & $\boldsymbol{d}_{\text {diff }}$ \\
\hline 0 & 2 & 0 & 9.0991 & 9.1166 & -0.0175 \\
0 & 0 & 1 & 8.8804 & 8.8891 & -0.0087 \\
-2 & 0 & 1 & 6.8098 & 6.8122 & -0.0024 \\
-2 & 2 & 1 & 5.4578 & 5.4570 & 0.0008 \\
-2 & 0 & 2 & 5.4411 & 5.4427 & -0.0016 \\
-2 & 0 & 0 & 5.3723 & 5.3720 & 0.0003 \\
-1 & 3 & 1 & 5.3084 & 5.3066 & 0.0018 \\
-1 & 3 & 0 & 5.2896 & 5.2900 & -0.0004 \\
-1 & 1 & 2 & 5.2307 & 5.2317 & -0.0010 \\
-2 & 2 & 2 & 4.6732 & 4.6732 & 0.0000 \\
-2 & 2 & 0 & 4.6297 & 4.6283 & 0.0014 \\
0 & 4 & 0 & 4.5590 & 4.5583 & 0.0007 \\
0 & 0 & 2 & 4.4460 & 4.4445 & 0.0015 \\
-3 & 1 & 2 & 4.2929 & 4.2905 & 0.0024 \\
-3 & 1 & 1 & 4.2623 & 4.2643 & -0.0020 \\
-1 & 3 & 2 & 4.0620 & 4.0623 & -0.0003 \\
0 & 4 & 1 & 4.0565 & 4.0561 & 0.0004 \\
\hline Unit Cell Par. ${ }^{\text {obs }}$ & & Unit Cell Par.[161] \\
$a=13.6152 \AA$ & & $a=13.6234 \AA$ \\
$b=18.2192 \AA$ & & $b=18.2421 \AA$ \\
$c=11.2646 \AA$ & & $c=11.2793 \AA$ \\
$\beta=127.95^{\circ}$ & & & $\beta=127.978{ }^{\circ}$ \\
$V=2203.327 \AA$ & $\AA^{3}$ & & $V=2209.5 \AA^{3}$ \\
& & & & $Z=1$ & Monoclinic $(C 2 / m)$ \\
\hline \hline
\end{tabular}




\section{CONCLUSIONS}

\section{Cyclosilicates}

For the study of schorl (tourmaline) and beryl cyclosilicate minerals it could be concluded that the first evidence of beryl presence in the territory of $\mathrm{R}$. Macedonia was confirmed by vibrational spectroscopy and XRPD. Although beryl is a nominally anhydrous mineral, the obtained results strongly confirm the presence of $\mathrm{H}_{2} \mathrm{O}$ type II molecules in the structural channels. On the other hand, the Raman and especially the infrared $\mathrm{OH}$ spectral picture of the tourmaline variety was indicative to conclude a dominant presence of $\mathrm{Mg}$ and $\mathrm{Fe}$ cations in the $\mathrm{Y}$ structural sites, recognizing the studied mineral as the schorl variety (confirmed by XRPD). The appearance of a new band in the infrared $\mathrm{OH}$ stretching region at $3679 \mathrm{~cm}^{-1}$ was attributed to cation arrangement involving both $\mathrm{Mg}^{\mathrm{Y}} \mathrm{Fe}^{\mathrm{Y}} \mathrm{Fe}^{\mathrm{Y}}$ and $\mathrm{Mg}^{\mathrm{Y}} \mathrm{Mg}^{\mathrm{Y}} \mathrm{Fe}^{\mathrm{Y}}$ combinations.

\section{Phyllosilicates}

It could be concluded that, in general, vibrational spectroscopy gives preliminary, but very significant, information about several geologically important phyllosilicates and could be a vital tool for preliminary identification of the studied sheet silicate minerals collected from the Republic of Macedonia. It was also found that vibrational techniques could distinguish between the isomorphous chrysotile and antigorite, whereas IR spectroscopy provides discrimination of the hydroxide from water-containing minerals.

The recorded Raman spectra for the studied minerals (chrysotile and cymrite) with different excitation lasers confirmed the reproducibility of this technique. An attempt was made to interpret the IR and Raman spectra of cymrite based on analogy with the band assignment in the corresponding spectra of other sheet silicates (due to their common structural features). The sharp bands in the vibrational spectra of talc provide information for a high degree of structural order in this mineral. In two studied minerals, cymrite and montmorillonite, the presence of a sharp band due to $\delta(\mathrm{H}-\mathrm{O}-\mathrm{H})$ mode enables us to conclude that water molecules are present in their structures.

It should be pointed out that vibrational spectroscopy can not enable quick and simple discrimination of mica minerals adopting diverse chemical substitution and complicated crystal structure. Additional difficulties might introduce the presence of impurities into the mineral sam- ples. Therefore, their identification should not be based on morphological and vibrational spectroscopy features that could sometimes lead to improper identification (muscovite from Nežilovo was wrongly designated as paragonite). In this context, the results from the XRPD and chemical analysis should be additionally taken into account for correct characterization.

Some difficulties that appear in the identification process mainly arise from the presence of impurities in the minerals. Thereby it could be concluded that here Raman overpowers IR spectroscopy and enables differentiation between isomorphous calcite and dolomite impurities. The broader bands in the IR spectra could not be used to distinguish between the mentioned impurities of the isomorphous carbonates.

\section{Tectosilicates}

The study of albite, microcline, sanidine and stilbite has shown that vibrational spectroscopy gives preliminary, but very significant, information about the $\mathrm{Al} / \mathrm{Si}$ disorder effects in the alkali feldspars. It is mainly expressed by band broadening as well as by band number decrease in the IR and Raman spectra of the disordered sanidine compared to the corresponding spectra of the ordered microcline and albite.

Although differences are also observed in the $\mathrm{Si}(\mathrm{Al}) \mathrm{AO}$ spectral region, the most discriminating features among the alkali feldspars appear below $350 \mathrm{~cm}^{-1}$ (especially in the far-IR spectra) where $\mathrm{M}-\mathrm{O}$ vibrational bands occur. Namely, the effect of the chemical composition on band profiles enables very good correlation between $\mathrm{M}-\mathrm{O}$ vibrations ( $\mathrm{M}$ $=\mathrm{Na}$ and $/$ or $\mathrm{K}$ ) and cation mass difference.

Variation of the degree of sensitivity to impurities between both vibrational techniques justifies their simultaneous application, confirming their complementarity. However, difficulties in the identification process might appear, introduced by the impurities (in this case, carbonate) present in the analyzed specimen.

The results from the XRPD and chemical analysis were taken into account for their identification and proper characterization as well.

\section{REFERENCES}

[1] D. Bish, J. Post, Quantitative mineralogical analysis using the Rietveld full-pattern fitting method, Am. Mineral. 78, 932-940 (1993).

[2] D. Yu. Pushcharovsky, Recent Contributions and modem perspectives in XRD studies of minerals, Croat. Chem. Acta 73, 869-886 (2000). 
[3] V. C. Farmer (Ed.), The Infrared Spectra of Minerals, Mineralogical Society, London, 1974.

[4] P. F. McMillan, A. M. Hofmeister, Infrared and Raman Spectroscopy, in: F. C. Hawthorne, ed., Spectroscopic Methods in Mineralogy and Geology, Rev. Mineral., Mineral. Soc. Am., Blacksburg, VA, 18, 99-157 (1988).

[5] W. P. Griffith, Raman Spectroscopy of Minerals, in: V. C. Farmer (Ed.), The Infrared Spectra of Minerals, Mineralogical Society, London, 1974, pp. 119-135.

[6] I. Burgio, R. J. H. Clark, Library of FT-Raman spectra of pigments, minerals, pigment media and varnishes, and supplement to existing library of Raman spectra of pigments with visible excitation, Spectrochim. Acta, Part A 57, 1491-1521 (2001).

[7] S. J. Gaffey, Spectral reflectance of carbonate minerals in the visible and near infrared (0.35-2.55 microns): calcite, aragonite, and dolomite, Am. Mineral. 71, 151-162 (1986).

[8] A. E. Milodowski, D. J. Morgan, Identification and estimation of carbonate minerals at low levels by evolved $\mathrm{CO}_{2}$ analysis, Nature 286, 248-249 (1980).

[9] S. Yariv, Thermal analysis of minerals, Themochim. Acta 148, 421-430 (1989).

[10] Z. W. Zhang, F. X. Gan, Analysis of the chromite inclusions found in nephrite minerals obtained from different deposits using SEM-EDS and LRS, J. Raman Spectrosc. 42, 1808-1811 (2011).

[11] E. Akkas, L. Akin, H. E. Cubukcu, H. Artuner, Application of decision tree algorithm for classification and identification of natural minerals using SEM-EDS, Comput. Geosci. 80, 38-48 (2015).

[12] M. R. Lee, D. J. Brown, C. L. Smith, M. E. Hodson, M. Mackenzie, R. Hellmann, Characterization of mineral surfaces using FIB and TEM: A case study of naturally weathered alkali feldspars, Am. Mineral. 92, 1383-1394 (2007).

[13] T. J. Headley, R. C. Ewing, R. F. Haaker, Amorphous structure of metamict minerals observed by TEM, $\mathrm{Na}$ ture 293, 449-450 (1981).

[14] L. Ottolini, F. Camara, S. Bigi, An investigation of matrix effects in the analysis of fluorine in humitegroup minerals by EMPA, SIMS, and SREF, Am. Mineral. 85, 89-102 (2000).

[15] F. C. Hawthorne, M. Cooper, P. Bottazzi, L. Ottolini, T. C. Ercit, E. S. Grew, Microanalysis of minerals for boron by SREF, SIMS AND EMPA - A comparativestudy, Can. Mineral. 33, 389-397 (1995).

[16] G. Jovanovski, B. Boev, P. Makreski, M. Najdoski, G. Mladenovski, Minerals from Macedonia. XI. Silicate varieties and their localities - Identification by FT IR spectroscopy, Bull. Chem. Technol. Maced. 22, 111-141 (2003).

[17] G. Jovanovski, P. Makreski, B. Šoptrajanov, B. Kaitner, B. Boev, Minerals from Macedonia. Complementary use of vibrational spectroscopy and X-ray powder diffraction for identification and detection purposes, Contributions, Sec. Math. Tech. Sci., MASA 26, 7-84 (2005).

[18] G. Jovanovski, P. Makreski, B. Kaitner, B. Šoptrajanov, Minerals from Macedonia. X-ray powder diffraction vs. vibrational spectroscopy in mineral identification, Contributions, Sec. Math. Tech. Sci., MASA 30, 7-34 (2009).

[19] G. Jovanovski, P. Makreski, B. Kaitner, B. Boev, Silicate minerals from Macedonia. Complementary use of vibrational spectroscopy and X-ray powder diffraction for identification and detection purposes, Croat. Chem. Acta 82, 363-386 (2009); Erratum: Croat. Chem. Acta 85, CCXI-CCXIII (2012).

[20] G. Jovanovski, B. Boev. P. Makreski, Minerals from the Republic of Macedonia with an Introduction to Mineralogy, Macedonian Academy of Sciences and Arts, Skopje, 2012.

[21] P. Makreski, G. Jovanovski, B. Kaitner, T. Stafilov, B. Boev, Minerals from Macedonia. X. Separation and identification of some oxide minerals by FT IR spectroscopy, AAS, AES-ICP and powder XRD, N. Jb. Miner. Abh. 180, 215-243 (2004).

[22] P. Makreski, G. Jovanovski, S. Stojančevska, Minerlas from Macedonia. XIII. Vibrational spectra of some commonly appearing nesosilicate minerals, J. Mol. Struct. 744-747, 79-92 (2005).

[23] P. Makreski, G. Jovanovski, A. Gajović, Minerals from Macedonia. XVII. Vibrational spectra of some common appearing amphiboles, Vib. Spectrosc. 40, 98-109 (2006).

[24] P. Makreski, G. Jovanovski, Minerals from Macedonia. XXII. Laser-induced fluorescence bands in the FTRaman spectrum of almandine mineral, J. Raman Spectrosc. 39, 1210-1213 (2008).

[25] GRAMS32 for Microsoft Windows, Vers. 4.10, Galactic Industries Corporation, 1991-1996.

[26] R. Shirley, The CRYSFIRE System for Automatic Powder Indexing. (http://www.ccp14.ac.uk/tutorial/crys/).

[27] J. Laugier and B. Bochu, LMGP-Suite Suite of programs for the interpretation of X-ray experiments, ENSP/Laboratorie des Matériaux et du Génie Physique, BP 46. 38042 Saint Martin d'Hères, France. (http://www.inpg.fr/LMGP and http://www.ccp14.ac.uk./tutorial/lmgp/).

[28] http://www.webmineral.com/

[29] T. Ito, R. Sadanaga, A Fourier analysis of the structure of tourmaline, Acta Crystallogr. 4, 385-390 (1951).

[30] F. C. Hawthorne, D. J. MacDonald, P. C. Burns, Reassignment of cation site occupancies in tourmaline: Al$\mathrm{Mg}$ disorder in the crystal structure of dravite, Am. Mineral. 78, 265-270 (1993).

[31] C. Castaneda, E. F. Oliveira, N. Gomes, A. C. P. Soares, Infrared study of $\mathrm{OH}$ sites in tourmaline from the elbaite-schorl series, Am. Mineral. 85, 1503-1507 (2000).

[32] P. Keller, E. R. Robles, A. P. Perez, F. Fontan, Chemistry, paragenesis and significance of tourmaline in pegmatites of the Southern Tin Belt, central Namibia, Chem. Geol. 158, 203-225 (1999).

[33] B. Gasharova, B. Mihailova, L. Konstantinov, Raman spectra of various types of tourmaline, Eur. J. Mineral. 9, 935-940 (1997).

[34] A.Pieczka, Modelling of some structural parameters of tourmalines on the basis of their chemical composition. 
I. Ordered structure model, Eur. J. Mineral. 12, 589-596 (2000).

[35] K. A. Hughes, J. M. Hughes, M. D. Dyar, Chemical and structural evidence for ${ }^{[4]} \mathrm{B} \leftrightarrow{ }^{[4]} \mathrm{Si}$ substitution in natural tourmalines, Eur. J. Mineral. 13, 743-747 (2001).

[36] F. C. Hawthorne, D. J. Hendry, Classification of the minerals of the tourmaline group, Eur. J. Mineral. 11, 201-215 (1999).

[37] M. J. Buerger, C. W. Burnham, D. R. Peacor, Assessment of the several structures proposed for tourmaline, Acta Crystallogr. 15, 583-590 (1962).

[38] C. T. Gonzales-Carreno, M. Fernandez, J. Sanz, Infrared and electron microprobe analysis of tourmalines, Phys. Chem. Miner. 15, 452-460 (1988).

[39] F. F. Foit Jr., P. E. Rosenberg, Coupled substitutions in the tourmaline group, Contrib. Mineral. Petrol. 62, 109127 (1977)

[40] F. F. Foit, Jr., Crystal chemistry of alkali-deficient schorl and tourmaline structural relationships, Am. Mineral. 74, 422-431 (1989).

[41] A. Ertl, J. M. Hughes, S. Prowatke, G. R. Rossman, D. London, E. A. Fritz, Mn-rich tourmaline from Austria: structure, chemistry, optical spectra, and relations to synthetic solid solutions. Am. Mineral. 88, 1369-1376 (2003).

[42] A. Ertl, J. M. Hughes, S. Prowatke, T. Ludwig, P. S. R. Prasad, F. Brandstätter, W. Körner, R. Schuster, F. Pertlik, H. Marschall, Tetrahedrally-coordinated boron in tourmalines from the liddicoatite-elbaite series from Madagascar: Structure, chemistry, and infrared spectroscopic studies. Am. Mineral. 91, 1847-1856 (2006).

[43] A. Ertl, U. Kolitsch, S. Prowatke, M. D. Dyar, D. J. Henry, The F-analogue of schorl from Grasstein, Trentino - South Tyrol, Italy: crystal structure and chemistry. Eur. J. Mineral. 18, 583-588 (2006).

[44] A. Ertl, G. R. Rossman, J. M. Hughes, D. London, Y. Wang, J. A. O'Leary, M. D. Dyar, S. Prowatke, T. Ludwig, E. Tillmanns, Tourmaline of the elbaite-schorl series from the Himalaya Mine, Mesa Grande, California U.S.A.: A detailed investigation. Am. Mineral. 95, 24 40 (2010).

[45] A. Ertl, E. Tillmanns, The [9]-coordinated X site in the crystal structure of tourmaline-group minerals. Z. Kristallogr. 227, 456-459 (2012).

[46] A. Ertl, U. Kolitsch, M. D. Dyar, J. M. Hughes, G. R. Rossman, A. Pieczka, D. J. Henry, F. Pezzotta, S. Prowatke, C. L. Lengauer, W. Körner, F. Brandstätter, C. A. Francis, M. Prem, E. Tillmanns, Limitations of $\mathrm{Fe}^{2+}$ and $\mathrm{Mn}^{2+}$ site occupancy in tourmaline: evidence from $\mathrm{Fe}^{2+}$ - and $\mathrm{Mn}^{2+}$-rich tourmaline, Am. Mineral. 97, 1402-1416 (2012).

[47] A. Ertl, G. Giester, U. Schüssler, H. Brätz, M. Okrusch, E. Tillmanns, $\mathrm{H}$. Bank, $\mathrm{Cu}$ - and Mn-bearing tourmalines from Brazil and Mozambique: Crystal structures, chemistry and correlations. Mineral. Petrol. 107, 265-279 (2013).

[48] W. P. Griffith, Raman studies on rock-forming minerals. Part I. Orthosilicates and cyclosilicates, J. Chem. Soc. A, 1372-1377 (1969).
[49] M. A. Alvarez, R. Coy-Yll, Raman spectra of tourmaline, Spectrochim. Acta, Part A 34, 899-908 (1978)

[50] M. Peng, H.-K. Mao, L. G. Chen, E. E. T. Chan, Ann. Rep. of the Director of the Geophysical Laboratory, Carnegie Inst. Washington, Geophysical Laboratory, Washington, DC, 1988-1989, pp. 99-105.

[51] A. Ertl, U. Kolitsch, M. D. Dyar. H.-P. Meyer, G. R. Rossman, D. J. Henry, M. Prem, T. Ludwig, L. Nasdala, C. L. Lengauer, E. Tillmanns, G. Niedermayer, Fluorschorl, a new member of the tourmaline supergroup, and new data on schorl from the cotype localities, Eur. J. Mineral. 28, 163-177 (2016).

[52] A. Aurisicchio, O. Grubessi, P. Zecchini, Infrared spectroscopy and crystal chemistry of the beryl group, Can Mineral. 32, 55-68 (1994).

[53] R. D. Aines, G. R. Rossman, The high temperature behavior of water and carbon dioxide in cordierite and beryl, Am. Mineral. 69, 319-327 (1984).

[54] D. L. Wood, K. Nassau, The characterization of beryl and emerald by visible and infrared absorption spectroscopy, Am. Mineral. 53, 777-800 (1968).

[55] D. L. Wood, K. Nassau, Infrared spectra of foreign molecules in beryl, J. Chem. Phys. 47, 2220-2228 (1967).

[56] R. I. Mashkovtsev, A. S. Lebedev, Infrared spectroscopy of water in beryl, Zh. Strukt. Khim. 33, 930-933 (1992).

[57] D. M. Adams, I. R. Gardner, Single-crystal vibrational spectra of apatite, vanadinite, and mimetite, J. Chem. Soc., Dalton Trans. 74, 1502-1505 (1974).

[58] A. M. Hofmeister, T. C. Hoering, D. Virgo, Vibrational spectroscopy of beryllium aluminosilicates: Heat capacity calculations from band assignments, Phys. Chem. Miner. 14, 205-224 (1987).

[59] B. Charoy, P. De Donato, O. Barres, C. Pinto-Coelho, Channel occupancy in an alkali-poor beryl from Serra Branca (Goias, Brazil): Spectroscopic characterization, Am. Mineral. 81, 395-403 (1996)

[60] M. Lodzinski, M. Sitarz, K. Stec, M. Kozanecki, Z. Fojud, S. Jurga, ICP, IR, Raman, NMR investigations of beryls from pegmatites of the Sudety Mts, J. Mol. Struct. 744-747, 1005-1015 (2005).

[61] J. T. Kloprogge, R. L. Frost, Raman microscopic study at 300 and $77 \mathrm{~K}$ of some pegmatite minerals from the Iveland-Evje area, Aust-Agder, Southern Norway, Spectrochim. Acta, Part A, 56, 501-513 (2000).

[62] H. Hagemann, A. Lucken, H. Bill, J. Gysler-Sanz, H. A. Stadler, Polarized Raman spectra of beryl and bazzite, Phys. Chem. Miner. 17, 395-401 (1990).

[63] B. A. Kolesov, C. A. Geiger, The orientation and vibrational states of $\mathrm{H}_{2} \mathrm{O}$ in synthetic alkali-free beryl, Phys. Chem. Miner. 27, 557-564 (2000).

[64] B. A. Kolesov, Raman spectra of single $\mathrm{H}_{2} \mathrm{O}$ molecules isolated in cavities of crystals, J. Struct. Chem. 47, 2134 (2006).

[65] P. Makreski, G. Jovanovski, Minerals from Macedonia. XXIII. Spectroscopic and structural characterization of schorl and beryl cyclosilicates, Spectrochim. Acta, Part A, 73, 460-467 (2009). 
[66] V. Šontevska, G. Jovanovski, P. Makreski, Minerals from Macedonia. XIX. Vibrational spectroscopy as identificational tool for some sheet silicate minerals, $\mathrm{J}$. Mol. Struct. 834-836, 318-327 (2007).

[67] M. J. Harris, E. K. H. Salje, B. K. Guttler, M. A. Carpenter, Structural states of natural potassium feldspar: An infrared spectroscopic study, Phys. Chem. Miner. 16, 649-658 (1989).

[68] T. P. Mernagh, Use of the laser Raman microprobe for discrimination amongst feldspar minerals, J. Raman Spectrosc. 22, 453-457 (1991).

[69] F. F. Foit Jr., X-ray and Optical Data for a Vanadiumrich Dravite from Silver Knob, Mariposa County, California, U.S.A., Powder Diffr. 7, 236-238 (1992).

[70] E. S. Bloodaxe, J. M. Hughes, M. D. Dyar, E. S Grew, C. V. Guidotti, Linking structure and chemistry in the schorl-dravite series, Am. Mineral. 84, 922-928 (1999).

[71] C. Aurisicchio, G. Fioravanti, O. Grubessi, P. F. Zanazzi, Reappraisal of the crystal chemistry of beryl, Am. Mineral. 73, 826-837 (1988).

[72] W. D. Nesse, Introduction to Mineralogy, Oxford University Press, New York, 2000.

[73] A. Wang, J. Han, L. Guo, J. Yu, P. Zeng, Database of standard Raman spectra of minerals and related inorganic crystals, Appl. Spectrosc. 48, 959-968 (1994).

[74] G. R. Hunt, J. W. Salisbury, C. J. Lenhoff, Visible and near infrared spectra of minerals and rocks. VI. Additional silicates, Mod. Geol. 4, 85-106 (1973).

[75] E. Huang, C. H. Chen, T. Huang, E. H. Lin, J.-A. Xu, Raman spectroscopic characteristics of $\mathrm{Mg}-\mathrm{Fe}-\mathrm{Ca}$ pyroxenes, Am. Mineral. 85, 473-479 (2000).

[76] P. Makreski, G. Jovanovski, A. Gajović, T. Biljan, D. Angelovski, R. Jaćimović, Minerals from Macedonia. XVI. Vibrational spectra of some common appearing pyroxenes and pyroxenoids, J. Mol. Struct. 788, 102114 (2006)

[77] C. Viti, M. Mellini, Contrasting chemical compositions in associated lizardite and chrysotile in veins from Elba, Italy, Eur. J. Mineral. 9, 585-596 (1997).

[78] D. G. Taylor, C. M. Nenadić, J. V. Crable, Infrared spectra for mineral identification, Amer. Ind. Hyg. Ass. J., 31, 100-108 (1970).

[79] V. C. Farmer (Ed.), The Infrared Spectra of Minerals, Mineralogical Society, London, 1974, pp. 331-358.

[80] E. Foresti, M. Gazzano, A. F. Gualteiri, I. G. Lesci, B. Lunelli, G. Pecchini, E. Renna, N. Roveri, Determination of low levels of free fibres of chrysotile in contaminated soils by X-ray diffraction and FTIR spectroscopy, Anal. Bioanal. Chem. 376, 653-658 (2003).

[81] V. Stubičan, R. Roy, Isomorphous substitution and infra-red spectra of the layer lattice silicates, Am. Mineral. 46, 32-51 (1961).

[82] M. Mellini, Y. Fuchs, C. Viti, C. Lemaire, J. Linares, Insights into the antigorite structure from Mössbauer and FTIR spectroscopies, Eur. J. Mineral. 14, 97-104 (2002).

[83] NICODOM, Inorganic Library of FTIR Spectra - Minerals, 1998.
[84] J. D. Russell, V. C. Farmer, B. Velde, Replacement of $\mathrm{OH}$ by $\mathrm{OD}$ in layer silicates, and identification of the vibrations of these groups in infra-red spectra, Mineral. Mag. 37, 869-879 (1970).

[85] K. Smolander, A. Saastamoinen, M. Ahlgren, Determination of talc in geological samples by infrared spectrometry, Anal. Chim. Acta 217, 353-358 (1989).

[86] W. Vedder, Correlations between infrared spectrum and chemical composition of mica, Am. Mineral. 49, 736768 (1964).

[87] N. O. Gopal, K. V. Narasimhulu, J. L. Rao, Optical absorption, EPR, infrared and Raman spectral studies of clinochlore mineral, J. Phys. Chem. Solids, 65, 18871893 (2004).

[88] A. C. Prieto, J. Dubessy, M. Cathelineau, StructureComposition Relationships in Trioctahedral Chlorites: A Vibrational Spectroscopy Study, Clay Clay Miner. 39, 531-539 (1991).

[89] C. M. Graham, J. A. K. Tareen, P. F. McMillan, B. M. Lowe, An experimental and thermodynamic study of cymrite and celsian stability in the system $\mathrm{BaO}-\mathrm{Al}_{2} \mathrm{O}_{3}-$ $\mathrm{SiO}_{2}-\mathrm{H}_{2} \mathrm{O}$, Eur. J. Mineral. 4, 251-269 (1992).

[90] V. C. Farmer, J. D. Russell, The infra-red spectra of layer silicates, Spectrochim. Acta, 20, 1149 (1964).

[91] C. Rinaudo, D. Gastaldi, E. Belluso, Characterization of chrysotile, antigorite and lizardite by FT-Raman spectroscopy, Can. Mineral. 41, 883-890 (2003).

[92] J. T. Kloprogge, R. L. Frost, L. Rintoul, Single crystal Raman microscopic study of the asbestos mineral chrysotile, Phys. Chem. Chem. Phys. 1, 2559-2564 (1999).

[93] J. J. Blaha, G. J. Rosasco, Raman microprobe spectra of individual microcrystals and fibers of talc, tremolite, and related silicate minerals, Anal. Chem. 50, 892-896 (1978).

[94] A. K. Kleppe, A. P. Jephcoat, M. D. Welch, The effect of pressure upon hydrogen bonding in chlorite: A Raman spectroscopic study of clinochlore to $26.5 \mathrm{GPa}, \mathrm{Am}$. Mineral. 88, 567-573 (2003).

[95] R. L. Frost, L. Rintoul, Lattice vibrations of montmorillonite: a FT Raman and X-ray diffraction study, Appl. Clay Sci. 11, 171-183 (1996).

[96] W. Vedder, R. S. McDonald, Vibrations of $\mathrm{OH}$ ions in muscovite, J. Chem. Phys. 38, 1583-1590 (1963).

[97] M. V. Zeller, M. P. Juszli: Infrarot-Vergleichsspektren von Mineralien. Angewandte Infrarotspektroskopie, Heft 16, Bodenseewerk Perkin-Elmer \& Co GmbH, Überlingen, 1975.

[98] http://www.fdmspectra.com/

[99] N. Wada, W. A. Kamitakahara, Inelastic neutron- and Raman-scattering studies of muscovite and vermiculite layered silicates, Phys. Rev. Part B, 43, 2391-2397 (1991).

[100] D. A. McKeown, M. I. Bell, E. S. Etz, Vibrational analysis of the dioctahedral mica: 2M1 muscovite, Am. Mineral. 84, 1041-1048 (1999)

[101] B. Wopenka, R. Popelka, J. D. Pasteris, S. Rotroff, Understanding the Mineralogical Composition of Ancient Greek Pottery through Raman Microprobe Spectroscopy, Appl. Spectrosc. 56, 1320-1328 (2002). 
[102] K. Langer, N. D. Chatterjee, K. Abraham, Infrared studies of some synthetic and natural $2 \mathrm{~m} 1$ dioctahedral micas, N. Jb. Min. Abh. 142, 91-110 (1981).

[103] A. Beran, Infrared spectroscopy of micas, Rev. Mineral. Geochem. 46, 351-369 (2002).

[104] A. Papin, J. Sergent, J. L. Robert, Intersite OH-F distribution in an Al-rich synthetic phlogopite, Eur. J. Mineral. 9, 501-508 (1997).

[105] D. A. McKeown, M. I. Bell, E. S. Etz, Raman spectra and vibrational analysis of the trioctahedral mica phlogopite, Am. Mineral. 84, 970-976 (1999).

[106] D. M. Jenkins, Empirical study of the infrared lattice vibrations (1100-350 $\left.\mathrm{cm}^{-1}\right)$ of phlogopite, Phys. Chem. Miner. 16, 408-414 (1989).

[107] http://www.fis.unipr.it/phevix/ramandb.html

[108] http://wwwobs.univ-bpclermont.fr/sfmc/ramandb2/index.html

[109] V. Šontevska, G. Jovanovski, P. Makreski, A. Raškovska, B. Šoptrajanov, Minerals from Macedonia. XXI. Vibrational spectroscopy as identificational tool for some phyllosilicate minerals, Acta Chim. Slov. 55, 757766 (2008).

[110] D. Slovenec and V. Bermanec, Sistematska mineralogija - Mineralogija silikata, Denona d.o.o., Zagreb, 2003.

[111] V. C. Farmer, in: V .C. Farmer (Ed.): The Infrared Spectra of Minerals, Mineralogical Society, London, 1974, pp. 331-358.

[112] G. Jovanovski, V. Stefov, B. Šoptrajanov, B. Boev, Minerals from Macedonia. IV. Discrimination between some carbonate minerals by FTIR spectroscopy, $N$. $J b$. Miner. Abh. 177, 241-253 (2002).

[113] O. H. Erdmannsdöffer, Über Kossmatite, ein neues Gleid der Sprödglimmergruppe und seine Paragenese, Cbl. Miner. Geol. Paläont., Abt. A, 69-72 (1925).

[114] Lj. Barić, Dolomitmarmor in der Umgebung der Stadt Prilep und die in ihm vorkommenden Minerale, Tschermaks Miner. Petrogr. Mitt. 13, 233-249 (1969).

[115] H. Strunz, E. H. Nickel, Strunz Mineralogical Tables (Ninth Ed): Chemical Structural Mineral Classification System, Schweizerbart'sche Verlagsbuchhandlung, Germany, 2001.

[116] E. J. W. Whittaker, The structure of chrysotile, II. Clinochrysotile, Acta Crystallogr. 9, 855-862 (1956).

[117] G. Capitani, M. Mellini, The modulated crystal structure of antigorite, Am. Mineral. 89, 147-158 (2004).

[118] J. W. Gruner, The crystal structures of talc and pyrophyllite, Z. Kristallogr. 88, 412-419 (1934)

[119] R. C. McMurchy, The crystal structure of the chlorite minerals, Z. Kristallogr. 88, 420-432 (1934).

[120] V. A. Drits, A. A. Kashaev, G. V. Sokolova, Crystal structure of cymrite, Sov. Phys. Crystallogr. 20, 280286 (1975).

[121] S. Guggenheim, Y. H. Chang, A. F. Koster van Groos, Muscovite dehydroxylation: High-temperature studies, Am. Mineral. 72, 537-550 (1987).
[122] A. Laurora, M. F. Brigatti, A. Mottana, D. Malferrari, E. Caprilli, Crystal chemistry of trioctahedral micas in alkaline and subalkaline volcanic rocks: A case study from Mt. Sassetto (Tolfa district, Latium, central Italy), Am. Mineral. 92, 468-480 (2007).

[123] S. B. Hendricks, M. E. Jefferson, Polymorphism of the micas with optical measurements, Am. Mineral. 24, (1939) 729-771.

[124] P. Makreski, G. Jovanovski, B. Kaitner, A. Gajović , T. Biljan, Minerals from Macedonia: XVIII. Vibrational spectra of some sorosilicates, Vib. Spectrosc. 44, 162 170 (2007).

[125] P. Makreski, G. Jovanovski, Minerals from Macedonia. XXII. Laser-induced fluorescence bands in the FTRaman spectrum of almandine mineral, J. Raman Spectrosc. 39, 1210-1213 (2008).

[126] P. Makreski, T. Runčevski, G. Jovanovski, Minerals from Macedonia. XXVI. Characterization and spectrastructure correlations for grossular and uvarovite. Raman study supported by IR spectroscopy, J. Raman Spectrosc. 42, 72-77 (2011).

[127] H. Moenke, Mineralspektren, I. Akademie-Verlag, Berlin, 1962.

[128] H. Moenke, Mineralspektren, II. Akademie-Verlag, Berlin, 1966.

[129] E. A. Johnson, G. R. Rossman, The concentration and speciation of hydrogen in feldspars using FTIR and $1 \mathrm{H}$ MAS NMR spectroscopy, Am. Mineral. 88, 901-911 (2003).

[130] R. Couty, B. Velde, Pressure-induced band splitting in infrared spectra of sanidine and albite, Am. Mineral. 71, 99-104 (1986).

[131] B. Wyncke, P. F. McMillan, W. L. Brown, R. E. Openshaw, F. Brehat, A room-temperature phase transition in maximum microcline. Absorption in the far infrared $\left(10-200 \mathrm{~cm}^{-1}\right)$ in the temperature range $110-300 \mathrm{~K}$, Phys. Chem. Miner. 7, 31-34 (1981).

[132] H. Behrens, G. Muller, An infrared spectroscopic study of hydrogen feldspar $\left(\mathrm{HA}_{1} \mathrm{Si}_{3} \mathrm{O}_{8}\right)$ Mineral. Mag. 59, 1524 (1995).

[133] K. Harada, K. Tomita, A sodian stilbite from Onigajo, Mié Prefecture, Japan, with some experimental studies concerning the conversion of stilbite to wairakite at low water vapor pressures, Am. Mineral. 52, 1438-1450 (1967).

[134] M. W. Kasture, S. P. Mirajkar, V. V. Joshi, A. L. Choudhari, V. P. Shiralkar, Thermal behaviour and adsorption properties of natural stilbite, J. Incl. Phen. Mol. Recogn. Chem. 29, 1-13 (1997).

[135] P. S. R. Prasad, K. S. Prasad, S. R. Murthy, Dehydration of natural stilbite: An in situ FTIR study, Am. Mineral. 90, 1636-1640 (2005)

[136] M. Lodzinski， R. Wrzalik，M. Sitarz，Micro-Raman spectroscopy studies of some accessory minerals from pegmatites of the Sowie Mts and Strzegom-Sobótka massif, Lower Silesia, Poland, J. Mol. Struct. 744-747, 1017-1026 (2005). 
[137] W. Mozgawa, The relation between structure and vibrational spectra of natural zeolites, J. Mol. Struct. 596, 129-137 (2001).

[138] J. E. Dickinson Jr., C. M. Scarfe, Raman spectroscopic study of glasses on the join diopside-albite, Geochim. Cosmochim. Acta 54, 1037-1043 (1990).

[139] P. F. McMillan, S. Jakobsson, J. R. Holloway, L.A. Silver, A note on the Raman spectra of water-bearing albite glasses, Geochim. Cosmochim. Acta 47, 1937-1943 (1983).

[140] R. Gout, E. H. Oelkers, J. Schott, A. Zwick, Propagating errors in decay equations: Examples from the Re-Os isotopic system, Geochim. Cosmochim. Acta 61, 30133018 (1997).

[141] P. Frogner, C. Broman, S. Lindblom, Weathering detected by Raman spectroscopy using Al-ordering in albite, Chem. Geol. 151, 161-168 (1998).

[142] D. A. McKeown, Raman spectroscopy and vibrational analyses of albite: From $25{ }^{\circ} \mathrm{C}$ through the melting temperature, Am. Mineral. 90, 1506-1517 (2005).

[143] D. W. Matson, S. K. Sharma, J. A. Philpotts, Raman spectra of some tectosilicates and of glasses along the orthoclase-anorthite and nepheline-anorthite joins, Am. Mineral. 71, 694-704 (1986).

[144] S. E. J. Villar, H. G. M. Edwards, Near-infrared Raman spectra of terrestrial minerals: relevance for the remote analysis of Martian spectral signatures, Vib. Spectrosc. 39, 88-94 (2005).

[145] B. Velde, Y. Syono, M. Kikuchi, H. Boyer, Raman microprobe study of synthetic diaplectic plagioclase feldspars, Phys. Chem. Miner. 16, 436-441 (1989).

[146] B. Velde, H. Boyer, Raman microprobe spectra of naturally shocked microcline feldspars, J. Geophys. Res. 90, 3675-3682 (1985).

[147] P. Makreski, G. Jovanovski, B. Kaitner, Minerals from Macedonia. XXIV. Spectra-structure characterization of tectosilicates, J. Mol. Struct. 924-926, 413-419 (2009).

[148] E. K. H. Salje, B. Guttler, C. Ormerod, Determination of the degree of $\mathrm{Al}, \mathrm{Si}$ order $Q_{\text {od }}$ in kinetically disordered albite using hard mode infrared spectroscopy, Phys. Chem. Miner. 16, 576-581 (1989).
[149] M. Zhang, B. Wruck, A. Graeme-Barber, E. K. H. Salje, M. A. Carpenter, Phonon-spectroscopy on alkalifeldspars: Phase transitions and solid solutions, Am. Mineral. 81, 92-104 (1996).

[150] M. Handke, W. Mozgawa, Vibrational spectroscopy of the amorphous silicates, Vib. Spectrosc. 5, 75-84 (1993).

[151] K. Iiishi, T. Tomisaka, T. Kato, Y. Umegaki, Isomorphous substitution and infrared and far infrared spectra of the feldspar group, N. Jb. Miner. Abh. 115, 98-119 (1971).

[152] M. O. Stengel, Normalschwingungen von Alkalifeldspäten, Z. Kristallogr. 146, 1-18 (1977).

[153] M. Zhang, E. K. H. Salje, M. A. Carpenter, I. Parsons, H. Kroll, S. J. B. Reed, A. Graeme-Barber, Exsolution and Al-Si disorder in alkali feldspars: Their analysis by infrared spectroscopy, Am. Mineral. 82 (1997) 849-857.

[154] G. Jovanovski, V. Stefov, B. Šoptrajanov, B. Boev, Minerals from Macedonia. IV. Discrimination between some carbonate minerals by FTIR spectroscopy, $N$. $J b$. Miner. Abh. 177, 241-253 (2002).

[155] S. K. Sharma, J. A. Philpotts, D. N. Matson, Ring distributions in alkali- and alkaline-earth aluminosilicate framework glasses - a Raman spectroscopic study, $J$. Non-Cryst. Solids 71, 403-410 (1985).

[156] A. C. Lassaga, G. V. Gibbs, Quantum mechanical potential surfaces and calculations on minerals and molecular clusters, Phys. Chem. Miner. 16, 29-41 (1988).

[157] M. S. Joshi, V. V. Joshi, A. L. Choudhari, M. W. Kasture, Structural studies of natural heulandite using infrared spectroscopy, Mater. Chem. Phys. 48, 160-163 (1997).

[158] R. T. Downs, R. M. Hazen, L. W. Finger, The highpressure crystal chemistry of low albite and the origin of the pressure dependency of Al-Si ordering, Am. Mineral. 79, 1042-1052 (1994).

[159] D. R. Allan, R. J. Angel, A high-pressure structural study of microcline $\left(\mathrm{KAlSi}_{3} \mathrm{O}_{8}\right)$ to $7 \mathrm{GPa}$, Eur. J. Miner. 9, 263-275 (1997).

[160] M. W. Phillips, P. H. Ribbe, The structures of monoclinic potassium-rich feldspars, Am. Mineral. 58, 263-270 (1973).

[161] M. Slaughter, Crystal structure of stilbite, Am. Mineral. 55, 387-397 (1970). 